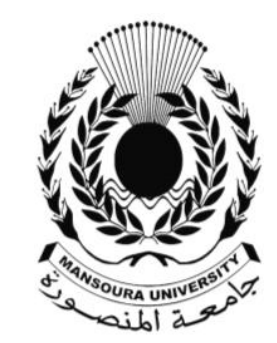

جامعة المنصـورة المين

$$
\text { كليـة الآداب }
$$

\title{
البلاغة العربية ورهانات الحداثة
}

\author{
إعـــ/د \\ دكتور / شكري الطوانسي \\ أستاذ مساعد البلاغة والنقد الأدبي \\ كلية آداب- جامعة الزقازيق
}

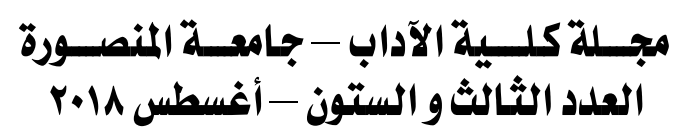




\section{البلا غة العربية وروهانات الهداثة}

\section{د. شكري عبدا لحميل أحمد الطوانسي}

يتساءل البحث عن الخيارات التي يمكن أن تكون أمام البلاغة العربية في هذا العصر الذي شهد ثورات علمية وتطورات هائلة في مختلف مجالات المعرفة، مها وضعها مرة أخرى أمام مصير محتوم، إما باستبدالها ببديل عصري كالأسلوبيات أو السييائيات، تكون اتجاهاً أو عنصراً

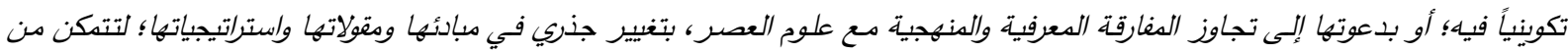
مجاورة التيارات الحديثة، فتنهض مكوناً فاعلاً في تأسيس علدي للدرس النقدي العربي، وتلبي متطلبات الحداثة، وقد قام البحث باختبار هذه

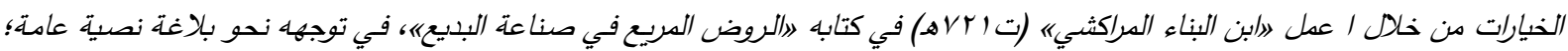

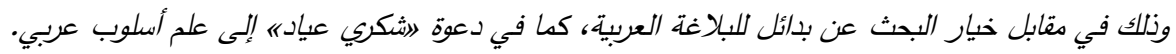

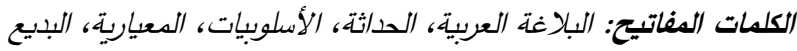

\section{Abstract}

The subject of this search for the options that can be in front of Arab rhetoric in this age, which witnessed scientific revolutions and huge developments in different fields of knowledge, which put it back to an inevitable fate, either replaced by a modern alternative such as stylistics or semiotics, in order to overcome the cognitive and methodological paradox with the sciences of the age, by radical changing its principles and strategies, so as to be able to contend with the modern currents. It is an active component in the scientific establishment of the arab critical inquiry. It meets the demands of modernity. The study examined these options through the work of Ibn al-Banna al-Marrakshi (d. $721 \mathrm{AH}$ ) which approaches to a general rhetorical eloquence, in contrast to the search for alternatives to arabic eloquence, as in which Shokry Ayyad calls: arabic stylistics.

Key Words: Arab rhetoric, modernity, stylistics, normative, badia

المعرفيـة وانفتاحهـا، ولا نهائيـة الأشـكال والصـيخ

المقدمــــ

والممارسات التعبيرية. ويمكن لمثل هذا التغيير في

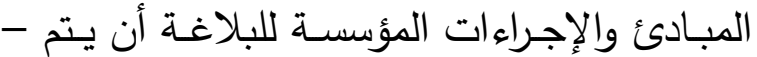
من بين عدد من الخيارات - عبر عملية تأويلية

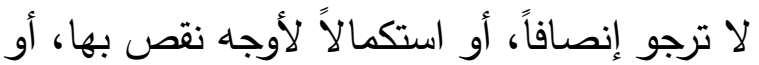

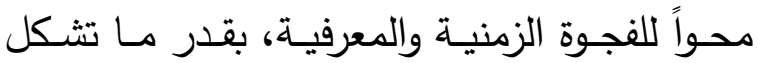
استعادة لما هو قابل للبقاء، وللتحول به إلى تراث

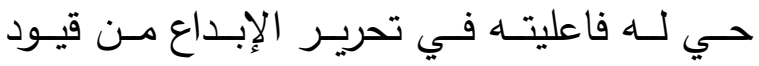
وتحكمـات تحـول دون تأسـيس جماليـات للتلقي تعتمــــــــاهيم الاخـتلاف والانفتــاح والإرجـاء، متجاوزة منطق التطابق والتوافق والتناسب الذي هيمن على البلاغـة القديمـة والكلاسيكية. وتمثل المؤلفات أو المشاريع البلاغية التي اختطت طريقاً

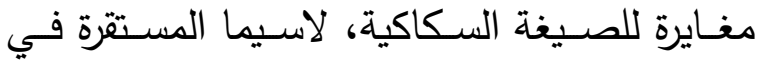

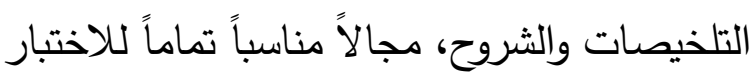

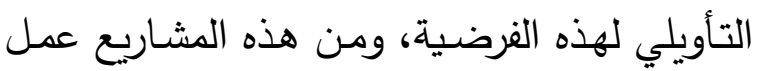

كان مـن الطبيعي مـع تطور العلم وتغير مفهومها، أن تجد البلاغة نفسها، في عصر شهر ثورات علمية وتطورات هائلة في مختلف مجالات المعرفـة، لاسيما ذات الصـلة المباشـرة بالبلاغـة، مثل اللسـانيات، والسيميائيات، والجماليات؛ تجد نفسـها مـرة أخـرى أمسام مصـير محتـوم، إمــا باستبدالها ببديل أو ممثل عصري كالأسلوبيات أو

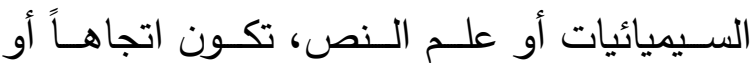
عنصــراً تكوينيـاً فيـه؛ أو بـدعوتها إلـى تجـاوز

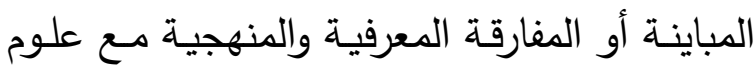
العصـر، بتغييـر جذري في مبادئهـا ومقولاتهـا واسـتراتيجياتها؛ لتـتمكن مسن مجــاورة التيــارات الحديثة، وخصوصـاً الأسلوبيات، فتنهض مكونـاً

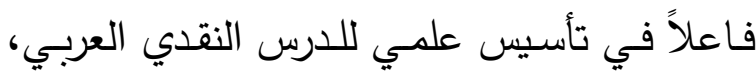
وتلبي متطلبات الحداثة، وتواكب تحولات الأنساق 
جزئية وتعسفية.

كانـت البلاغــة القديمـة، اليونانيـة والعربيـة

على السواء، علماً كلياً يتعلق بمبادئ عامـة لكل أنواع الخطابات أو الأقاويل، أو بأوضـاع نموذجية لئية

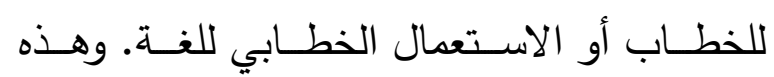
المبـادئ الكليـة أو الأوضـاع النموذجيـة، على الـى الـرغم مـن أن وضـعها وصـياغتها تـم في ظـل انشغال بخطاب نوعي خاص (خطابة، أو قرآن،

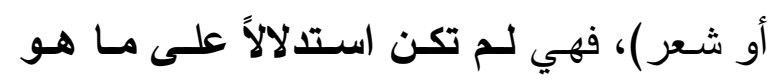

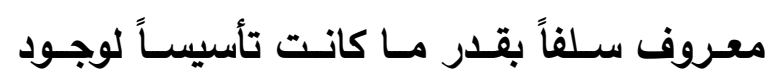
(محتمـل) للوقائع أو الظواهر أو الخطابـات، من غير التفات إلى شروط وجودها وتفسيره أو شرحه، فهو وجود/ محتمل متحلِّل أو منفلت من سياقاته

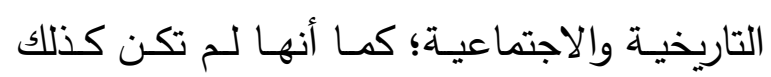
وليدة استقراء، فكل معاينة، كما يقول كارل بوبر K.R. Popper

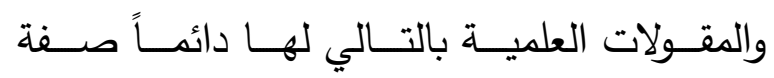

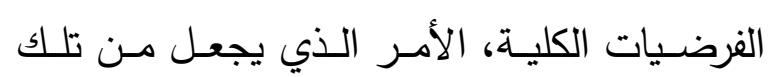

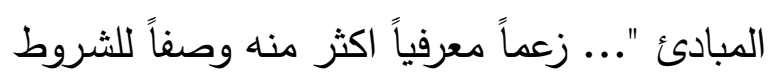
الوجودية."(1)، أي لعلة وجود الواقعة على ما هي عليه. وهكذا كان تعريف العلم عند العرب، فهو

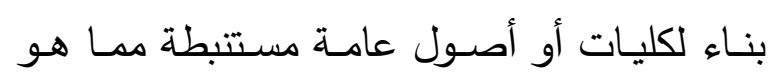
موجـود، تمكــن مــن إدراكــات جزئيــة، وتتـيح استحضارها، دون أن تحمل جديداً أو تقدم تفسيراً. إنه (أي العلم في التصور العربي) إدراك لما يكون إن أندان عليه الثيء، أو تصور الأمور على ما هي عليه، أو الموجود من حيث هو، أو هو الاعتقاد الجازم

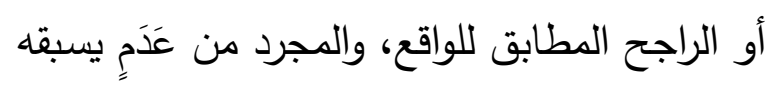

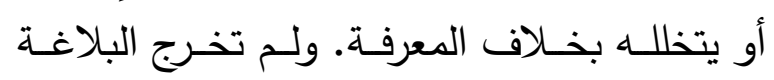

》ابـن البنـاء المراكثـي" (ت 721هـ) في كتابـه ״الروض المريع في صناعة البديع)، الذي يقترب فيه مما تطرحه البلاغة المعاصرة في توجهها نحو بلاغة نصية عامـة؛ وذلك في مقابل خيار البحث عن بدائل للبلاغة العربية، كما في دعوة اشكري عياده إلى علم أسلوب عربي.

\section{إشكاليات البلاغة العربية}

تعـد البلاغـة العربيـة واحـدة مـن منظومـة

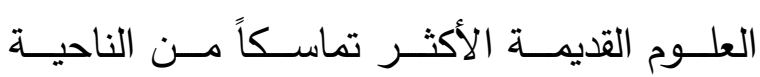
المنهجيـة، فقد كانــ دراســة نسـقية منظمــة للغــة ولطرق إنتاج الخطابـات والنصـوص، ممـا جعلها جديرة بتسمية العلم وفق مفهوم العلم القديم وقوانينه وشروطه. ويأتي نزوعها، شأنها شأن جملة العلوم

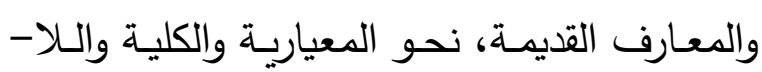
زمنيـة ضــن هذه الشـروط، انطلاقـاً مـن تصـور ميتافيزيقي ومنطقي للعالم بأشيائه وحقائقه، فكانت (أي البلاغـة)، في المجمـل، ولاسـيما في طورهـا

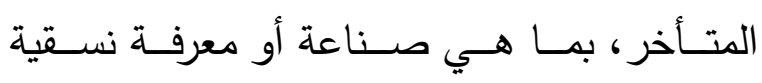

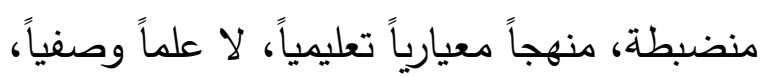

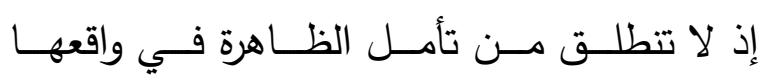
التاريخي، بـل تحتكم إلى معـايير عامـة منطقيـة وعقلية، ومفاهيم وتعريفات وتصنيفات قبلية، تمت صسياغتها من منظور اصطفائي أو انتقائي، فلم تكن وليدة رصد شامل وموضوعي، وتتبع لما يطرأ من تطور وتتوع في الاستخدامات والأشكال، وما

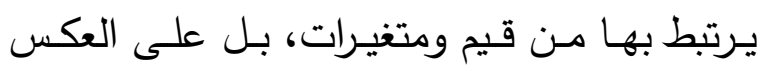
كانت تتعالى على مثل هذه الاستخدامات؛ كما أن

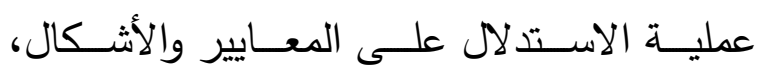
واختبارهـا وقيـاس صـــيتها، كانــت تـتم بطريقــة 
طاغية في الشرق والغرب ..."(4)، على نحو جعل النــزوع صـــوب النمذجـــة ووضــــع المعــايير والتصنيفات، والذي يـلازم العلم عبر تاريخـه في سـعيه نحـو فهم أعمق وأشــل للظـواهر - سـمة جوهريـة لكل البلاغـات والمعـارف القديمـة، تلـك التي كانت تفكر بحدود المنطق الصوري الشكلي، ومن داخل نسق مغلق، مكتفٍ بذاته، يحيل إلى ذاته فلا يحقق سوى معرفة بالذات، بما هي عليه، أو يطرح المعرفة الجزئية على أنها قوانين لمـا لها هو موجود وواقع أو محتمل. وهو مـا يصرح بـ جان كوهن Jean Cohen بخصوص البلاغـة الغربية، وسائر العلوم القديمـة، في قوله: "والواقع

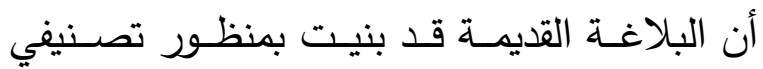
خالص. لقد وقفت محاولتها عند وضـع المعـالم، وتســمية وترتيــب الأصـــناف المختلفــة مـــن الانزياحسات. كانــت تلـك المهمـة مملـة، ولكنهــا ضـرورية، فمـن هنـا ابتدأت العلوم جميعها، لكن

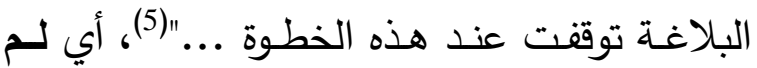
تمتد بمبادئها العامة إلى تفسير الظواهر، وتأويل دلالاتها، وبحث كيفيات بنائها وتثثكلها وتعالقها؛ نتيجـة الاعتقـاد بمنطقيـة هذه المبادئ وتعاليها ولا-تاربخيتها، وأنها غير قابلة للنقض أو التبدل أو التغير عبر تحققاتها الممكنة بفعل الحالات ولاستعمالات الفرديـة التي هي في واقع الأمر ما يمـنح النظـام/ القاعدة/ المعيـار/ اللسـان ظهوره، ويشـكله عبـر التـاريخ، ويجعلـه عرضــة للتحــول والتغير، فمن شأن الخطاب أن يوطل وجود اللسان نفسه، ويخرجه عن وجوده الافتراضي واللا-زمني. ليست الأزمـة إذن في طموح البلاغـة نحو ودو
العربيـة وعلومهـا عـن هـا التصـور ، فكمـا يقول التفتـازاني (792هـ) في شـرحه لتلخـيص مفتـاح العلوم: "... (وهو علم) أي: ملكة يُقتدر بها على إدراكات جزئيـة ... وَضْــعُ عدة أصـول مستتبطة من تراكيب البلغاء، تحصل من إدراكها وممارستها قـوة يُتـمكن مـن استحضــارها، والالتفــاف إليهـا، وتفصيلها، متى أريد، وهي العلم ..."(2)، وهو مـا يعني أن البلاغة، بما هي علم، بنـاء لنموذج أو منوال عام مجرد للخطاب/ القول وأدوات وصفه وإعادة إنتاجه، بما يلبي الرغبة في السيطرة على استعمال اللغة في عمومـهـ. إنها صياغة للقوالب أو تصنيف للوجوه والأشكال والصسور، يحيل إلى ما هو موجود، أو بالأحرى إلى ما هو منتقى من تراكيب البلغاء، بقدر ما يختزل بداخله كل ممارسة أو ظاهرة كلامية أو أدبية محتملة، ويحدد مصيرها قياساً إلى معايير هذا النسق التي تتمتع بسلطة أو قوة ملزمة، دونما حاجة إلى تبريز أو سند من العقـل أو مسن خارجـه، فهـي »أصـوله - وفق عبارات القنّوجي (ت 1307هـ) - مسلّم بها على سبيل حسن الظن دون أن تكون بيّنـة بنفسها، إذ يكفي أنها مسـتنبطة مـن تراكيـب البلغـاء، مدـا يضمن بقاء ها طويلاً آمنة ومستقرة. (3) هذا التطلع إلى صياغة مبادئ كلية وقوانين عامة، وما يرتبط بذلك من نزعة تصنيفية، لم يكن في الحقيقة شأن البلاغـة العربيـة وحـدها، ولا يهـم كثيـراً في هـذه الحال وصفها بأنها كانت أكثر إمعاناً من غيرها مسن البلاغـات في المعياريـة والصـورية، بـدعوى خلطها بين الأجناس الأدبية، وإغفال ما بينها من اختلافات وتمايزات، ف"... فكرة المعيار .. كانت 
أو principle of linguistic relativity فرضية وورف-سابير Whorf-Sapir التي تقول بأن اللغــة، والكـلام بالتـالي، يبــأ مـن تصـنيفات

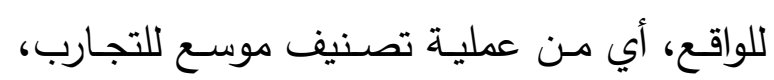

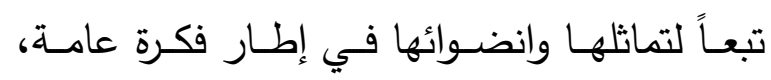

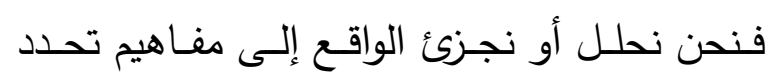

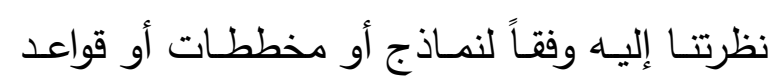
تصنيف في لغتتا (قواعد، مقولات، مكونات)، بما

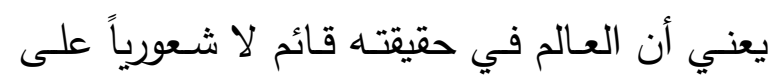
أساس معايير لغوية محددة. (8)

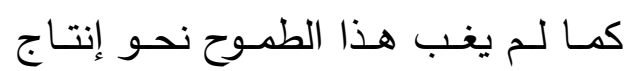
نماذج كلية عن مشاريع تطوير البلاغة وتجديدها

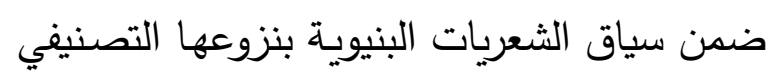

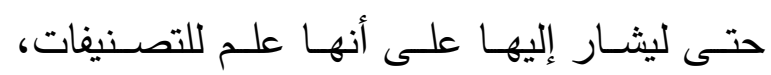

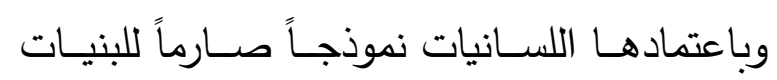

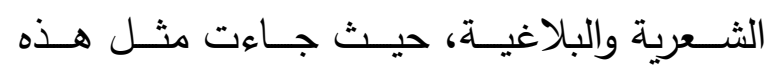

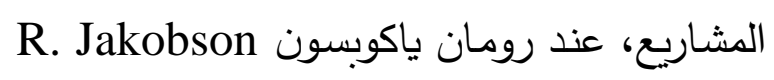

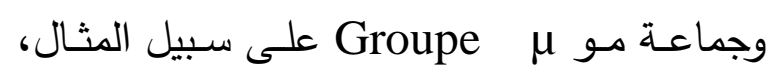

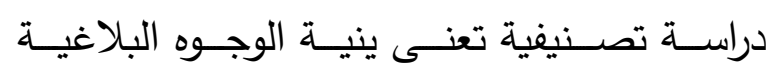

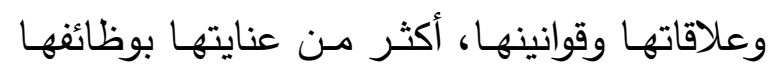

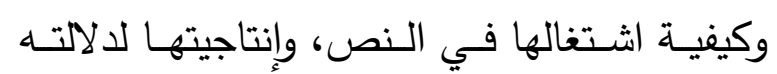

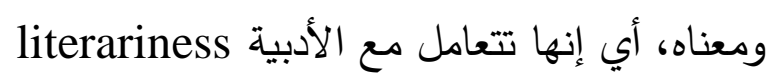

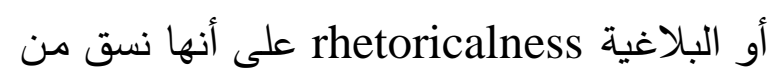
الإجراءات والأشكال العامة التي لا يمكن اعتبارها

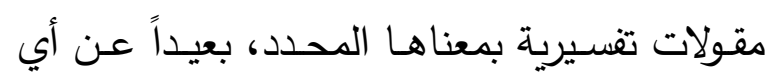

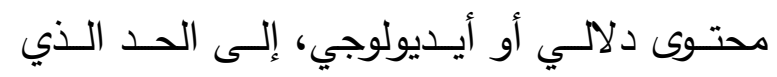

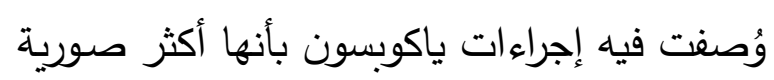

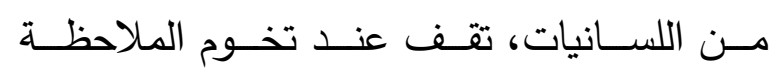
والتصنيف، وتأخذ الظواهر (التوازيات والتوازنات

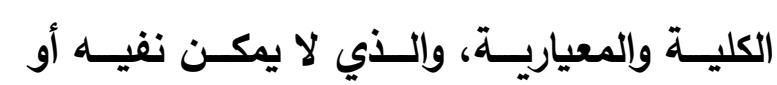

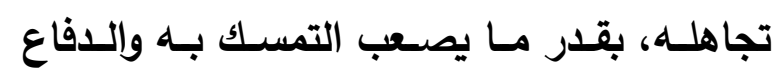
عنه، إذ يقترب هذا الطموح من أن يكون قدراً

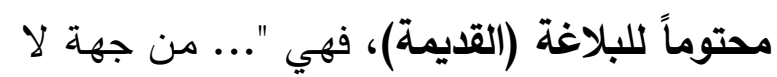

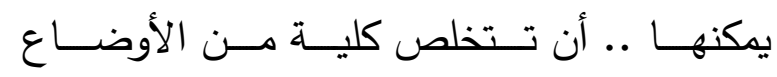

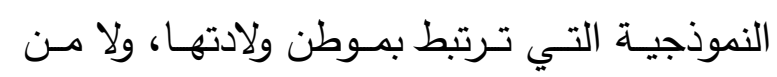

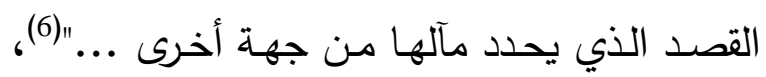

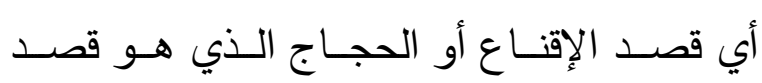

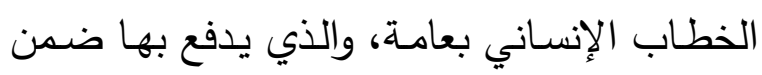
عالم الممكن أو المحتمل. هذه الحتمية التاريخية

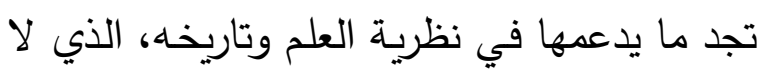
يكاد يتخلى عن وضــع تصـنيفات أو فرضسيات

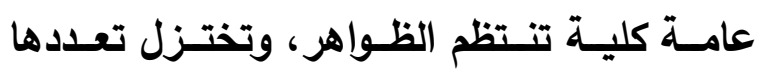
وتنوعها، وتثكل منها وحدة أو نسقاً منسجماً، وتئل مما يجعلها بمثابة معايير أو ثوابت يتم قبولها وتها

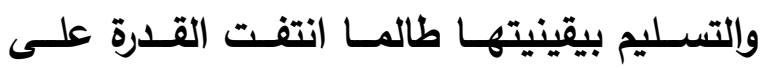

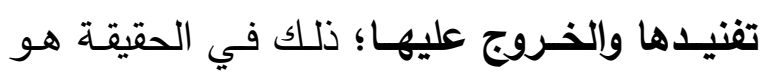

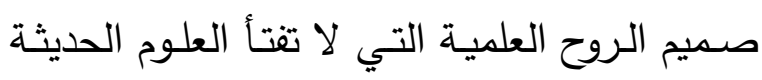

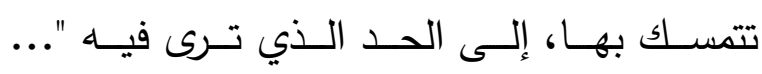
موضـوعية الحقيقـة والفكر تكمـن في معياريتهـا ..."(7) ومن ذلك على سبيل المثال ما عليه الحال

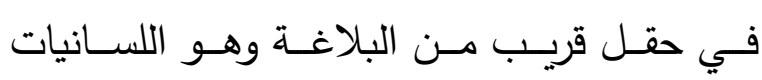
linguistics هيكلة للواقع، وتقطيع تصوري لمعطياته، وتنظيم

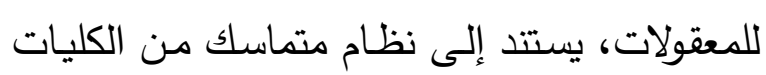
التصورية تحقق الإفادة (بمراعاة قواعد الإسناد)،

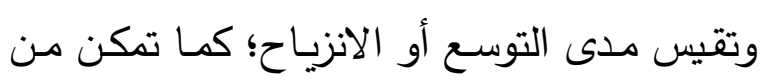

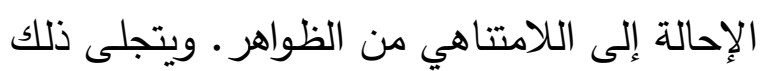

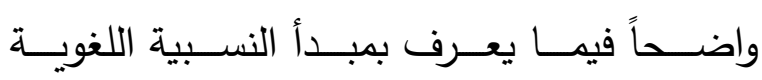


العلمية بما يتوافر لها من إمكانات تفسيرية، إذ ليست "... مهمـة المحلـل مجرد وصف مدونـة، وإنما تعليل البنية والمعنى اللذين تتضمنهما تلك المدونة بالنسبة لأولئك الذين أمكن لهم تمثل قواعد

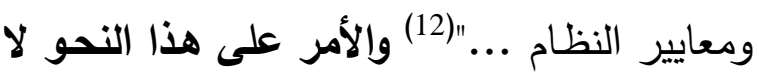
يعني رفضاً أو تخلياً أو تحولاً عن المعياريـة إلى والى

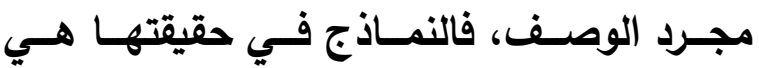
توصيفات، أو هي بديل ممكن لوصف الظواهر

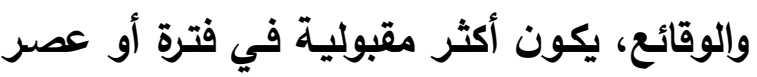

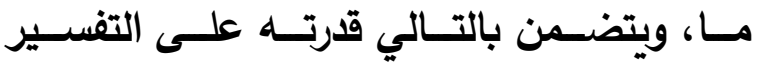
والتأويل؛ كما يبقى على الدوام في وضع إثـكالي بالي مـع الوقائع بتنوعها وتغيرهـا. وهو مـا يعني أن أن البلاغة تبقى بحاجة متجددة إلى أن تغدو تفسيراً

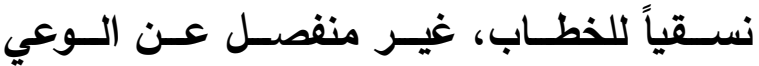
بخصوصـيات كل خطـاب وفق مبـادئ خاصـة: نوعيـة ونصـية، ممــا يستلزم بالضــرورة وجـود بلاغــات نوعيـة خاصـة. ولكن هـل تمثل هذه البلاغات بدائل عن البلاغة القديمة أو المعياريـة

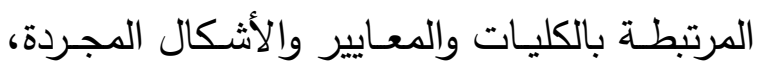

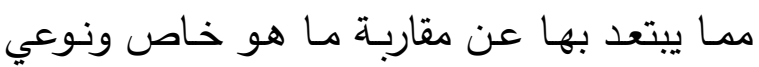
ووظيفي في الخطـاب؟ أم إنها انفتـاح بمجـال البلاغـة القديمـة والكلاسـيكية وتغيير جذري في الفي منهجيتهـا حتى تسـتوعب الخطابـات والأشـكال التعبيريـة على تعددها وتنوع أجناسها، ووظائفها،

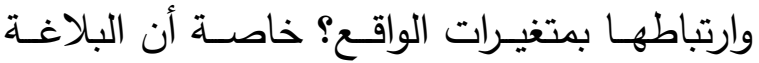

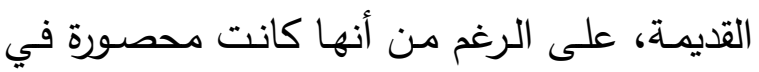
مقامات محددة، وأجناس تعبيرية محددة، فلم يكن

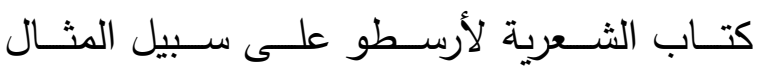

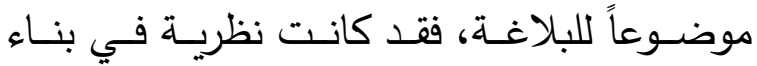

في القصيدة) بمعزل عن سياقها الخاص.(9) بل إن مـا سعت إليهه جماعـة مو من إعادة توظيف لفيف للموروث البلاغي ونماذجه في أفق نظري جديد،

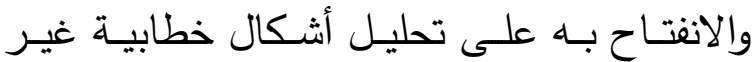
معهودة (السرد، التواصل المرئي)، تأسيساً لبلاغة خلئة عامة تتناول الظواهر في عمومياتها، ووفق قواعد ونمـاذج عامـة منطقية غير محصورة في مجال خاص؛ هذا السعي قد حدث دون تغيير المبادئ المحـددة لبلاغــة الخطــاب. فالجماعـة اعتمـــت

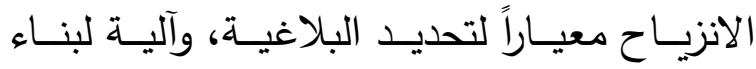

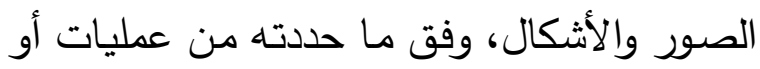

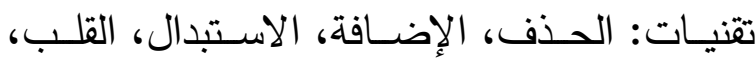
على مسـتويات متعـدة لغويـة ونصـية، بتجـاوز

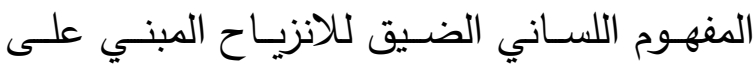
ثنائيـة اللغــة والكـلام، ولكن دون العنايـة بتفسير جمالياتهــا وتأثيراتهـا، ومـن غيـر التفــات إلـى لـى الخصوصية النوعية للخطاب. (10) تكثـف نظريــة العلـم وتاريخــه إذن عـن أهميـة وضـع نمـاذج ومعايير وتصنيفات ومبادئ عامـة شـاملة، غير أن تحـول هذه المبادئ إلىى نسق مغلق مُعد سلفاً، واختزال العلم إلى مدونـة

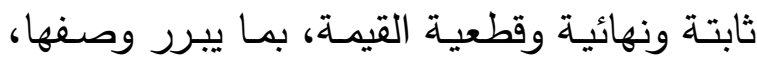

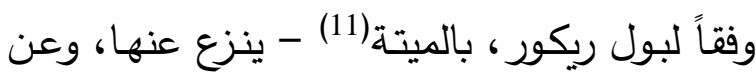
كل فكرة مسبقة، وكل صورة شاملة، وكل حقيقة

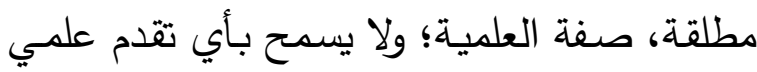
يمكن أن يتجاوز حدود الوصف والتصنيف، حيث

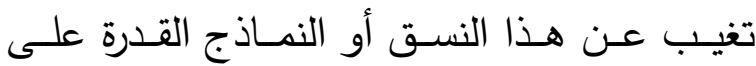

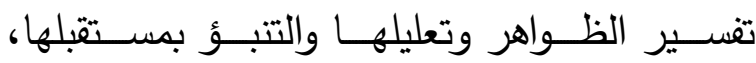
فالنظريـة أو النستق أو الفرضية تكتسب قيمتهـا 
النقدي) في المقابل بالارتداد دومـاً بالقول إلى

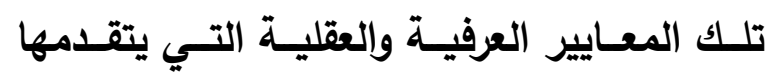
المعيار اللسـاني ممثلاً في المستوى اللغوي العام

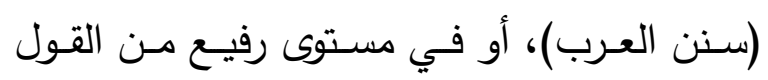

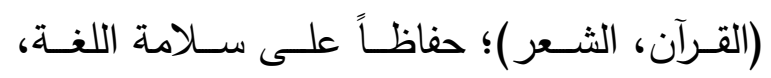

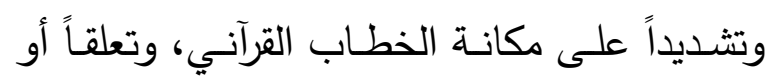

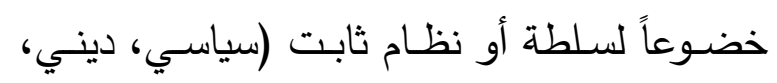

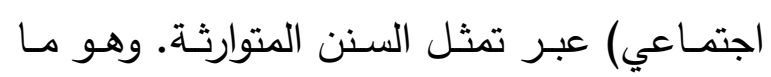

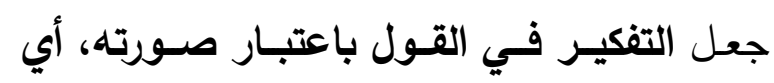

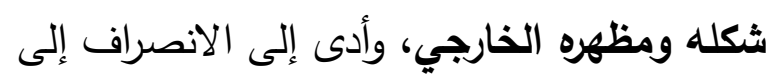

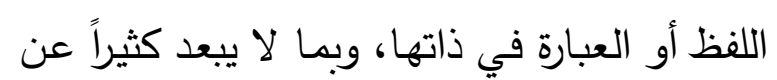

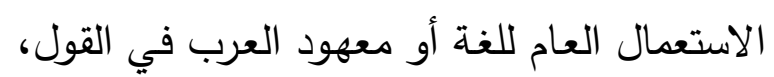

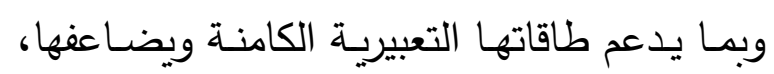

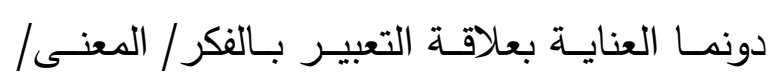
المدلول/ المضمون، أو بارتباطه بشخصية المتكلم

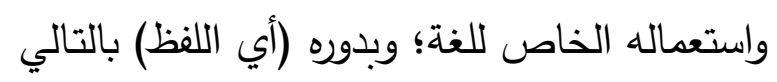

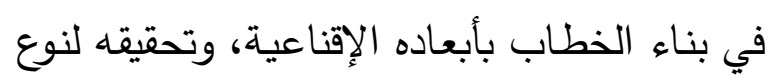

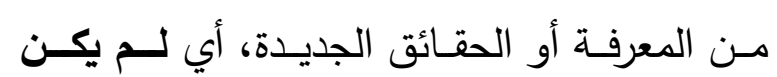

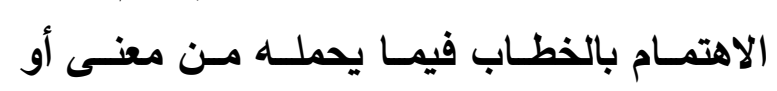

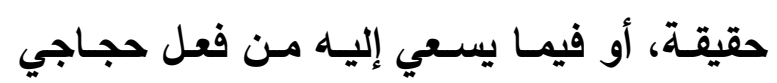

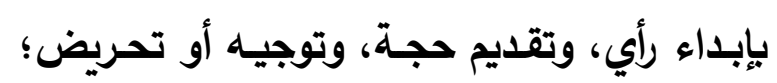

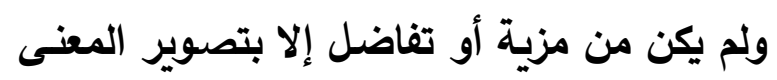
وكثفه وإخراجه في مظهر شكلي لـه قدرته على إنى التأثير والإمتاع؛ لتتحول البلاغة نتيجة لذلك فئل إلى فئل

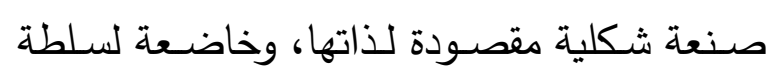

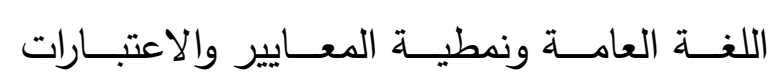
المقامية، يراد بها تكريس قيم فكريـة وأيديولوجيـة

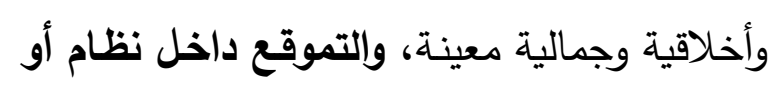
وجود قائم ومتوارث لا يقبل إلا بالتشابه وإلتكرار
الخطاب، تتسع لاحتواء أنماط أخرى من الخطاب

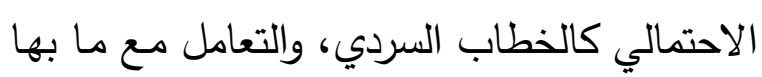
من عناصر حجاجية وأسلوبية وتداولية، على نحو ما جاء في إطار ما يسمى بالبلاغة العامة بتعدد

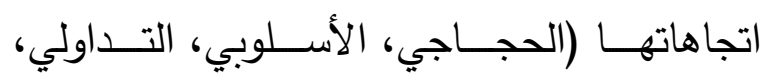

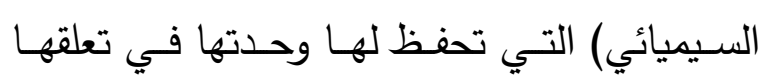
بالبعد الإقناعي والتأثيري، وتبقي على طموحها في

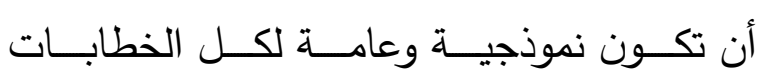
والنصـوص، وتمنحهـا كفــاءة إجرائيـة في تحليـل خصوصـية كـل خطـاب (احتمـالي) وإمكانياتـهـ التعبيرية. كانت البلاغة العربية في نزعتها الصورية،

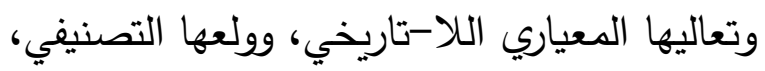

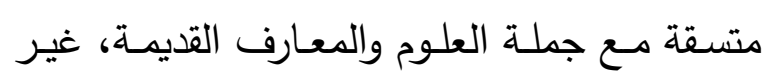

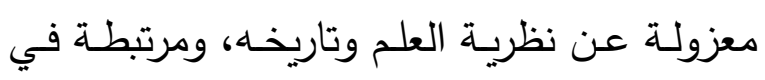
الوقت نفسـه، بـل محكومـة، بسؤالها النقدي إزاء الخطاب/ القول، الذي يخضع لاعتبارات ومعايير

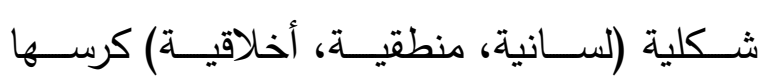

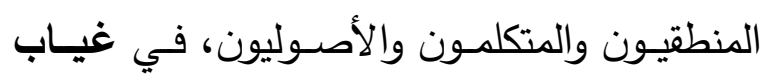

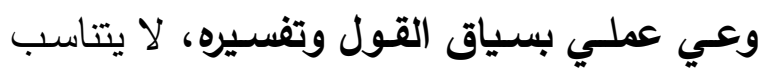

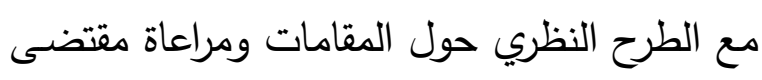

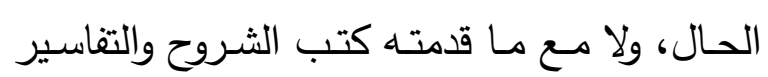

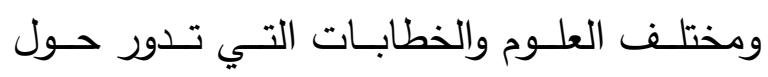

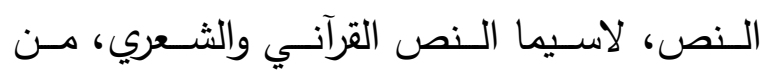

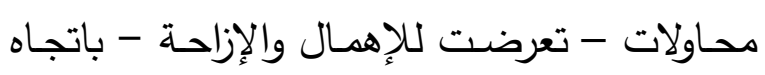

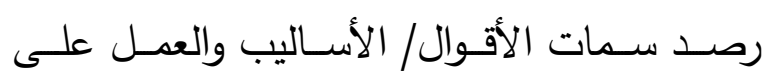

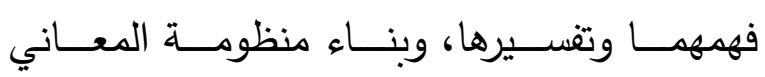

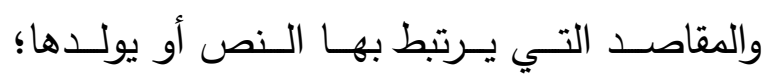

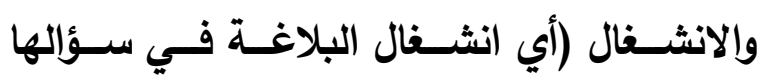


العربيـة في المجمـل كانـت استجابة للحاجـة "... إلـى نظـام لغـوي يحقـق مطالب التـرف، وتوجيـه الناس، وسيادة السلطة ... ويحقق تبعاً لذلك متعة

غير عادية باللغة ..."(13)

على هذه الثنائية: الثكل والمعنى، أي مـا

بـين التركيـز علـى مضــمون الخطـاب وغاياتـهـ الإفهاميـة التبليغيـة، ومـا يـرتبط بـذلك مـن عنايـة بالثكل اللغوي بما هو حليـة وزينـة وكسـاء يغلف هذا المضمون، ويخرجه في أحسن صورة وأبهاها؛ ليحقق غايته من المخاطب من إقناع وتأثير ؛ وبين إقصـاء المعنـى خلف شبكة هائلــة مـن الأشـكال والصور والمجازات؛ على هذه الثنائية أو المفارقة ستحيا البلاغـة العربيـة على امتداد تاريخهـا "... باعتبارها احتفاء بالثكل وتغييباً له في نفس الآن،

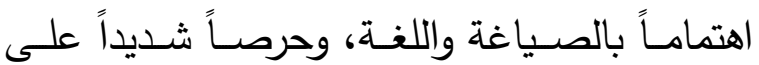
وضوح المعنى، والعمل على اختراع الآليات القادرة على إدراك ذلك الوضوح، إن وقف دونه إشكال أو التباس، مثل آليـة التأويـل التي لـم تكن إلا نهجـاً موصـلاً إلى معنى أول قام في النص مـا يحجبـه عنـا إلى حين نجد الطريـق إليه. والحرص على وضـوح المعنـى يقتضـي مـن اللغـة أن تكون في غاية الثفافية، تؤدي إلى المعنى بدون أن نشعر

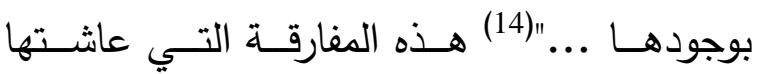
البلاغة تدفع بالدال/ الكلام/ الخطاب في علاقته بالمـدلول/المعنـى/ المرجـع نحــو التعسـفية أو الو التحكمية التي هي بالأسـاس سمة الدليل المفرد، في حين تنتفي في عمليـة إنشـاء الخطـاب "... سـمة التواطـؤ بمـا تتضــــه مـن تحكم واعتبـاط لتتحول إلى نظام معبر عن الأشياء ..."(15) فلم
والنسـخخ (عبر النقل والتلقين والتعليم المدرسي)، ويعلي من قيمـة الوضـوح والبيان الضـامنة للفهم،

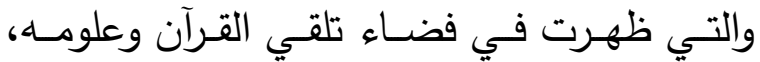
وينفر من الغموض والتأويل، ومن الاختلاف في الآراء والمواقف، بسبب التشبث بسلطة الإجمـاع والنقل، وسلطة المعنى الحرفي أو الظاهر للقرآن وفق التصور الحنبلي؛ وبسبب تراجع الحاجة إلى الحجـــاج والجــدل والخطابــة، لتراجــع الحريــات والاهتمام بالثأن العام؛ وارتباط الاحتجاج بما هو

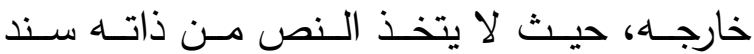
حجاجـه، بـل يبنيــه مـن خارجـه، ومـن هامشــهـ (السياسـي، التفسـيري ...) الــذي يحـل محلــه. تحولت البلاغـة إلى اهتمـام بصـورة القول وشكله وصسياغته، ومـا يـرتبط بذلك مـن إحكام الصـنعة، والتحسـين الثـكلي، والتناسـب العقلي والمنطقي، فغدت 》لعباً باللغةه يحقق الإمتاع والتأثير، بقدر مـا يمسارس التمويسه والمخايلـة بالثـكل؛ لإقصـاء المعنى، وإلهاء النـاس عن حقيقـة الواقـع وعن ممارسات السلطة، ومن ثم عن التطلع إلى بديل مختلف ومغاير • حدث هذا التحول للبلاغة باتجاه الثكل أو الأسلوب بعد أن كانت لها من قبلُ على امتداد تاريخها منزلتها المستمدة من وظيفتها في المجـال الفكـري والعقائدي والاجتمــاعي، والتـي

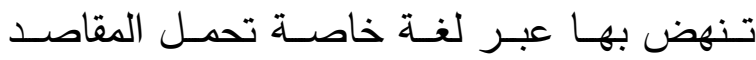
والمعاني والتصورات والاعتقادات، وتتشكل بحسب المقامـات والأحـوال، وتلبـي توقعـات المخـاطبين، على نحو يكثف - من بعض الوجوه - اعترافاً بسلطة اللغة وسيادتها، حققه المعطى البلاغي في الفكر العربـي، ممــا يسـمح بـالقول بـان البلاغـة 
المحدودة؛ ودونما اعتبار - عملياً على الأقل -

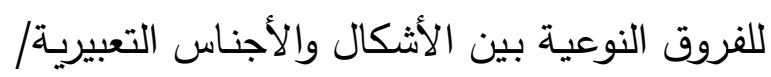

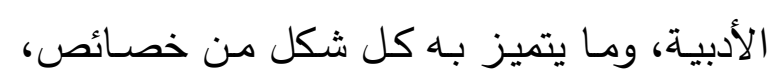

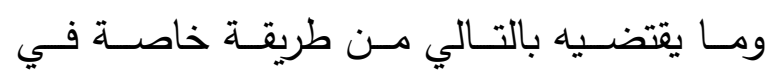
الاستجابة والتلقي. فهي تضع الشعر والنثر ضمن بلت فاصن

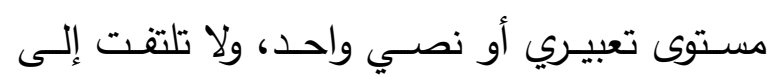
تفاوت الأساليب بحسب الجنس الكتابي، فتُجْري سمات نوع ما، كالوضوح في النثر / الخطابة مثلاً، على نوع أدبي آخر ، فتطالب بـه في الثعر ، بل فل فئل يغـدو مـداراً لثـروط فصــاحة القـول كلـه: مفـرداً ومركباً (في اشتراط خلوه من الغرابة، ومن التعقيد

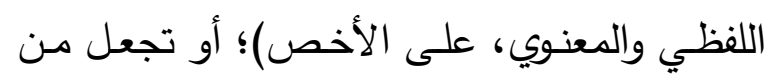
البعد التداولي والإقناعي الحجـاجي الأدخل إلى الـى الخطابية - مقياساً لتأثير الثعر وفيمته الجمالية؛

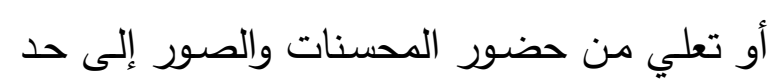

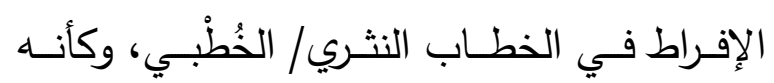
بمثابة بديل تعويضي عن غيبة العناصر الثعرية

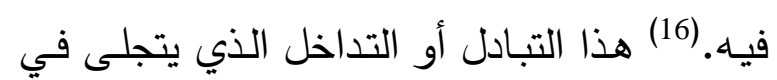

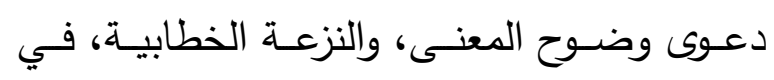

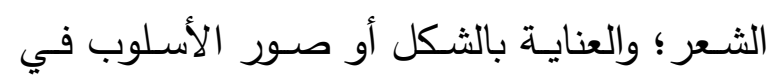

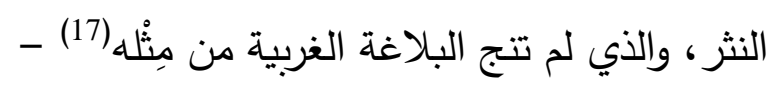

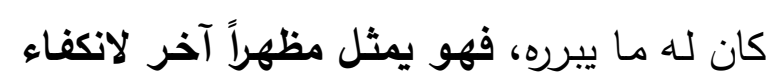

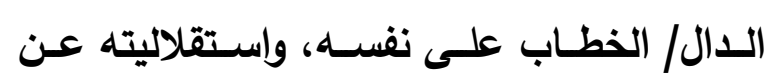

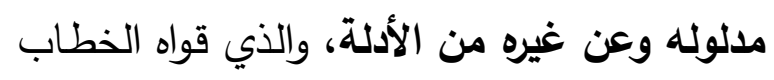

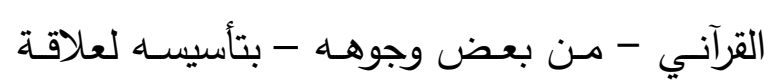
جديدة باللغة، أو لوجود/ عالم جديد باللغة. إنـه منطق الثعر، والخطاب القرآني كذلك، في تصور البلاغيين العرب، حيث استخدام اللغـة يتجـاوز

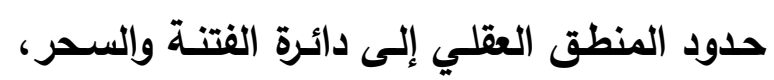

يكـن الخطـاب، في التصـور البلاغس، يعترف

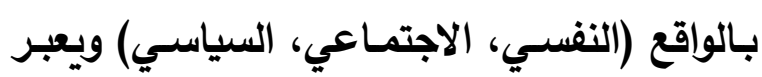

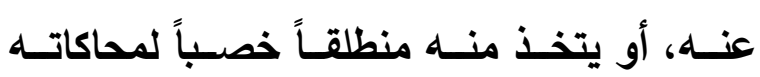
وإعـادة بنائهه، واسـتيعاب تحولاتـه، وكأنمـا هـا

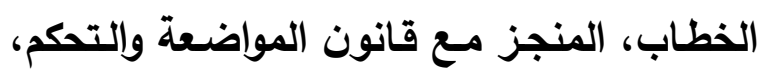

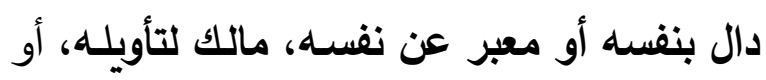

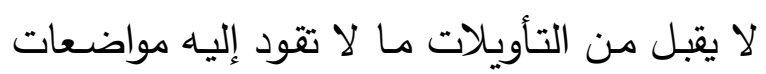

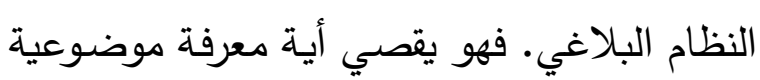

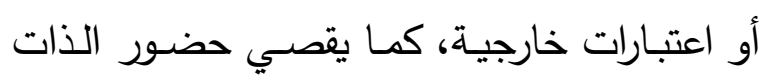

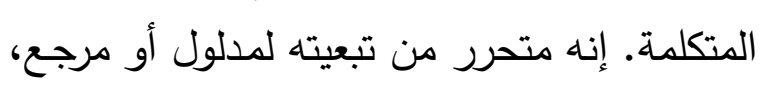

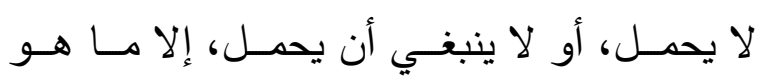

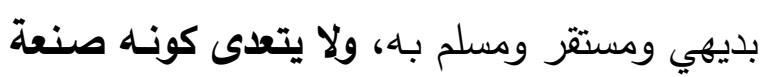
تحتذي نموذجاً قبلياً هو نستخ أو صورة منسه في ولهاي نوع من الإحالة الذاتية. كان لتك المفارقة أو التوزع ما بين الثكل الثاله

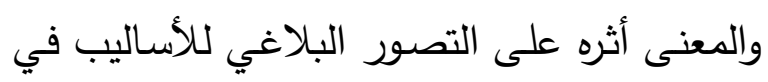

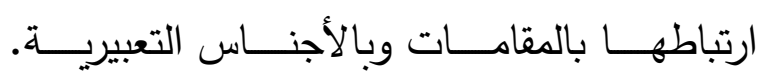
فالأسـاليب هي في حقيقتها تصـرفات في اللغـة، تتحرر من وطأة الضرورة اللغوية، ومجاراة السائد

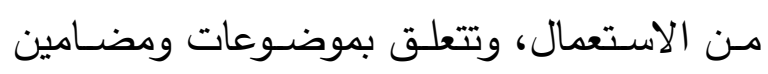

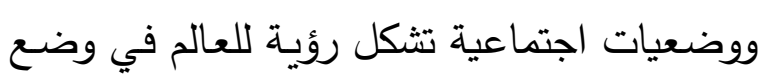
تاريخي محدد، ووفق مقتضيات تداولية واعتبارات جماليـة، وتحمـل بـذلك طابعـاً نسـقياً تصــنيفياً: وظيفياً أو تركيبياً. هذه الطبيعة النسقية للأساليب اتخذت منها البلاغة العربية معايير حاكمة للقول وللجنس الكتابي، مع كثير من التعسف والتجريد،

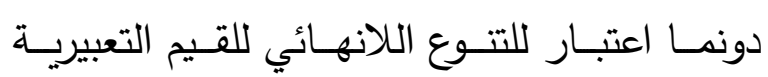

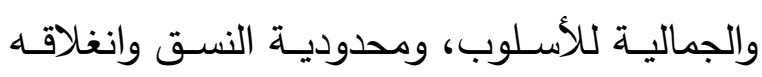
أمسام مقاصـــ الفـرد وانثـغالاته المتجـدةدة وغيـر 
واللسانية، وإن كان التصور القديم الذي يرى في الإقنـاع والتخييـل سـتين فـارقتين بـين الخطـابي والثــعري، التـــاولي والجمـالي، دون أن يعـدما

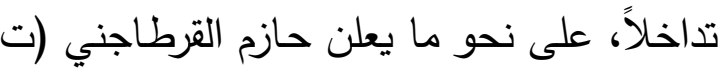
684هـ) في قوله: "... كان علم البلاغة مشتملاً

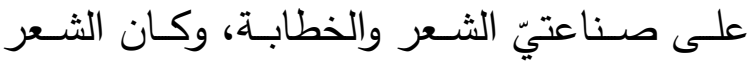
والخطابـة يشـتركان في مـادة المعـاني، ويفترقـان

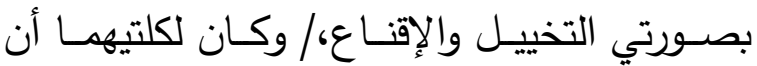

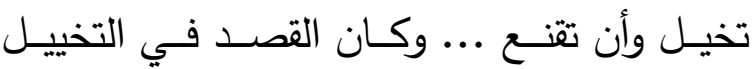
والإقناع حمل النفوس على فعل شيء أو اعتقاده،

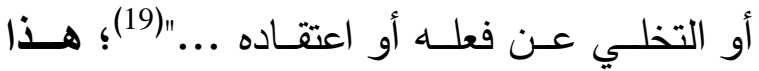
التصــور القــيم مـن شـأنه أن يجعـل النسـق النق

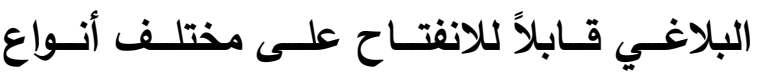

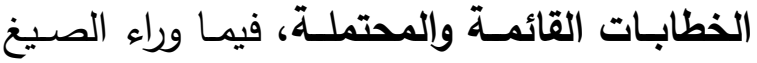
النمطية والنموذجيـة المتوارثة، فيكون قادراً على اسـتيعاب التـــولات فـي الخطابـات والأجنـاس التعبيرية، وتجاوز الانفصام بين بنياتها ووظائفها وبين الأشكال والتصـورات البلاغيـة القديمـة. (20) وهو ما لا يعني بالضرورة التخلي عن هذه الأخيرة

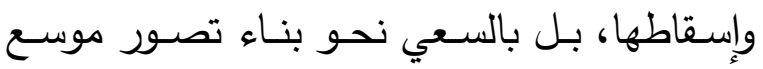

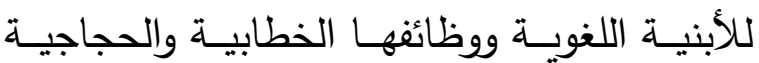

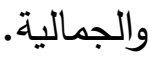

في حداثة الـنص البلاغي القدليم : مسـاهمة ابـز البناء

يرتبط وجودنا، حاضرنا ومستقبلنا، بالتراث/ الماضـي، بقدر مـا تفصلنا عنـه أزمنـة ومضـامين وأنسـاق قيميـة مغايرة تحول دون استعادته لنحيـا

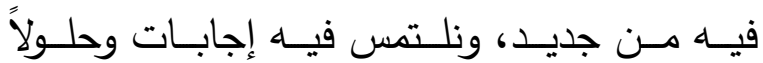
لقضـايانا ومشـاكلنا وتساؤلاتنا الراهنـة. هذا التراث
وينفك فيه ارتباطها بالمعنى، وقد يتوارى المعنى تمامـاً لحسـاب الثـكل، في" ... الثعر ل.. يستمد كونـــه مـن شـكله، وفضــله مـن بنيتـه ... [و ] الإعجـاز في الخطـاب منـاط أسـاليب القول، لا لا

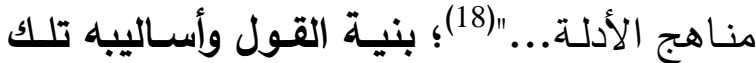
التي يُنظر إليها ضمن ما هو متاح وقابل للفهم في حدود أفق القوم المعرفي والجمـالي. أما ما كان مخالفاً لتوقعاتهم، كذلك الذي وجدوه لدى أرسطو، فيتت عند الترجمة أو الثرح أو التلخيص طمسـه، بإسـقاطه وتغييبـه، أو بإخضـاعه لقـراءة

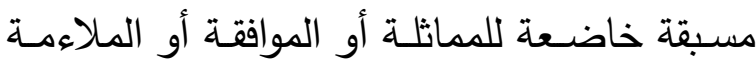

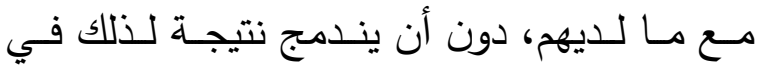
صميم تصورهم للشعر وتعاملهم معه.

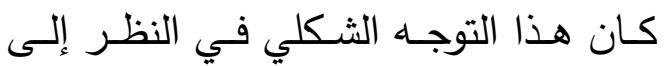
أساليب الخطاب هو السائد لدى البلاغيين العرب،

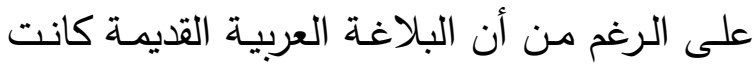

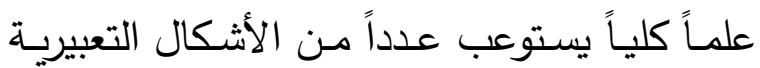

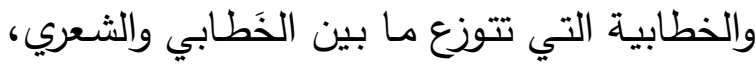

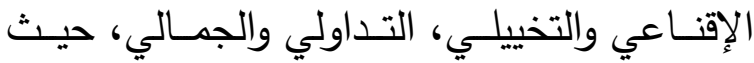
انصب اهتمامها على أنواع محددة من الخطاب كان لها مكانتها فـى الثقافـة العربيـة الإسـلامية، وهي: القرآن، الثعر ، الخطابة، فصـارت البلاغـة

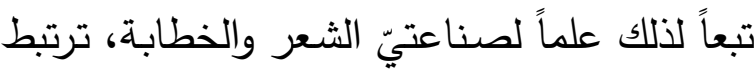

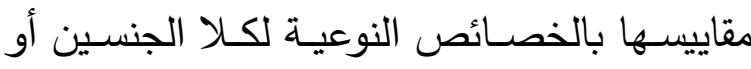
الصناعتين دون غيرهما من أجناس تعبيرية. وهي لهيل

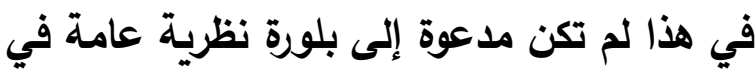
الأجنـاس، وكان عليها أن تنتظر تطور أشكال الكتابـة، وظهـور أجنـاس تعبيريــة جديـدة عبـر التـاريخ، وتطــور المقاربــات والمنــاهج النقديــة 
كانـت للسـكاكي (ت 626م)، ومـا زالـت،

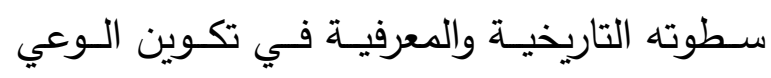
البلاغسي العربـي، فقـــ اكتسـب نموذجــه - عبـر مختصـرات وتلاخيص وشروح وقراء ات لدفتاحسه

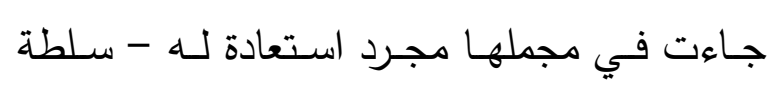
تعيـين البلاغـة أو الحقيقـة البلاغيـة، بـل سـلطة

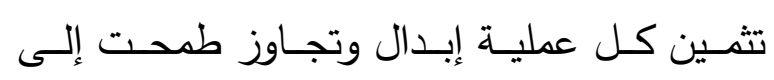
الانتقال من نسقه البلاغي المنطقي-اللساني الذي ولي

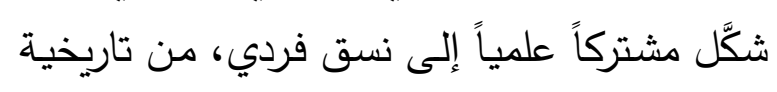

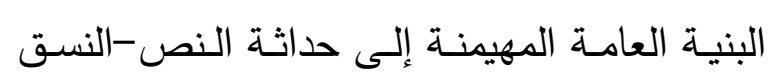
الذي لم يَرُق لـه الانخراط ضمن العام والمهيمن

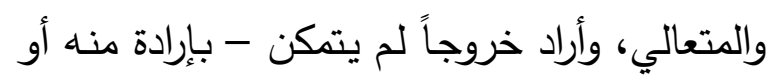

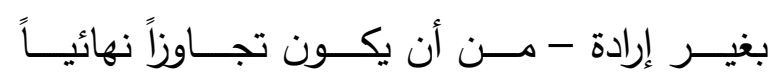
للمتعاليـات، أو نفيـاً منقطع الصـلة معهـا، فـ"...

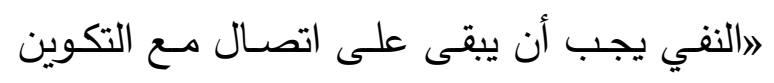

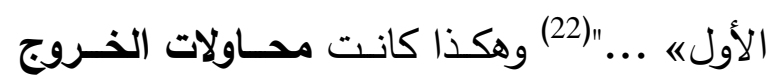

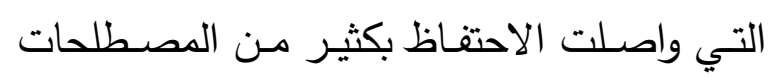

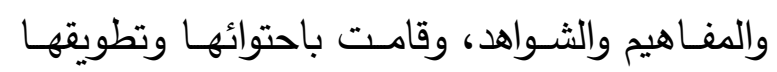

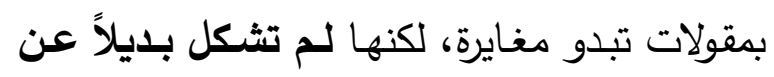

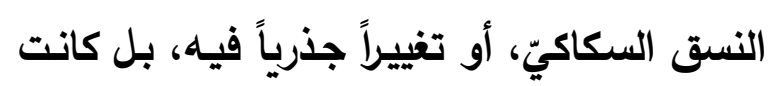

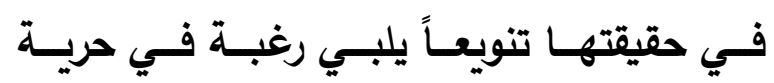
الاختلاف أكثر منه نقضاً او سلباً حتى لو أعلنت

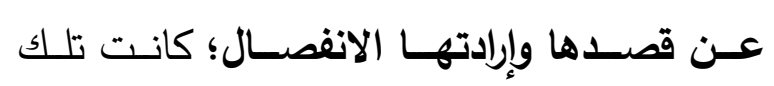

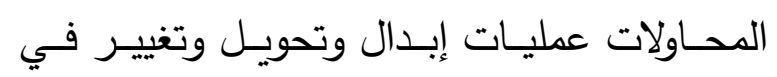
بعـض العلاقـات وبعـض الأسـس والمبـادئ

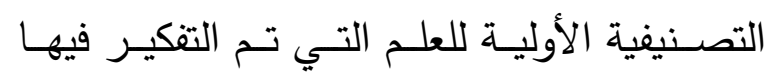

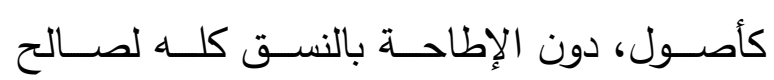

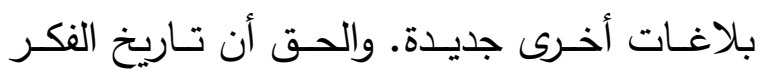

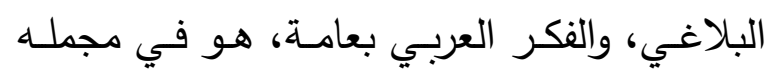

قد يكون قابلاً للتجديد أو العَصْرَنَة وإعادة القراءة

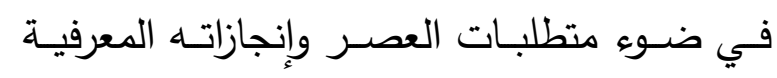
الهائلة، فيُستدعى منـه مـا هو قابـل للحياة فينا،

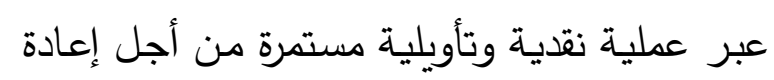

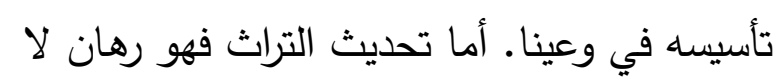

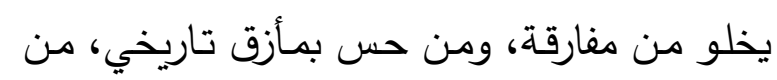

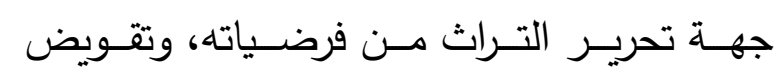
مسلماته، ونزع ما يعلق بـه من تعالٍ ولاعقلانية.

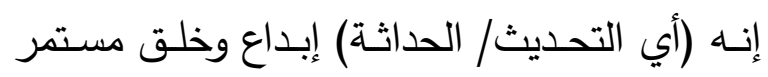

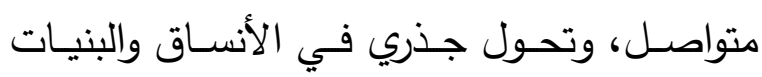
المؤسسة له، وخروج وتمرد على الطرائق المتوارثة

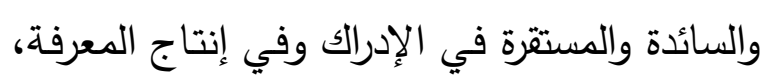

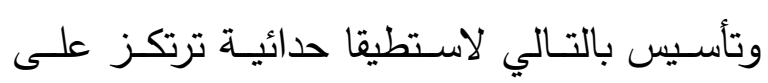

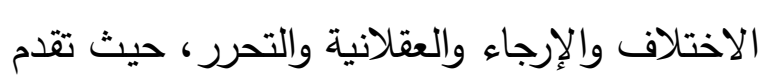

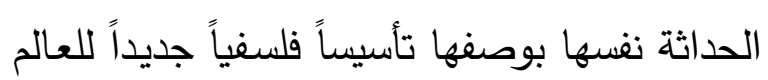

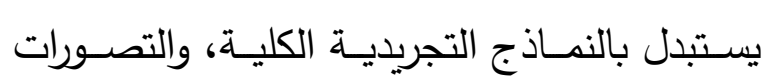

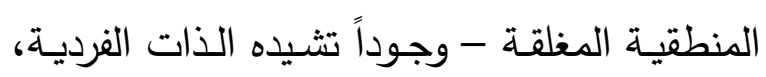
تأخذ موقعهـا فيـه، وتقيم رابطتهـا الاجتماعيـة،

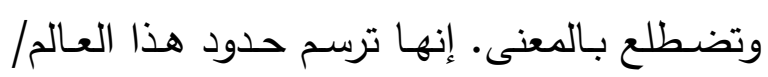
الوجود، "... تلك الحدود التي عبر عنها جوكفرد عندما قال: 》اليس هناك واقع خارجي، إذ لا وجود

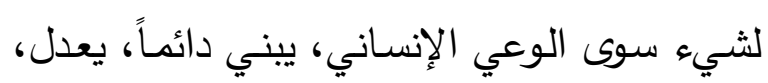
يعيد بناء عوالم جديدة من خلقنا الخاص.ی" "(21) وضمن هذا الوجود يتم تجاوز منطق المطابقة،

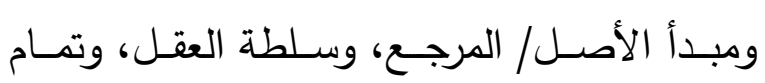

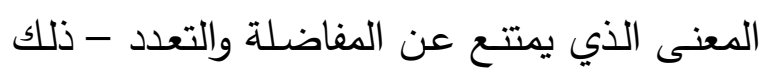
الذي أرسته البلاغة القديمة، وكرست لله بطابعها

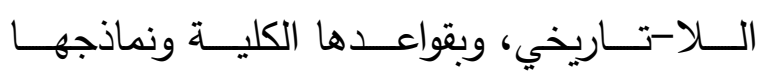
التصنيفية. 
بـذلك مـن تلقـى مـراد الله تعـالى مـن كلامــه على وجهـهـ وتمامــ؛ الأمـر الـذي يعلن عـن تأســيس علمـي للبلاغـة، وتحولهـا إلى علـم كلـي ينشــ، بفروعه وعلومـه الجزئية وما هي عليه من تراتب وتداخل، وصـولاً وبلوغاً أو سـعياً نحو الاكتمـال، نحسو التمــام - بعبـارة السـكاكي: فعلمـا المعـاني والبيــان: (خــواص تراكيــب الكــلام، صــياغات المعنى) هما تمام علم النحو، وتمـام علم المعاني بعلميّ الحد والاستدلال: (خواص تراكيب الكـلام فى الاستدلال)، والواقف على تمسام مراد الحكيم تعـالى مفتقــر إلـى علمـيّ المعـاني والبيـان كـل الافتقار •(24)

هـذه المعرفـة البلاغيـة الكليـة تـأتي ضـــن التصور العربي للمعرفة، القائم على تداخل العلوم والمعـارف، لاسيما بصورته الأوضـح المتمثلة في التراتب المنطقي والضـروري، في"... العلوم مرتبـة ترتيــاً ضــرورياً، وبعضــها طريـق إلـى بعـض. والموفق مراعي ذلك الترتيب والتدريج ..."(25) هذا التراتب الذي يدعم في النهاية اتجاهاً نحو الوحدة

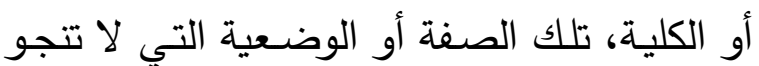
منها حتى العلوم الثرعية غير العقلية، كمـا هو الحـال مـع "علـم تعبيـر الرؤيـاهـ الـذي يـراه ابـن خلدون (ت 808هـ) - على الرغم من تأكيده بأن الرؤيـا تتعلق بمدرَكَ من مدارك الغيب أو الروح، أو بصـور النفس - "... علمـاً بقوانين كليـة يبني عليها المعبّر عبارة ما يُقص عليه ..."(26) وربما يرشـح لهذه الكليـة مـا كـان للتراتـب مـن انعكساس على تـداخل مصـطلحات العلـم مـع مصـطلحات غيره مـن العلوم، وربمـا امتد التداخل إلى بعض
تاريخ تحولات وأطوار ومراحل، بما في ذلك بلاغة السكاكي وشراحه ومن قبلُ عبد القاهر الجرجاني (ت 471م) وغيرهم. إنه (أي تاريخ البلاغة) بنية لا تشهد انقطاعاً أو تفكيكاً أو نقضـاً، بل تتحول عبر انتقـال يـأتي مشـروطاً بالتكوين الأول، أي بالسـابق والمعلوم والقبلي، ضـمن نسـق محكوم بفكرة الأصل ومحاكاته ودوام العود (الزمني) إليه أو دائربته، حيث "... الاصول تامة في السابق، وللاحق حق الاجتهاد الذي ليس لله خروج على القواعد الأساسية .. كما رسخها التصور الإسلامي للتـاريخ والـزمن، حيـث يكـون التقـدم عـودة إلـى البداية والأصل."(23) فلا وجود حقيقي للظاهرة أو الشـيء إلا في كونـه عودة، تكراراً، نسخاً بمعنى مـا، أو بعبـارة أكثر دقـة: لا حضـور للشـيء إلا

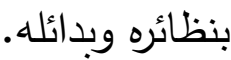

يتعامل السكاكي مـع البلاغة بوصفها علماً

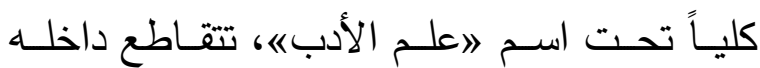
مجموعة من العلوم: لسانية (التصريف والاثتقاق والنحـو، المعـاني) ومنطقيـة (الحـد والاسـتـلال، البيان) وشعرية (محاسن الكلام/ البديع، عروض الثـعر ) تــتظم مــع بعضـها بعضــاً في منظومـة

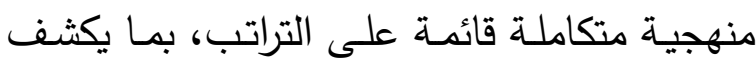
اختصـاص كـل علـم مـن علـوم البلاغـة ومجالـه وحـدوده، عبـر تداخلاتـه وتعاضـداته المعقدة مـع غيـره مـن العلـوم المتماسـة معـه في النظـر إلـى الموضوع ذاته، أي التعبير اللغوي، لتتحقق الغاية المتمثلــة في إنتـاج الكـلام أو الخطـاب (العربـي) على وجـهـ الصـواب وعدم الخطـأ، وتلقيـه وفهــــ وتفسيره حسـب المقاصـــ والمقامـات، ومـا يـرتبط 
الاعتبار ، وتوجد طرقهم في جميع ذلك تترامى إلى

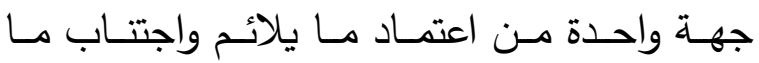
ينافر ."(29) هذا التتاسب والتلاؤم والتوافق المنطقي بــين المســموعات والمفهومــات، بــين الــدوال

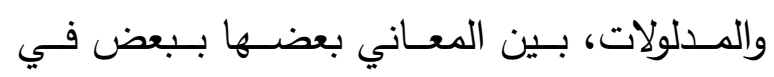

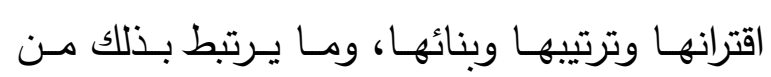

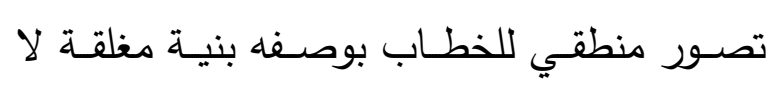

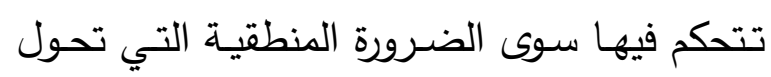
دون أيـة محاولـة للتجاوز وخرق للنظام، ولقانون

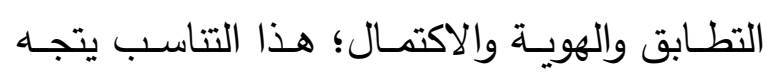

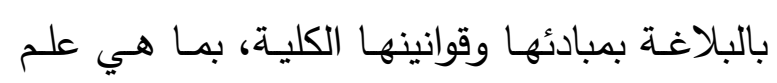
كلي عند حازم القرطاجني (ت 684هـ) كما عند السكاكي، نحو التوافق مـع نظسام العالم واستعادة منطقيته وتناسبه وانسجامه. إنها تعكس انتظامـه

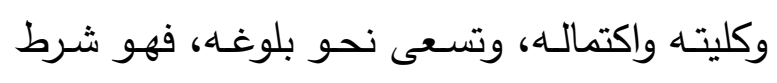

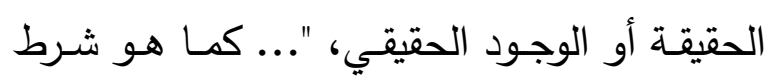

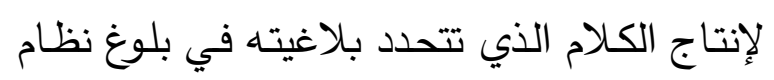
العالم، وتحقيق التوافق والتلاؤم الثـامل."(30 أي لئل إن البلاغـة لم تكن سوى مجموعـة مـن المعايير

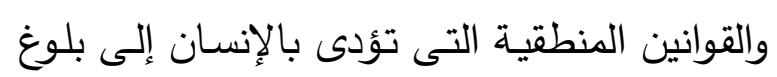

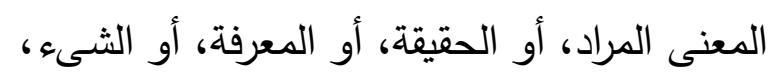

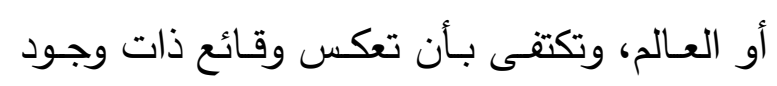
موضوعي، وثابت، ومستقل عن الذات (العارفة)؛

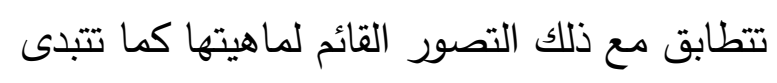

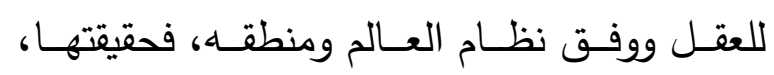

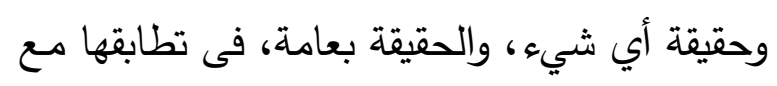

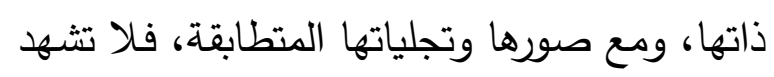

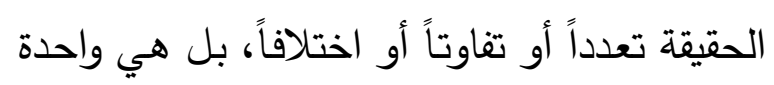

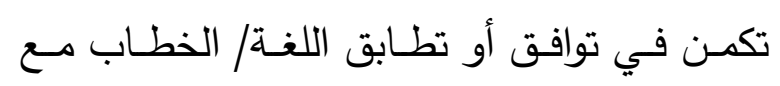

الإشكاليات المعرفية، ومن ذلك على سبيل المثال تغلغل مصطلحات الجدل والمنطق في كثير من الإنكال العلوم الإسلامية كعلم الكلام والنحو وأصول الفقه وله

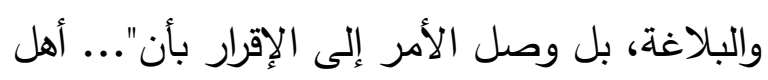

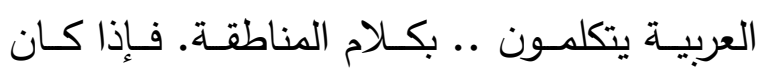
الطالب عاطلاً عن علم المنطق بالمرة، لم يفهم

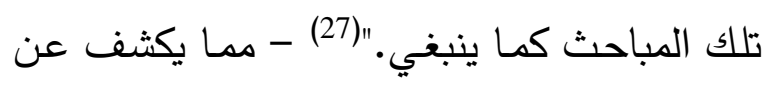

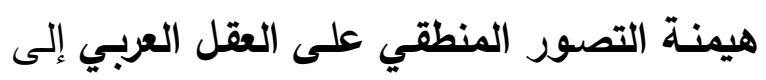

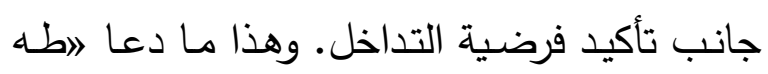
عبد الرحمنه، في بحثه عن منهجية لقراءة التراث الإسـلامي، إلى طرح فرضية أو الهعوى فئه التداخل

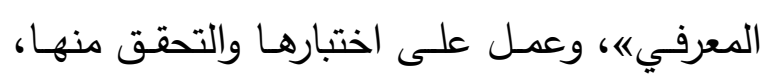

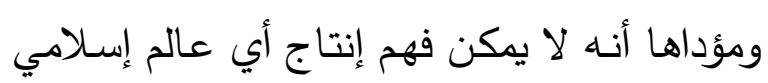

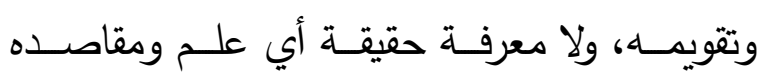

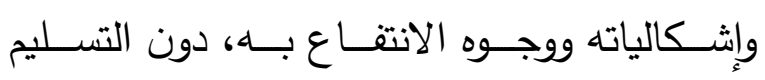

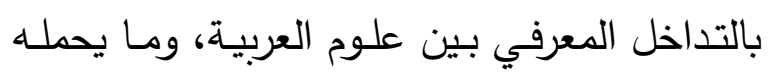
من تآزر وترابط وتفاعل بينها. (28)

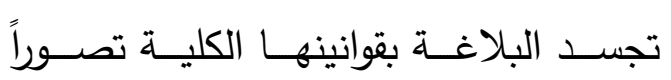

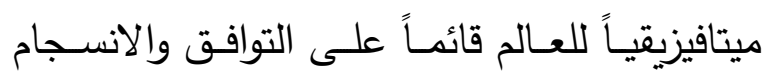

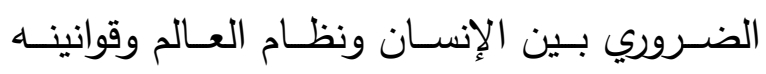

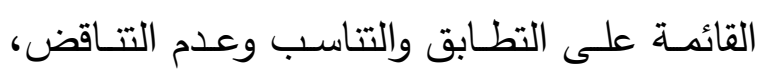
بــين التصـــورات والموجـودات، بــين الحقــائق

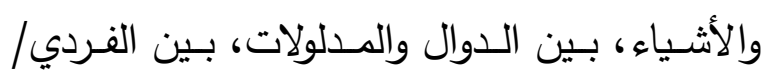

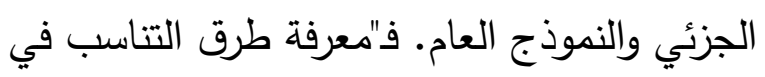

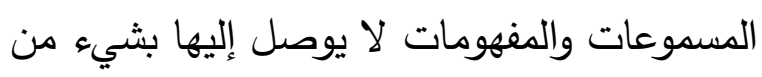

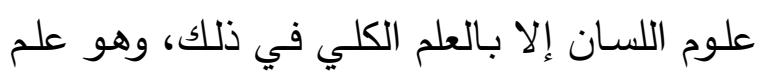

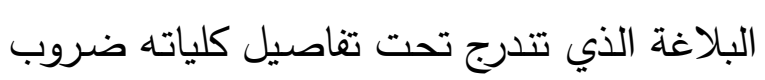

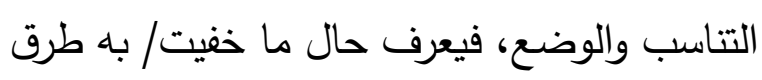

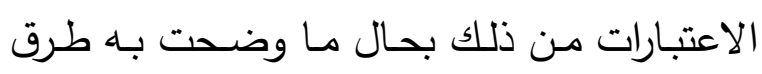


أو نموذج يقدم قوانين كلية تحكم عمليات الفهم أو

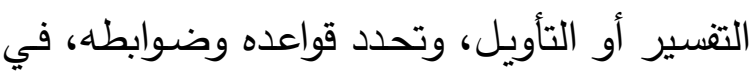

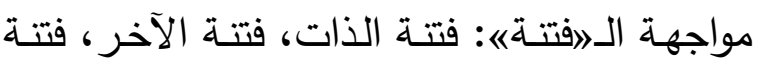

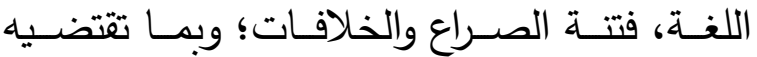
مطالب الأمـة من وجهـة نظر أيديولوجيـة تتبناهـا السلطة. إنـه "... ضبط قوانين البلاغـة، وقوانين التأويل، وعقل الخيال؛ لخدمة أهداف أيديولوجيـة

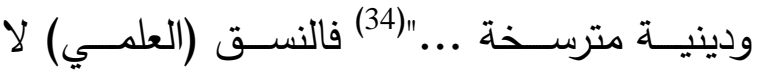

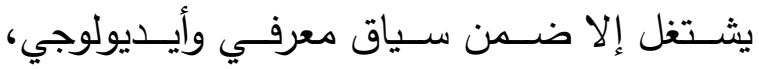
والنظريـات العلميـة كمـا بيّن فلاسفة العلم ليست وليدة موقف ذهني أو سيكولوجي، بل هي تنطوي على أفكار قبلية، مبـادئ خفيـة، مسلمات غير مبررة، حدوس غير عقلانية. (35) ومن ثم لم تكن من قوانين البلاغـة، كمـا هو حـال العلم في عمومـهـ وليس فقط التأويل، بمعزل عن أيديولوجيا السلطة أو النخبة التي تصطنعها، أو القيم والمثل العليا للجماعة؛ بما أن هذه القوانين (العلمية) تمثل وعياً

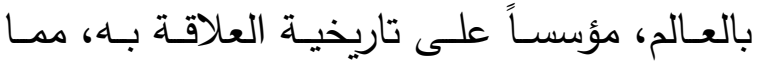
يعني أن العلم يشكل، في بعض نواحياه، نوعاً من الأن

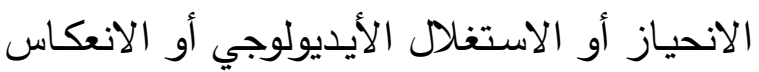

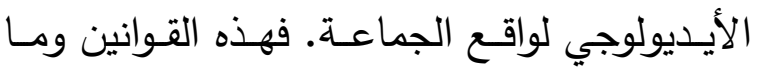

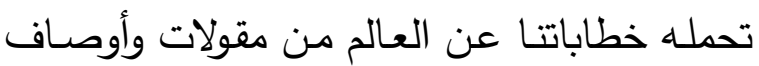
ليست بمعزل عن القصدية والإيديولوجيا، وعن فن لن الثروط التاريخية والاجتماعية والسيكولوجية زمن إنتاجها، إذ لا تثير بالضرورة "... إلى خصائص العالم كما هو، بل إلى خصائص العالم كما تقدمه لإسير

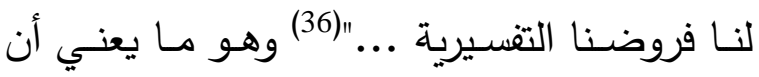
السعي نحو بلوغ حقائق مطلقة، قوانين ونمـاذج وصور وتركيبات وعلاقات شاملة للوقائع الفردية، لينات
الموجودات، المفهولات، التصورات. البلاغة بذلك

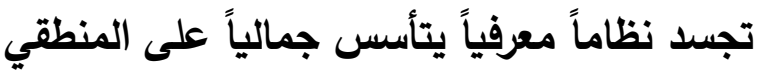
أو العقلي الذي يمثل النظام الكلي للعالم، والذي دئي تسعى، شأنها شأن العلوم العقلية، وكأنما أريـا بهذا التماثل إخراجها عن فضاء المحتمل؛ تسعى إلى مطابقة ذلك النظام في الخارج - وفق عبارة ابن خلدون. (31) فتكتسب بذألك بقاء هـا ودوامها، وتكون لها سلطتها اللا-زمنية في فرض هيمنتها

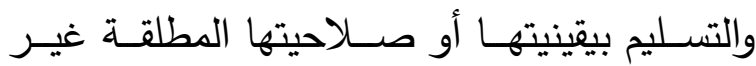
المشروطة وغير المفتقرة إلى تفسير أو تبرير • إنه

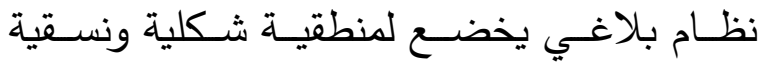
مغلقة، ويكثف عن تورط في دوجماطيقية واضحة

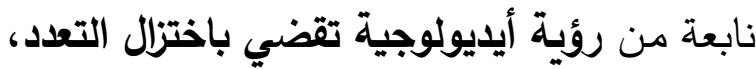

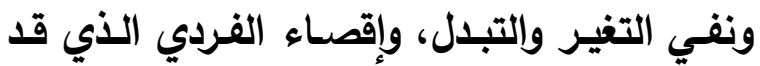

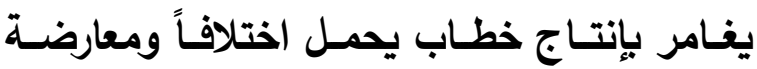
وتمـرداً علــى المبــادئ والأوضــاع والأصــول والمصادرات وغير ذلك من المرجعيات على كافة

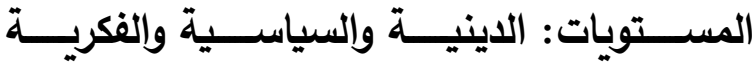
والاجتماعيــة. "... وهــا يعنـي أن الكـائن في لـي

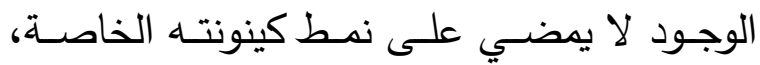
بقدر ما يخضع لنمط انتظام الكون، وبالتالي عليه ألا يكون ذاتـه بقدر مـا هـو حامـل لصـورة هـذا النظـام. وهنـا فـإن بلـوغ كمـال المعنى، ليس إلا فيل

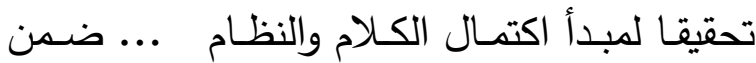
إعادة إنتاج التوافق والنظام."(32) مثل هذا النظام

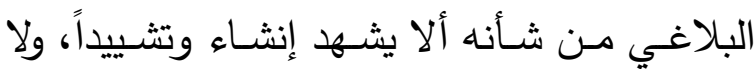

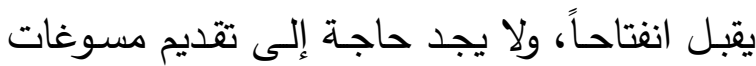
عقلية لجمعه تفاصيل وجزئيات في نسق واحد على نحو ما يقتضيه العلم الحديث.(33) إنه جهاز 
البلاغـة، والتـراث كلـه، مـن راهنيتهـ، وتغرقـه في

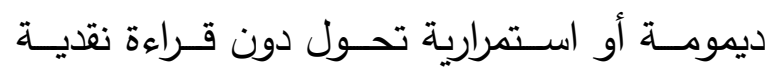

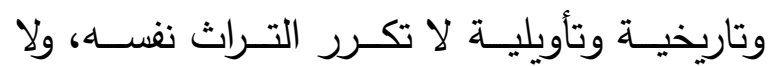
تستنسخه، ولا تحيا في داخله؛ قراءة تكون - كما يصفها محمد عابد الجابري - موضوعية ومعقولية، "فمن جهة تحرص هذه القراءة على جعل المقروء

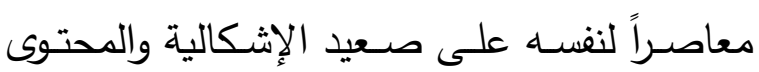
المعرفي والمضمون الأيديولوجي، ومن هنا معناه

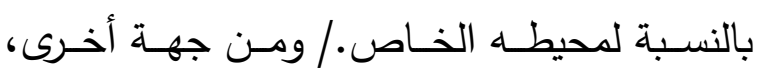
تحاول هذه القراءة أن تجعل المقروء معاصراً لنا، ولكن فقط على صعيد الفهم والمعقولية، ومن هنا

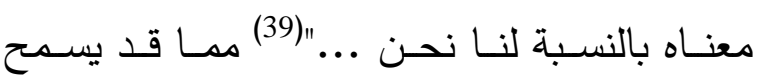
بتوظيفه في تشكيل الهوية أو إعادة بنائها. وهو ما لا يتحقق عند النظر إلى الأشكال البلاغية على لـ ألى أنها بناءات لا-زمنية أو معطى صرف، لا تعني

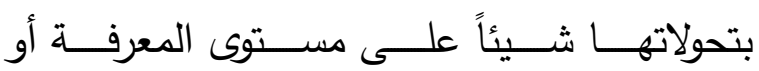
الأيديولوجيا أو الواقع، فصور المعاني ليست سوى تَحَوُل عن الأصل (وضعاً ومعنى)، وصور البيان

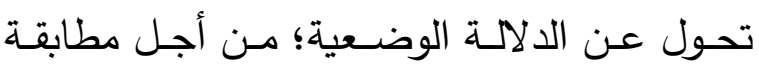
(المعنـى المـراد)، وذلـك في إطـار "... محاولــة

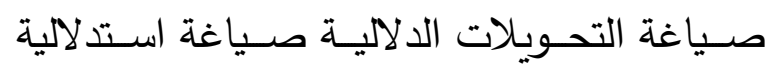
منطقيـة،"(40) تخضــع لقـانون الهويــة أو المطابقــة الذي يقضسي بعلاقة صسورية مثالية بين المعاني/

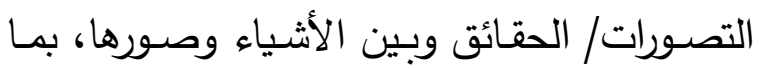
يكثـف عـن وجـود جـوهر ثابـت لمـا هـو متتـوع متغير، في حين أن الهوية ليست انحلالاً للتعددية ولقابليـة التغيـر لصـالح الوحدة والكليـة، بـل هـي حضـــور الاخــتلاف والتتــوع والتعــدد داخــل الاستمرارية والتواصل.
تكون ثابتة وبمنأى عن التغير ؛ هذا السعي يبدو غير علمي تقاومـه حركة الزمن والظواهر الفرديـة والاجتماعيـة والمعطيـات التجربيـة، ومن ثم "...

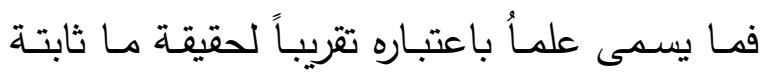

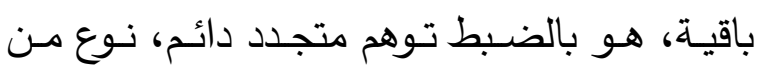

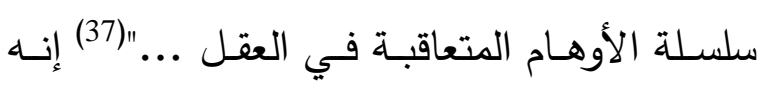
العقـل اللاهـوتي أو الكلامسي الذي يـرى الحقيقـة مطلقة ومتعالية، لا يصنعها البشر ، بل يتلقونها،

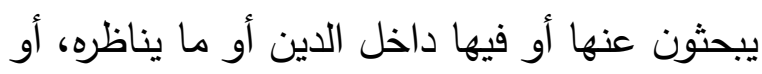
في إطاره. إن الارتباط بالعقل، وتسييجه بالدين، يبدو واضحاً - كما سيأتي بيانـه - في تحديدات كثير من العلماء العرب للبلاغة، وما يستتبع ذلك من فرض استمرارية أو زمنية متعالية ومستبدة علـى المعرفــة وإلمجتمــع، تمــنح المتماثـل أو المتشـابه من الظواهر المتعاقبة وحدة أو كلية، وتبيح اختزال مـا بينها من اختلافات بردها إلحى أصسل سـابق عليها، وتتظر إلى التجديدات في

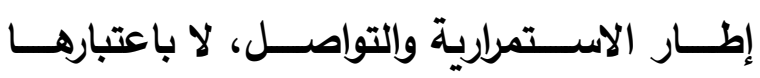
انقطاعـات وإبتكـارات. وفـي ظل هـذا التصـور الفلسـفي، لا تمثل البلاغـة موضـوع معرفـة، ولا

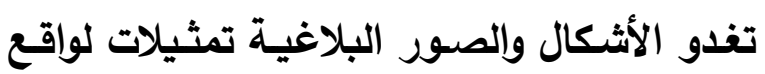
متغير، وأنساقاً للمعنى، أو مظاهر للقصد، وفق هرمنيوطيقا قادرة على دمجها في نسيج منسـم، أي بعبـارة أخـرى: لا تصـبح أشـكالاً "... لمراقبـة

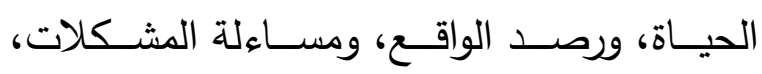

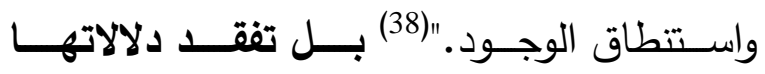
ووظيفتها، وتتحول إلى أنساق مفاهيمية صورية

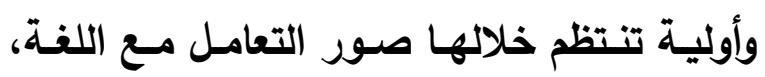
وفق أيـديولوجيا سـائدة ومهيمنــة وثابتـة تجـرد 
626هـ) والقزويني (ت 739هـ)، وكذلك عند أبي

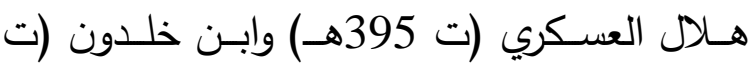
808هـ)، هي حدُّ الإعجاز الذي يُدرك ولا يمكن وصفه، ومُدركِـه هو الذوق الذي يُكتسب بطول خدمة علميّ المعاني والبيان. فالوقوف على مراد الله تعـالى مـن كلامـه، والتعـرض لتفسيره، والعلم بإعجازه من الجهة التي خصـه الله بها، في وفاء الدلالة منه بجميع مقتضيات الأحوال، وفي بلوغه أعلى مراتب الكمال في الكلام - لا سبيل إليه إلا

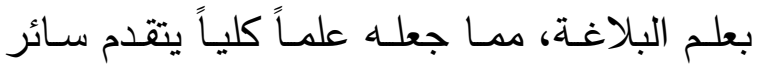

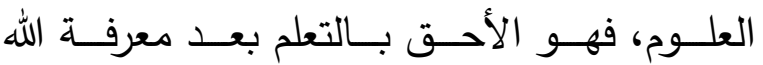

وتوحيده. (42)

وكذلك كان الحال مع ابن البناء المراكثي

(ت 724هـ)، فقد اتصفت البلاغـة، أو بـالأحرى البيـان، وقوانينه(ـا) عنده بالكليـة، لتعلق البيـان بالعقل الذي يفْضُل به الإنسان ويتميز عن سائر

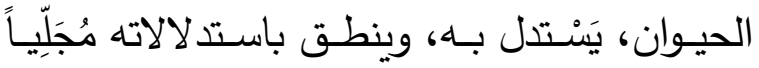

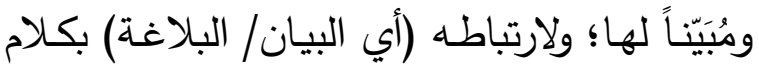
الله تعـالى، القرآن الكريم، الذي هو ".... للنـاس بيـان، ولكـل شـيء تبيـان، قَصُسرَتْ دون بلاغتـهـ وبراعته الفُهوم، وانحصرت تحت كلياته وجزئياته جميع العلوم ... فقامت به الحجة، وتمت علينا به

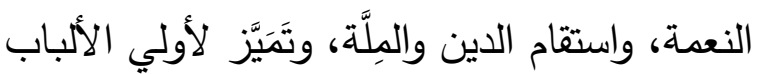

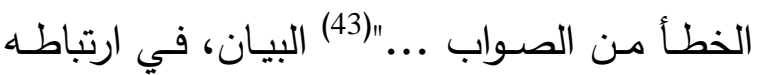
بقيام الحجـة وتمام النعــة واستقامة الدين والملـة وتمييز الصواب، هو ملكة أو مِنَّة أو فيض إلهي الهي على الإنسان، هو سبيل معرفة البيان الإلهي، أي كليات القرآن وجزئياته التي شملت جميع المعارف والحقائق؛ سبيل معرفة حكمة الله ومقاصده ومراده
يبدو إذن مأزق البلاغة العربية، ليس في

نزوعها إلى الكلية، وإصرارها على بنـاء نمـاذج

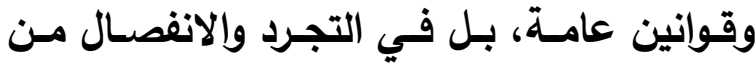
سياقاتها المتغيرة تاريخياً وأيديولوجياً، وافتراض أنها معرفـة نسـقية، مؤلفـة مـن قضـايا منطقيـة تعبر عن فرضيات، تجتمع فيها الظواهر وفق علاقـات التـرابط والاتســاق التــي تمثـل شــروطاً داخليـة، دون الالتفـات إلـى السـياق التـاريخي والحضــاري، وتغيـر نسـق القـيم العـام؛ ودون

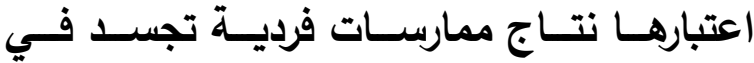

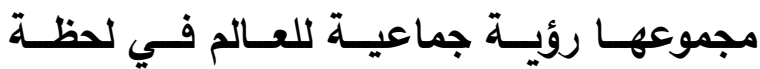
حضـارية محسدة، أي دون النظـر إليهـا ضــن نسـقية سـيميائية دالــة مرتبطــة بتـاريخ الجماعــة وتحولات أنساقها القيمية وأشكالها التعبيرية، إذ لم تكن الممارسات والاستعمالات الفردية، في تصور البلاغيـين العـرب، سـوى تجسـيد لنمـوذج عـام نمطي، مصــاغ وفق شـروط واعتبـارات منطقيـة وعقلية، فالنموذج يختزل الفردي، ويحدد مقبوليته، والفردي بدوره هو استكناه لإمكانات النموذج؛ أو

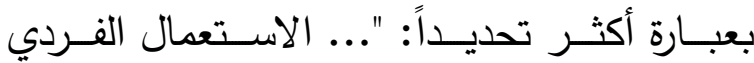
المخصوص للغـة هو استبطان للغـة وانتهاء بها

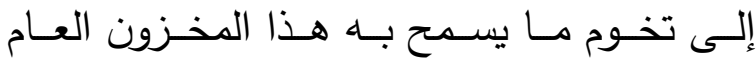

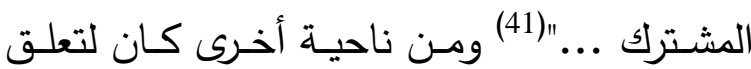

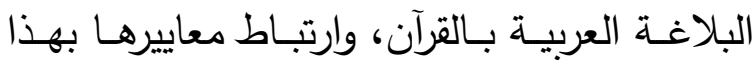
الـنمط أو المستوى الرفيع مـن القـول، أي الكـلام الإلهـي الــي تقـف دونــهـ كـل أشـكال التعبيـر الإنساني؛ كـان لـه أثره في تحسر البلاغـة مسن التاريخ ومسن أيديولوجيات عصسورها المتعاقبة.

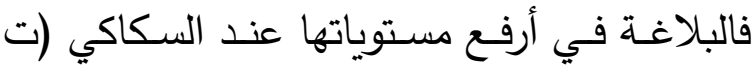


البديع. فالبيان معرفة كلية شمولية يدركها العقل

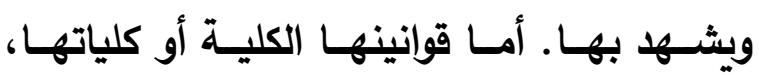
ووجوه المعنى الكلي أو المقصود وجزئياته غير المحصسورة مسن حيـ هـي في ذاتهـا ببـاهتها وتعلقها بحقائق الأمور، لا باعتبار تحققها لفظاً - فهذا هو علم البيان، في حين أن ما يعطي أو يكشف تمظهرات هذه القوانين الكلية وتجلياتها الجزئية، ما يمثل كيفيات القول وطرق الاستدلال على المعنى أو الغـرض بالألفـاظ، والقواعـ أو المقولات العامـة الكليـة التي تجعل مـن الألفـاظ دليلاً ودلالـة على المعنى أو الغرض المقصود، وتُمَكِنِ له في النفس - فهذه هي صناعة البديع أو صـناعة البيـان. هذا التمييز مـن جانب ابـن البناء، والذي لا يخلو من تداخل يتجاوب مـ مـا عُرف فـي التـراث العلمـي العربـي مـن التبـاس

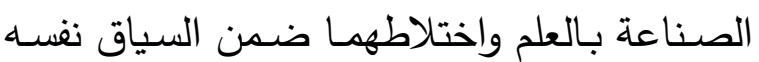
الـذي يشـير إلـى تمايزهمـا مـا بـين وعسي نظـري وإجـراء عملـي (47) - يـدمج البلاغـة (والفصـاحة) بصناعة مستندة إلى علم كلي وإلى قواعد وأصول كلية عامة يراها هو وافية ومنضبطة لدرء التخالف فـي الكليـات دون الأجنـاس والأســماء والصــور الجزئية، تحيط بطرق إنتاج المعنى وفهمه بألفاظ وأساليب تدل عليه وتطابقه، فتجعله واضحاً قريباً متمكناً بحسب أغراض الخطاب، على نحو ما يقع "... في كتاب الله وسُنَّنة نبيـه، وفي المخاطبـات

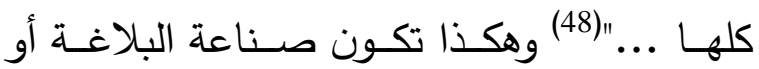
البديع شـاملة لكل طرق القول وما تدل عليـه من الأحوال والأغراض: سواء تلك التي تُستعمل في طريق الحق، ويحصل بها اليقين أو الظن الغالب
من الخلق، وبـهـ تُستخرج الحقائق، ويُتوصـل إلى معرفــة الخلائـق - بعبــارة الكُلاعـي الأثــبيلي

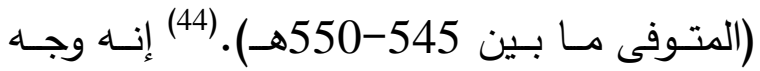
الدلالتة والدليل وَجِهَةُ المعنى التي لا تتحصـر ولا يُحاط بها. ف"... البيان هو شيء يُفيضده الحق من

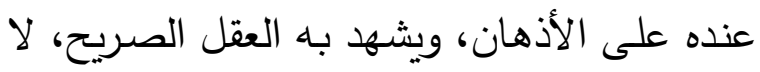
باستفادة من إنسـان. إنمـا يحصـل من المخلوقين التتبيـهـ علـى العلـم الذي علمـهـ الله خلقـهـ ..."(45) البيان بذلك معرقـة طريقها العقل، تتحصـل بعلم كلي يتعلق بـإدراك الكليات (والجزئيات)، وقوانينهـ لذلك كلية مشتركة، عبر صناعة مستندة إلى هذا

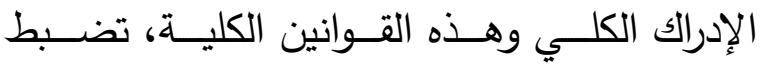
بقواعدها وأصــولها، التي تغـدو بالضـرورة كليـة، الجزئيات التي تتدرج تحت القوانين العامـة. إنها صـناعة الكـلام أو القـول وطبقاتـه ودلالتـه على المعنى المقصـود، مـن جهـة الاسـتـلال بالألفـاظ على معانيهـا، فهـي ترجـع إلى كيفيـات العبـارة والأســاليب، أي كيفيـات تحقـق المعرفــة الكليــة بـالقوانين وتطبيقها؛ هـذه الصـناعة هـي صـناعة البـديع أو صــناعة البيـان (التـي تـدخل فيهــا الفصـاحة والبلاغـة، حيث الفصـاحة هي مشـاكلة الألفاظ للمعانى ودلالتها عليها بمقتضى خواص تتعلق بمخارجها ومبانيها وتصور معانيها، والتي ترجع إلى اعتبارات عقليـة منطقيـة هي المشـاكلة العقلية والنظام الطبيعي واتساع الفهم في لوازمها؛ وحيـث البلاغـة هـي التعبيـر عـن المعنـى بمــا يطابقـه، فيؤدي إلى حصـوله في النفس، وتمكنهـ من الغرض المقصود (46)). وهكذا يميز ابن البناء بين: البيان، علم البيان، صناعة البيان أو صناعة 
الــي شـكله العمـل على إقـرار النزعـة العقلانيـة البرهانيـة في الثقافـة العربيـة الإسـلامية، مـن قبـل فلاسفة الأندلس والمغرب على وجـه الخصوص؛ لمـا يحققــه البرهـان مـن بنــاء للحقيقــة والمعرفـة

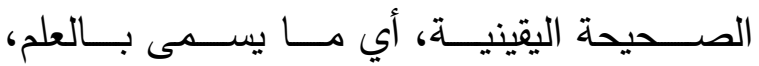
بـالانطلاق مسن 》الكليـاته التـي تُعـد أسـباباً أو علـلاً أولـى أو مبـادئ وأصـولاً ترجـع إلـى العقـل نفسـه بمـا هو متلَكَة إدراك الأثشياء بأسبـابها، أو تستفاد من معطيات التجربـة بواسطة الاستقراء الأي يمكّن من إرجاع الجزئيات إلى كليات، ومن رد الكثرة إلى الوحدة؛ فتتحقق المطابقة بين كليات العلم ونظـام الموضـوعات التي يدرسـها كمـا هي معطاة، حتى وإن تخلفت بعض الموضسوعات أو الجزئيـات عـن مقتضـى الكلـي الذي ثبــ، إذ لا يخرجه عن كونـه كلياً - على حد عبارة الثاطبي (ت790هـ). (52) جـاءت هـذه النزعــة البرهانيــة لمواجهـة مـا يمكـن أن يسـمى النزعـة البيانيـة

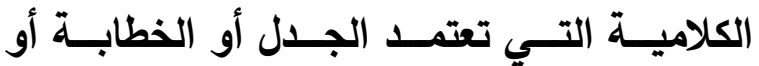
المغالطـة، ضــن مجـال مـا هـو محتمـل وظنـي، وهـدفها هـو الإقتـاع والتـأثير، لا إقـرار الحقيقـة واليقين، في مقابـل النزعـة البرهانيـة التي كانت "... تطلـب اليقـين فـي العقليـات، والقطــع في في الفقهيات، والمطابقة لطبائع العمران في المرويات التاريخيـة، معتمـدة في بنـاء المعقوليـة في هـذه الميـادين المعرفيـة على الانطـلاق مـن الكليـات واعتبار الأسـباب والمقاصـد. إنها نزعـة علميـة بـالمعنى الـذي كـان يفهـم بـهـ العلـم فـي القـرون الوسـطى - قامــت كثـورة على مـا سـاد الثقافـة العربيـة مـن نظـرة تجزئيـة، ومشــادات كلاميـة،
أو الإقنـاع (البرهـان، الجدل، الخطابـة)، أو تلـك الخارجة عن باب العلم الداخلة في باب الجهل أي تلك التي تكون كاذبـة بإيقاع التخييل والتوهم أو الغلـط والإبطــال (الثــعر ، المغالطــة)؛ أو سـواء تتتمي إلى الحكمة أو إلى الثعر ، أو إلى الجد أو إلى الهزل. فجميعها - وفقاً لسعي ابن البناء تشترك في الصناعة وقوانينها التي "... يستخدمها كـلُّ بحسـب أغراضــه ومقاصــده: مـن النبـي إلـى

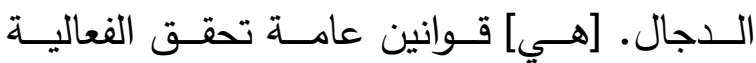
والنجاعة بقطع النظر عن جهتها المعرفية، قوانين تثـــل أنــواع المخاطبــات المشــروعة بالــدين، والمشـــروعة بالتـــداول وبضـــرورة الأعــــراف العمليـة."(49) هـذا المفهـوم النسـقي للبلاغـة الذي لـي يثـــل الاسـتـلال والتخييـل والحجـاج والتـداول لا يمكـن أن تحـيط بـه علـوم أو صــناعات اللسـان الجزئيـة - كمـا جـاء سـابقاً على لســان حـازم القرطلـاجني، بـل هو شـان صـناعة كلية، قوانينهـا مقولات أو أقاويل كلية جامعـة لجميع مـا وضسعت له أو لأكثره.(50) وهي لا تكون كذلك - كما يُفهم مـن كـلام جـازم القرطـاجني عـن مرقـاة البلاغــة المعضـودة بالأصــول المنطقيـة والحكميـة - مـن دون "... محتـوى وجـودي (أنطولـوجي) ومعرفي عـن 》الأثــياء الموجـودة فـي الأعيـانه وعـن علاقات »الصور الذهنية/ بهذه الأشياء ..."(51)، ومـا يـتحكم في هـذه الصـور أو التصـورات مـن قوانين ومبادئ عامة. لم بكن ابن البناء في انشغاله بكليات العلم أو الصناعة، شأنه شأن العلماء والفلاسفة العرب، منفصـلًً عن ذلك المحتوى الأنطولوجي والمعرفي 
باتجاه التوفيق بين الفكر الأرسطي والعربي: "...

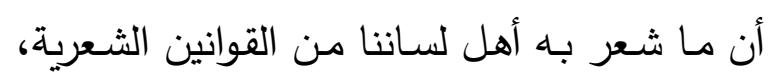

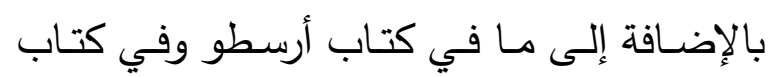
الخطابة، نزر يسير - كما يقوله أبو نصر • وليس اليس وفي

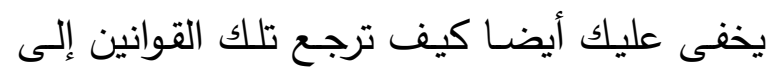

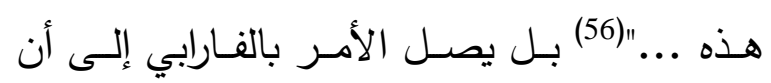

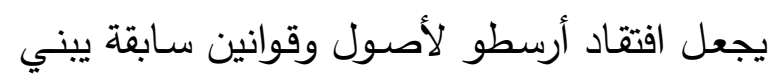

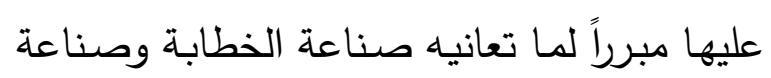

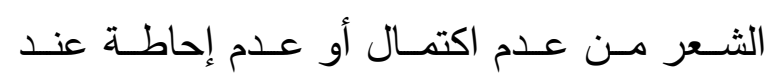
أرسطو، ربما لم يتطلع إليها لهذا السبب. (57) كانت البلاغة/ البديع عند ابن البناء بحثاً

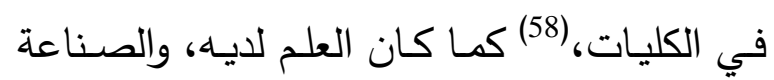

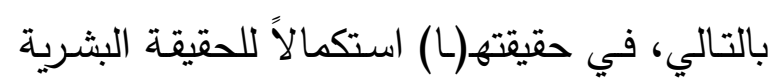

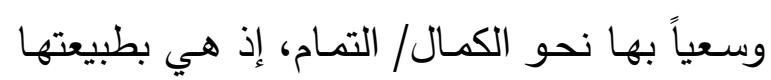

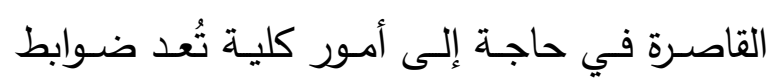
للنظر في مراتب الإدراك البشري الثلاثة: مرتبـة الحس، مرتبة الخيال، مرتبة العقل. هذه الأمور

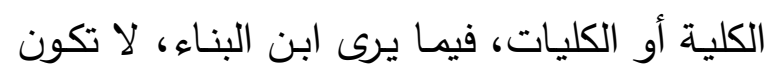

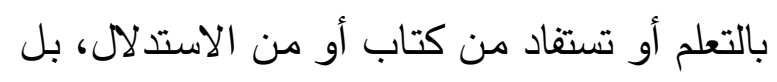

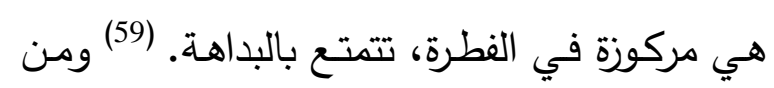
هنا كان البحث في الكليات، والعمل على تقريبها، واختصارها، وضبطها من جانب ابن البناء - هو في حقيقته ضبط وتقنين وتحكم في عمليات إنتاج المعنى وفهـهـ وتأويله في المخاطبات كلها، بمـا

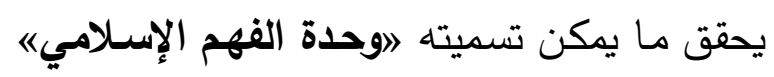

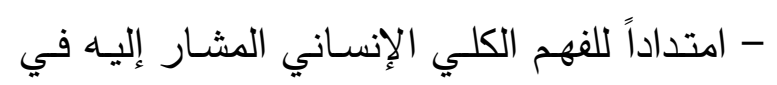

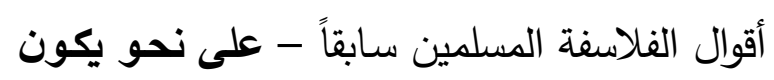

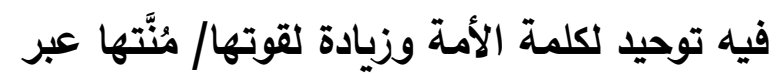
خطاب يفي بأغراضه ووظائفه في الحياة العامـة،
وخلافات فقهية تعتمد المغالطة والجدل."(53) وفي ظل السعي نحو بناء معرفة علمية برهانية تمتد

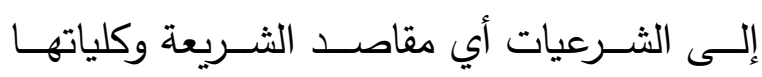
المستمدة من حكمة الله تعالى التي ضمنها كتابه

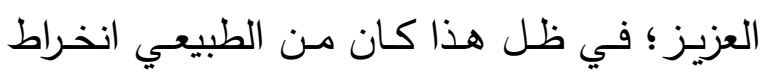

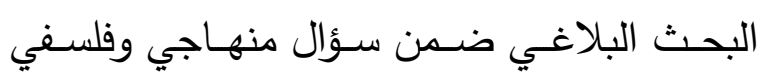
يتعلق بصياغة المبادئ والقوانين والمفاهيم الكلية المشتركة، المستمدة مـن منطق أرسطو وفلسفته ولئه وشعريته، والعمل على التدليل لها بالأمثلة العربية. حدث هذا - على نحو ما تظهره عناوين عدد من

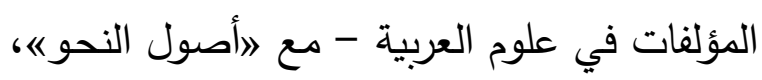

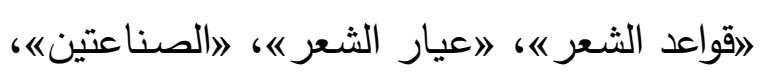
》صـناعة البديع) ... إلـخ . فقد أدرك المفكرون والفلاسفة العرب في بحثهم عن القوانين الكلية،

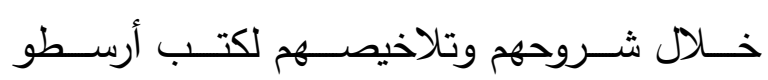

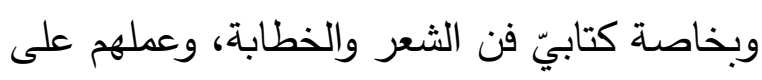

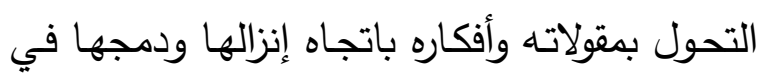
الثتافة العربية الإسـلامية؛ أدركوا أن هذه القوانين الكلية هي عامة ومشتركة لجميع الأمم أو أكثرها، ولجميع المخاطبات بما في ذلك الخطاب التخييلي

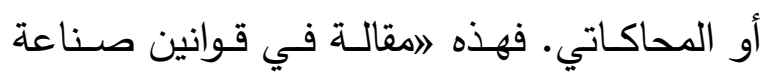

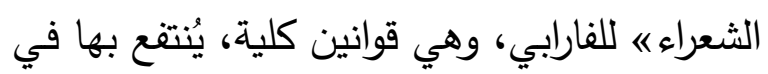

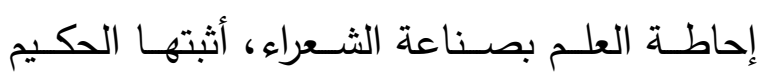

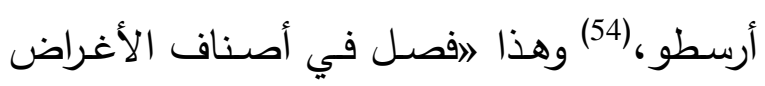

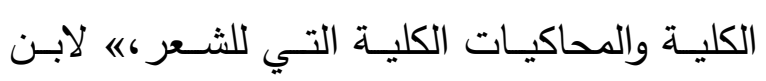

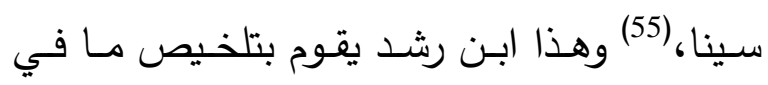
كتاب أرسطاطاليس في الثعر من القوانين الكلية

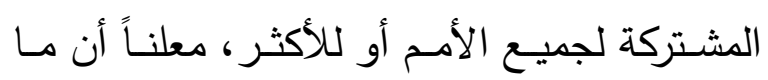

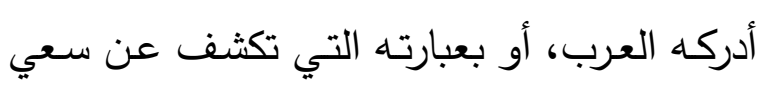


بإجراء الاستقراء بحسب اعتبار كل واضع لصفات مشـتركة لتلك الصـور الجزئيـة، ولمـا يختـاره مـن تسميات. هذه الأمثلة والصور الجزئية التي يتفق ابـن البنـاء فـي كثيـر منهـا مـع ســابقيه مسن البلاغيين تمثل عناصر في نسق بلاغي سـائد ومهيمن لم يشـأ ابن البنـاء أن يستعيده أو يـذكِر يـر به - وإن رجع إلى جانب من تاريخه السـابق من خـلال إشـارات إلىى: سِـرّ الفصـاحة، النكـت في إعجـــاز القــرآن، الصـــناعتين، العدــــة، البيــان والتبيين، كتاب البديع، حلية المحاضرة، وإلى كثير مدا ورد بها من شواهد (62) - لتطلعهد إلى تجاوزه وتأسيس نسق بلاغي مغاير استتاداً إلى تصـور كلي معضود بمقولات منطقية ورياضية، بما يؤكد مجدداً الطـابع العـام الإنسـاني أو الكوني لنسـقه، ويسمح بإعادة قراءته - في تشابهاته واختلافاته ضــن الدرس البلاغي المعاصـر الذي هـو في حقيقتــه "... تطـوير للتـراث البلاغـي والثــعري والمنطقي الموروث من اليونان والرومان والعرب، ولمها دار حـول هـا التـراث مـن شـروح وهـوامش ..."(63)؛ وفـي إطــار الإبسـتيمولوجيا المعاصــرة بانفتاحهـا وتتوعهـا، مـن أجـل بنـاء نظريـة عربيـة معاصرة لها فضاءها المعرفي الذي يشكله الانفتاح عـى العـــوم والنظريـات المســــدثة، والارتبـاط بـالواقع العربــي: الثقــافي والأدبــي وإثــكالياته ومتطلباته وإنجازاته وصياغاته، إلى جانب الفهم الموضوعي والمعقول للتراث. يتجــهـ ابـن البنــاء، خلافــاً لســابقيه مـن البلاغيين، إلى إدراج الصور الجزئية تحت كليات عامة، مما استدعي قيامه بعملية تصنيف موسعة
وفـي أمسور العقيـدة مسن خـلال فهـم أو تأويـل صحيح للقرآن والسنة. ".. فغرضسي أن أقرب في هـا الكتـاب مـن أصـول صـناعة البـديع،/ومـن أساليبها البلاغية ووجوه التقريع، تقريباً غير مُخِلّ، وتأليفـاً غيـر مُمِلَّ ... ومنفعتـهـ في زيـادة المُنَّة،

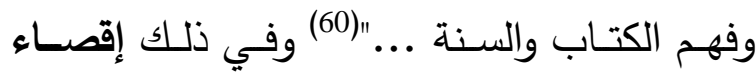
للممكنات، ونفي لأي تجاوز أو خروج محتمل أو إطاحـة بالنســق المقتـرح، ومــن ثــــ لا مجــال للاختلافـات، أو الاحتمـالات، إلا باعتبـارات مـن داخل الكليات. فلما كانت كل صناعة لها مبادئ، كان من الواجب على الناظر في تلك الصناعة وفقـاً لعبـارة ابـن رشـد - أن يسـلم مبادئهـا، ولا يتعـرض لهـا بنفي ولا إبطـال، أو كمـا يقول ابـن البنــاء بشــأن البلاغــة أو صــناعة البــديع: "... يختلف أهل هذه الصـناعة في الأمثلـة الجزئيـة، فيضـعها بعضـهم في قسم، ويضـعها آخرون في قسم آخر . كما يختلفون أيضـاً في أسامي الأقسام وفي عددها وفي تفاصيلها ... وليس ذلك مخلاً بالصـناعة ... فـلا يضـر الاختلاف في إدراجها تحـ أي كلـي كـان، ولا تسـميتها بـأي اسـ كـان ..." وهـو مـا يسـتتبع حصـر الجزئيـات، أي لي الأمثلة والشواهد لاسيما الشعرية، وظيفياً في بيان الثكل أو المصطلح البلاغي، أي في كونها مجرد اسـتـلالات لا تمثـل تقاطعاتهـا وتـداخلها مجـالاً خصـباً للتأويـل، ولا تعنـي بتكراريتهـا أكثر مـن جاهزيتها، ومن ثم فهي تأتي كثيراً غير منسوبـة إلى قائليها؛ هذا إلى جانب إقرار ابن البناء بوقوع الاشـتراك والترادف في كثير مـن أسـماء الصـور الجزئية/ المصطلحات في ظل أخذ أهل الصناعة 
ودلالـة المفهوم ودلالـة المعقول؛ وأقسـام كل قسـ مـن أقتسام اللفـظ باعتبـار كـل قسـم مـن أقسـام المعنى: لفظ مفرد يدل على معنى مفرد، ولفظ مفرد يـل على معنى مركب، ولفظ مركب يدل على معنى مفرد، ولفظ مركب يدل على معنى

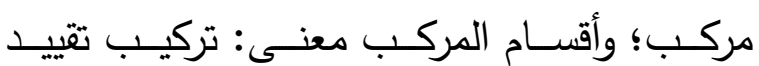
واشـتراط، تركيـب طلب، التتبيـه، الإخبـار الـذي ترهي ينقسم إلى: جازم وغير جازم، كما ينقسم من جهة العقل إلىى: واجب أو ممتتـع او ممكن، والممكن ينقسم إلى: ما وقع، ما لا يقع، ما سيقع قطعاً، ما يُقَدَّر واقعـاً، مـا هـو مجهـول الحـال في علمنــا؛ وأقسام المعاني: من حيث هي في الأذهان فقط، أو في الأعيان خـارج النفس، أو مـن حيث هي التهي حقائق فقط، لا بالنسبة إلى ذهن ولا إلى خـارج

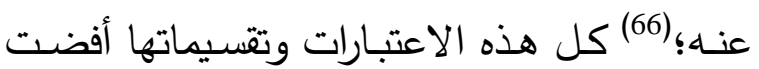
بابن البناء إلى كليتين تستوعبان صـناعة البديع بقوانينها وصورها الجزئية، وهما: أقسام اللفظ من جهة دلالته على المعنى، وأقسـام اللفظ من جهـة مواجهـة المعنى نحو الغرض المقصـود. متفاديـاً بذلك استقلال اللفظ عن المعنى، والتباس الغرض بالمعنى، وإمكانيـة استخلاص الغرض مسن دون عمليـات تفسـيرية مسن قبيـل التحليـل والمقارنــة والاستبدال. وأولى هـاتين الكليتين تختص بشكل القول أو الخطاب أو المخاطبات - أو مـا يمكن أن يسـى شكل التعبيـر بمصـطلحات هيلمسـيف L. Hjelmslev وتثـكلها في الخطـاب أو مـا يشـبه البنيـة العليـا المتعلقة بشكل الخطاب(67) - متجلية في مقولات أو قوانين تتعلق بالاختزال ومقابله: أي الإطالة أو
تعتمد الآليات المنطقية والرياضية مثل: التجنيس، التقسـيم، النسـبة أو التتاسـب؛ لينتهي إلى تحديد شـامل لتــك الصــور ، أو بـالأحرى محاصـرتها، وبالتالي وضـع ضـوابط لإنتاج المعنى، ومحاصـرة طرقه وآليات تأويله، والسيطرة عليه؛ دفعاً لأي فهم أو تأويل يثير خلافاً وتفرقاً أو التباساً أو تعدداً أو شـططاً، كـذلك الـذي أنتجتهـه صــياغة الأنسـاق البلاغية السابقة عليه، باعتمادها استقراء وتصنيفاً غير مبنيين على مبادئ كلية عامة. وينطلـق ابـن البنـاء فـي تأسيسـه لكلياتــهـ وقوانينه البلاغية العامة من فهمه لصناعة البديع/ البلاغـة بوصـفها صــناعة القـول ودلالتـهـه علـى المعنى المقصسود، بعبارة يسهل بها حصـوله في

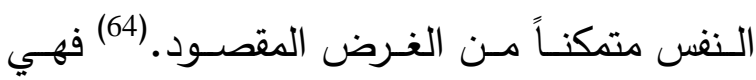
صناعة عمادها الدلالة بالقول/اللفظ على القصد أو الغرض، أي اعتبار العلاقة بين اللفظ والمعنى،

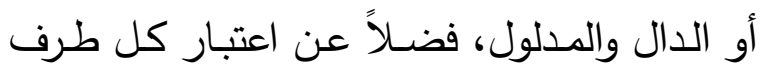
في ذاته: مفرداً ومركباً، اشتقاقاً وتركيباً ... إلخ، حيث "... يُعتبر اللفظ بالنسبة إلى المعنى مـن جهـة دلالتـه عليـه، ويُعتبـر المعنـى بالنسـبة إلىى اللفـظ مـن جهـة مـا هـو مـدلول اللفـظ. وهـذان

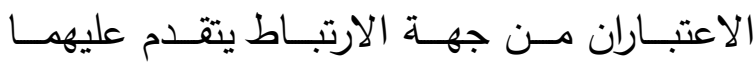
بالضـرورة اعتبـار كل واحـد منههـا في نفسـه، إذ الارتبـاط بينهمـا بنسـبة متـأخرة عـن ذاتيهــا في الوجود..."(65) هذه الاعتبارات المتداولة في أوساط الأصسوليين والمتكلمين والفلاسفة والبلاغيين، ومـا تخضـع لله من تقسيمات: أقسام دلالة اللفظ على المعنى من جهة أصل الوضع: المطابقة والتضمن واللـزوم، ومـن جهـة التخاطـب: دلالــة المنطــوق 
متناسِبة، أي لا مناسَبة بين طرفيها، في حين أن جميـع الاسـتعارات، وفـق قـوانين ابـن البنـاء في النسبة أو العلاقة، إنما هي إبدالات في المتتاسبة. "والأشياء المتتاسبة إذا بُدِّلت تبقى متناسبة، فتكون إن نسبة الأول للثالث، كنسبة الثاني للرابع. وكذلك

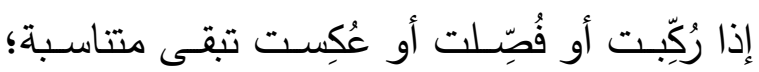
ولــلك يـدخلها الإبـدال والحـذف ..."(69) وهكـذا يكون صـحيح الإبـدال في المتناسبة كذلك الذي في: نسبة الإيمان إلى الكفر كالنور إلى الظلمة:

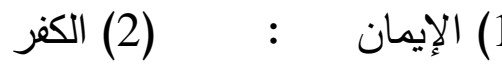

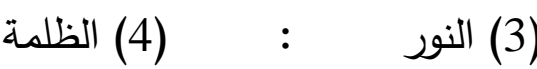
والإبدالات المحتملـة والمقبولتة إذن: الإيمـان نور ، الكفر ظلمـة، نور الإيمـان، ظلمـة الكفر • ونظير

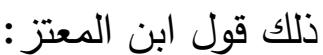

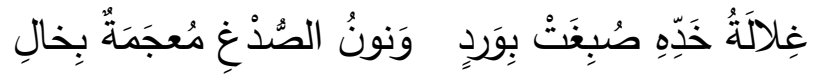
"ونسبة خده إلى حُمْرته كنسبة الغلالة إلى صبغها بالورد، ونسبة صدغه إلى خاله كنسبة النون إلى

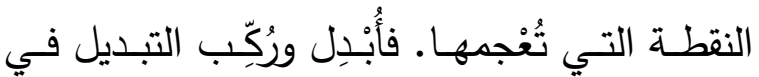
النسبة."(70) ووفق هذا التبديل في النسبة لم تأتِ تلك الأقوال الاستعارية الفاسدة، كما أنها لم تتبع، فيمـا وقـع فيهـا مـن حـذف، الصــور الممكنـة للإبدال. (71) وإن كان ابن البناء نفسـ يعترف بأن التبـديل لا يستلزم بالضـرورة دائمـاً حضـور نسبة،

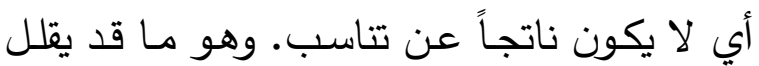
من اتهام ابن البناء بالتعسف في إدراج الجزئيات وإخضاعها لهذا القانون أو ذالك من قوانينه الكلية. فربما يعود الاعتراف من جانبه إلى إدراك لصعوبة

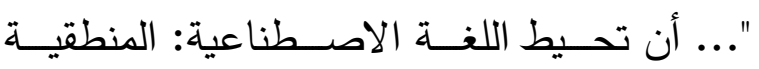

والرياضية بكل التعابير للغة الطبيعية."(72)
الإطنــاب، أوردهــا ابـن البنـاء تحــت تسـميات: الإيجاز والاختصار ، الإكثار ، التكرير (الذي يمكن أن يُدرج ضـــن الإكثار )؛ بينمـا تخـتص الكليـة الثانيـة بشـكل المحتـوى أو الأبنيـة الكبـرى في لإني الخطاب، أي بالقوانين التي تحكم العلاقات بين الكائنـات والكيانـات، التي يتشـكل بهـا الغـرض المقصـــود مــن الخطــاب ويتجلــى محتــواه أو مضــونـه. وهذه القوانين كمـا يوردهـا ابـن البنـاء هي: الخروج من شسيء إلى شيء، تشبياه شيء بشيء، تبديل شيء بشيء. تفصيل شيء بشيء.

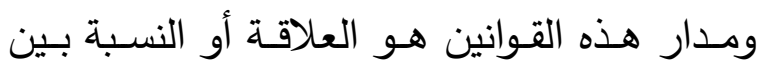

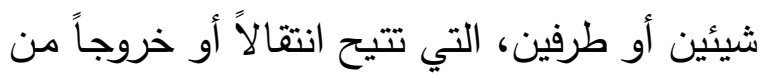

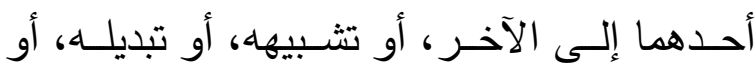

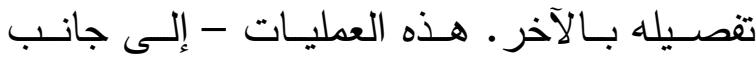
عمليتـيّ الاختـزال والإطنـاب - بمـا هـي قـوانين تفسيرية وتصنيفية لطرق إنتاج الأشكال البلاغية التي تتجلى فيها الأغراض، تلتقي مـع تصنيفات الأشكال وتأثيراتها المرتبطة بتقديم المعلومات عند

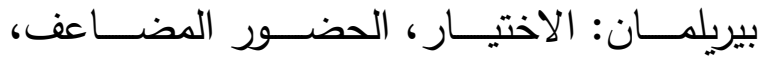
الاتصــال بـالمتلقي؛ كمــا تلتقـي مــع العمليـات المقترحسة مـن جانـب جماعـة مـو، وفـان دايـك: الإضـافة، الحذف، القلب، الاستبدال. (68)وقد أراد ابن البنـاء لقوانينـه أن تكون شـاملة وكلية، تحكم الكائن والمحتمل من أشكال القول والمعنى، وتقدم في ذلك تفسيراً منطقياً لم يألفهـ البلاغيون كثيراً أما ما لا يخضع لهذه القوانين فهو محكوم عليه بالفساد. فأقوال من قبيل: 》امَناخِر البدر ش، 》هـاء

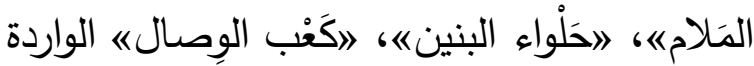

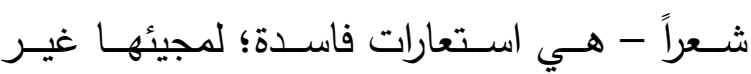


يحكمه دوران الأشياء/ الأمثلة وعودتها وتكرارهـا واستتسـاخها دون أن تغدو تمـاثلاً تامـاً أو نُسَخـاً مطابقة للأصل، إذ هو تشابه نتيجة التصرف في

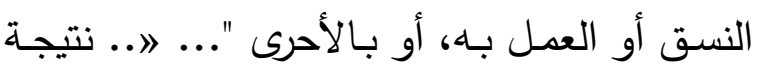
عمل النسـق ونشـاطه كمعلول ومفعول، لا كعلـة وشرطه ..."(73)؛ ولا يشكل المشروع جديداً لأن ما لأنسا يقدمسه ابن البناء من فروض تفسيرية لا يذهب

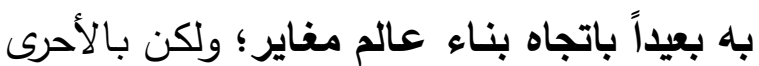

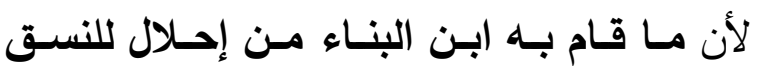
البرهاني الرياضـي محل النسق البياني الكلامس، متسقاً مـع ثقافة عصره ومتطلباته، لـ يـنجُ هو الآخـر مسن صسياغة معياريــة: ثابتــة ومتعاليـة للبلاغة، بل لعلها أكثر صرامة وتحكمـاً، استبدلت بمتعاليـات الأثـكال والصـور البلاغيـة متعاليـات الكليـات والقوانين العامـة، على نحو تبدو أنها إعـادة إنتـاج لأيـديولوجيا قديمسة متوارثـة تتسـتر وراء هـاجس المغـايرة، أو هـي محاولـة لتحديث الفكر البلاغي تسـللت إليها الـروح ذاتها التي شكلت السائد والمهيمن. فصياغة ابن البناء هي الأخـرى تصــطنع سـلطة مرجعيـة، وهـي سـلطة

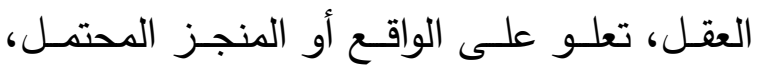

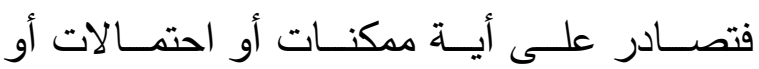

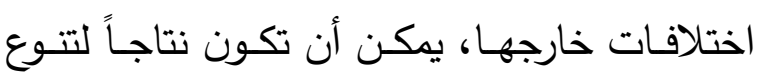
التجـــارب والممارســـات، والســـاقات التاريخيــــة والحضارية، والقيم الاجتماعية والأيديولوجية. إنها تكريس لوجـود السـائد وهيمنتـه، ولـدعوى الالتـزام بنموذج أمثل في القول/ الخطاب، وفي الحياة، عبر وسائل محددة ومقبولة ومقررة، فلا مجال إذن في مثل هـذه الصـياغات للحديث عـن بنـاءات
كــان لابــن البنـاء مشـروعه البلاغــي الخاص الذي يختلف عن نموذج السكاكي، وهو في ذلك يمثل مرحلـة مـن مراحل تطور البلاغـة العربية، فلم ينقطع اتصـاله بالتراث المشترك بينـه وبـين السـكاكي - مــع حصــول اخـتلاف فـي مصـادريهما، في الوقت الذي كـان فيـه استجابة لمتطلبـات عصـره واحتياجاته، حيـث ارتبط ابـن البنـاء بالسـياق الفكري والثتـافي العـام السـائد في بيئته وعصره، فكان هدفه من مشروعد أن يجعل مـن البلاغـة علمـاً بـالمعنى البرهـاني، لتلحق في ذلك بالعلوم الطبيعية أو الصناعية في بحثها عن القوانين العامـة الكليـة والثـاملة، وإنتاجهـا معرفـة صـحيحة يقينيـة. وهـو مــا يتحقـق فـي البلاغـة بإيجـاد كليـات ومعـايير عامــة تضــم الظـواهر الجزئيـة، وتعــ نوعـاً مسن تفسـيرها أو تعليلهـا منطقياً، تهدف إلى إنتاج المعنى الصحيح وبناء الحقيقــة، بـدلاً مـن أن تكـون عرضــاً للصــور والأمثلـة، وتكهنـاً بالقصسود والمـرادات التـي هـي أمسـور نفسـية لا تخضـــع للمعرفــة العقلانيــة والسببية. غير أن مشـروع ابن البناء، مـع تميزه عن مشـاريع غيره مـن البلاغيين ونمـاذجهم، لا يشكل نسقاً جديداً بالمعنى الدقيق، ليس لما يحمله بداخله مـن طبقـات وروابـط بالقـديم السـائد (مـا قبـل -

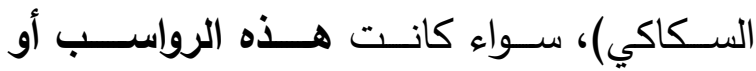
الارتباطـات والتشــابهات، وخاصــة فيمـا يتعلـق بالأمثلـة والصـور الجزئية، تمثل إقراراً أو تبريـراً لاثثعورياً بسطوة النسق السائد، أو تنتمي إلى ما يســى بعـالم السـيميولاكر simulacre الـذي 
وبأهميـة اسـتعادة البلاغـة لوظيفتهـا الحجاجيـة التي لم يعدد ابن البناء إلى إبرازها، حيث يتراجع البعد الحجاجي في مشروعاه، كما هو الحال مع السجماسي (ت 730هـ) صاحب المنزع البديع في تجنيس أسـاليب البديع، أمسام النـزوع نحو كليات الصــناعة، ومــا تقتضـيه مـن تأسـيس منطـق التوافـق والائـتـلاف الـــي لـيس بحاجـة إلــى التفــاوض، ولا يعتــرف بــالمتغير والاحتمــالي والـــاتي؛ ممــا يقلـل والحالـة هـذه مـن إمكانـات الانطـلاق منهمـا نحـو تحديث البلاغـة. ذلك أن الفعل البلاغي هو في حقيقته فعل تداولي ينهض على اخـتلاف الآراء وتعارضــها داخـل الخطــاب الطبيعــي للغــــة بمنطقهــــا الــــاخلي وإمكاناتهــــا الاستد لالية والبلاغية والجمالية التي تشكل منظوراً للحقيقة، حيث تصـاغ عبرهـا الأفكار والتصـورات وآفـاق التواصـل، ويُمـارس فعـل الإقنـاع، وهـو مـا يجعل من الفعل البلاغي فعـلاً حجاجياً لا تكون البلاغـة في غيابـه أو إقصـائه "... سـوى مجـرد تقنية بسيطة للتواصل. وهذا ما أدي إلى انحطاط البلاغـة القديمــة، وتحولهــا التـدريجي مـن تقنيـة للإقناع، إلى بلاغة للصور ، بلاغة للتحسين، وفي أحسـن الأحـوال بلاغـة أدبيـة خالصــة."(74)، أي لي بلاغة شكلية محضة، تكف فيها الأشكال البلاغية عـن أن تكـون بنـاءات لغوبـة وخطابيـة تـنهض بوظيفتها الإقناعيـة/ الحجاجيـة والتأثيريـة، ويكون لها فعاليتها الاجتماعية، بما هي أشكال تمثيلية للواقـع، وتـأويلات للـذات والحقيقـة والتـاريخ، ممـا يؤكد ضرورة إدراج المكون الحجاجي التداولي في أي مشروع لتحديث البلاغة، بما في ذلك البلاغة
جديـدة أو بـدائل، بـل عـن إبـدالات وتحـولات تم الاعتـراف بقيمتهـا الثـكلية تاريخيـاً، في مقابـل تهميش قيمتهـا المعرفيـة والعمليـة أو التطبيقيـة على الأقل على المستوى البلاغي، ولم تخلُ مـع ذلك، وربما نتيجة له، من إثارة إشكالات وتساؤلات منهجية، ومن إحداث ارتباك وغرابة وتشوه لطبيعة علاقتها بـالموروث البلاغي لاسيما في صسيغته

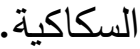

علـى أن ابـن البنـاء فـي تصــوره الكلـي

للبلاغـة، الـذي لا تخفـى صــلته العميقــة بـالفكر اليونـاني: المنطقي والرياضـي، ولا بتراثـه البلاغي العربـي: مصــطلحات ومفــاهيم وشـواهد - كـــان يتطلع، انطلاقاً من الوعي بأزمـة البلاغة العربية وإثـكالياتها، إلـى بنـاء واقـع جديـ للبلاغـة، هو تهو ذاتــــه مســتقبلها، اســتجابة لمتغيـرات لحظتــهـ الحضـارية بأبعادهـا الأيديولوجيـة والثقافيـة؛ بنـاء يشكل تحولاً كيفياً، لا تراكمياً أو كمياً، في النسق البلاغي السـائد، دونمـا نقـد أو قدح. إنــه اتخــاذ لموقف ما من السـائد وسلطته التاريخية، يسعى إلى أن يكون صـياغة بديلـة لسـابقه أو انفصـالاً عنــه، دون أن يـــعي أنــهـ قطيعـة معرفيـة مـع المواضـعات العلميـة المؤسســة للثقافـة العربيـة الإســلامية بعامـة، ودون أن يتخلـى عـن رغبـة الاختلاف معها. جاء هذا الموقف في ظل تراجع الوظيفة الإقناعية الحجاجية للبلاغة في عصره والعصسور المتـأخرة. الأمسر الـذي يؤكـــ ضـرورة انفتاح النسق البلاغي عند ابن البناء، وقابليته للتغير والتنازل عن كليته وتعاليه وثباته، والقبول بالتنوع اللانهائي للخطابات ووظائفها وأشكالها، 
إن البلاغـة في حقيقتهـا هـي فعـل اللغــة وقوتها وتأثيرهـا، هـي تحويـل الخطـاب إلـى فعـل، أي الانتقال بـه من مسكن معزول للغـة منغلقة على هي

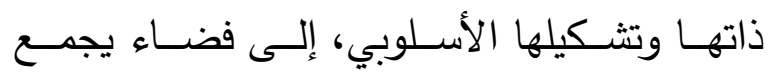
الخطيب والمستمع، المؤلف ومتلقيه، انطلاقاً من حالة فهم، أي إن تحول الخطاب إلى فعل يكون عبـر الفهـم، فهـم الـنص الـذي هـو، كمـا يقـول

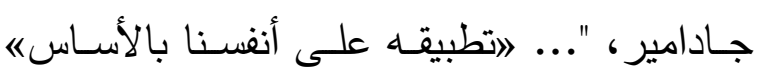

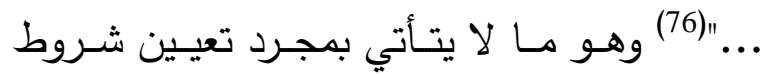
وجوده، بل بالتماهي مع دلالاته ومقاصده وفعاليته

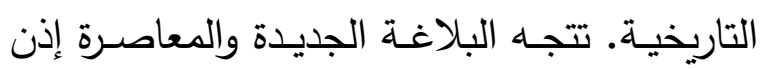
إلى تحليـل النصـوص والخطابـات بـدل إنتاجهـا وحصـرها فـي مقامـات وأسـاليب محـددة وفـق التصور القديم، وهي بهذا تتبع مسار الخطاب في

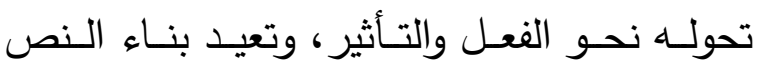
انطلاقـاً مـن فهـم فعاليتـــه اللغويــة ومقصــديته

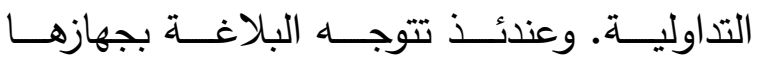
التصـنيفي، لا إلىى إنتاج معرفـة علميـة منضـبطة بالوجوه والصور والتقنيات، أو إلى صياغة نماذج

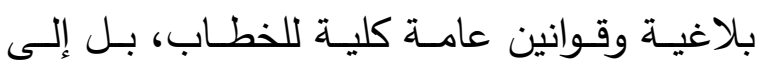

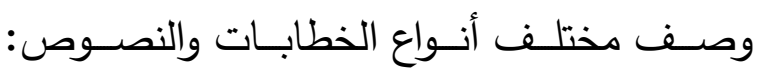
أنسـاقها المعرفيـة، بنياتهـا، أنماطهـا، خصائصـها الجماليـة والأيديولوجيـة، في ارتباطهـا بآثارهـا أو تأثيراتها ووظائفها الممكنـة. فهـي لا تتخلى عن كونها علماً يدعي امتلاكه لقوانينـه المنتجـة لنوع من المعرفة، وأن ما يصل إليه عبر هذه القوانين والإجـراءات هـو حقيقة محتملـة ومتغيرة؛ الأمـر

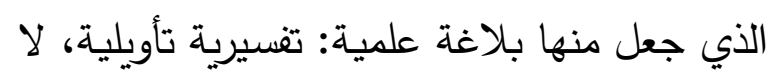
تنفصل عن تاريخية النصـوص وسـياقاتها، وعن
العربيـة، وعدم اختزالهـا في المحسـنات وصسور الأسـلوب، وبمعزل عن تأثيراتها ووظائفها مسن ونـ إقناع وإمتاع وتأثير • فما يسوِغ قيام بلاغة عامـة

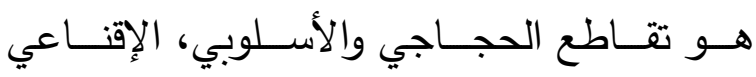
والتخييلي، التداولي والثعري. ولعل هذا ما جعل البلاغة المعاصرة، في نوع من استعادة الماضس، تأخـذ مسـارات متعـددة مـا بـين: بلاغــة شـعرية كـية تخيليية، وبلاغة حجاجية وخطابية؛ ودفع بها إلى أن تتــول مـن الانشـغال بالقواعد والمعـيير إلى الظواهر التي هي "... وليدة تصسور للذات التي تتمثـل العـالم وتصــوغه وفقــا لقوانينهـــا الذاتيــة

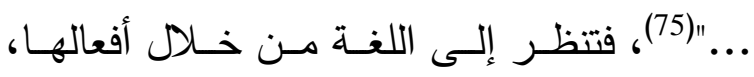
وباعتبــار مقــام الخطــاب؛ وتتجـــه إلــى تحليـلـ النصـوص بمختلف أجناسها، استتاداً إلى امتداد

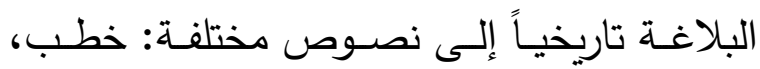

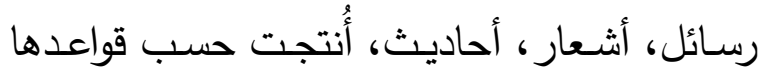

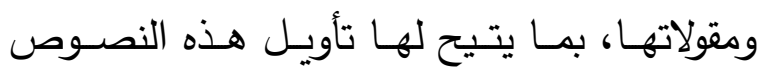
وكثـف مقصــديتها. ومسن خـلال هـــه الوظيفــة الجديدة تعيد البلاغة بناء نفسها، وتضـمن بقاءها حيـة، لـيس فقطط باسـتمرار تلـك النصـوص التي ارتبطــت بهـا تاريخيـاً، مـع تعـددها، بـلـ أيضــاً بارتباطها بالخطاب، كل خطاب، بوصفه أثراً، أو فعـلاً أو فعاليـة. البلاغـة إذن هي فعل اللغـة في بـ في الخطاب وبالخطاب، وهي بذلك تقيم ترابطاً بين

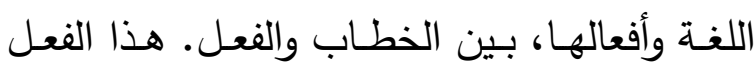
البلاغي أو الوظيفة البلاغية للخطاب لا تقف عند

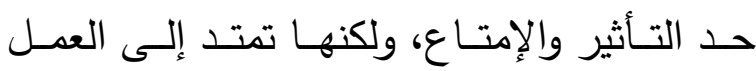
بالخطاب: بتغيير اعتقادات وتشكيل آراء واتخـاذ مواقف، مروراً بتحقق درجات من الفهح والمعرفة. 
والتاريخية، في الوقت الذي ينبغي فيه التعامل مع التــراث بموضـــوعية وعقلانيــة، وفــي إطــــار خصوصـيته التاريخيـة، انطلاقـاً مـن موقف نقدي إزاءه، وبمنهجية علمية حديثة، في ضوء متطلبات العصر وإشكالياته.، بما يحقق نوعاً من الوحدة أو الاستمرارية التي تشكل، عبر مراحل متصـلة أو انقطاعات، وعي أفراد الجماعة وهويتهم. "... إنها تنظم التاريخ بصـورة تجعل من المستحيل عليهم التطلع، حتى على صعيد الحلم، إلى عودة ما قبل ليحل محل مـا بعد؛ ولذلك تجدهم يتجهون إلى المستقبل يواجهونـه ويسائلونه، بل ويسابقونه دون أن يتتكــروا لماضــيهح، أو يجعلــوا منــهـ صــورة لمسـتقبلهم ..."(79) فقـط يحتفظـون بمـا يمكـن أن

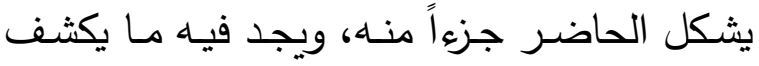
آفاق المستقبل، أي ما يمكن منه أن يكون حاضراً فيهم ومعهم، معاصراً لهم، يؤكد وجودهم، ويشكل هويتهم. وفي ذلك إعادة تأسيس للماضي/ التراث في وعينـا، مـا نحويـه بداخلنا من هذا التراث بعد مراجعته ونقده بعقلانيـة؛ وتوفيرٌ لشـروط وجودنـا ومشـاركتنا في عـالم معاصـر • إنـا إعـادة كتابـة تاريخنا الثقافي، وإعادة ترتيب العلاقة بين أجزائهـ مـن جهـة، وبينــهـه وبـين اهتماماتــــا المعاصــرة وتطلعاتتا المستقبلية من جهة أخرى، وبين التاريخ الثقـافي العـالمي مـن جهـة ثالثـة، والعمـل بالتـالي على تنزيـل الثقافـة العربيـة في التـاريخ الثقــافي العـالمي: ماضـيه وحاضــره، وقـد قمنــا بنقـده هـو الآخر ، من خلال فهم مساراته وتحولاته. لا مفـر في الحقيقـة مـن التسـليم بالمفارقـة التاريخية والمنهجية بين البلاغـة العربية والبلاغـة
أيــيولوجيا مؤلفيهـا، وعــن اسـتجابات متلقيهــا ومؤوليها، فتنهض على الاحتمـالات والممكنـات القرائيـة، لا علـى التمـثلات النمطيــة والبنــاءات الثابتة؛ ممـا عمَّق بالتالي من مباينتها المنهجية، إلى جانب المفارقة التاريخية، مع البلاغة القديمـة على الرغم من استعادتها لكثير من مفاهيمها.(77) كانــت المفارقـة التاريخيـة والمنهجيــة بـين البلاغــة المعاصـرة والبلاغــة القديمـة والكلاسـيكية بتصــورها المعيـاري المــرتبط بالكليـات العامــة والأشكال المجردة، والذي يقف دون مقاربـة ما هو خاص وفردي ونوعي في الخطاب، ودون حداثـة الأشكال التعبيريـة في علاقاتها الجدلية مع الواقع المعاصر ؛ كانـت هذه المفارقة وراء الـدعوة إلى اسـتحالة تجـاوز الاختلافـات، وإمكانيـة إحيـاء البلاغـة القديمـة وتجديــها، أو توسـيع مجالهـا وإنفتاحه، وإحداث تغيير جذري في منهجيتها، حتـى تسـتوعب الخطابـات والأثـكال التعبيريــة بتعـددها وتــوع أجناسـها، ووظائفهـا، وارتباطهـا بمتغيرات الواقع. فالبلاغة القديمة موضوع تاريخي له نسقه الأيديولوجي والجمالي الخاص، وهو أشبه مـا يكون "»... بنظريـة للخطـاب مـا قبـل علميـة، متأثرة بالسياق الثقافي الذي تطورت ضمنهه."(78) فـلا مجـال إذن لاستعادته وإحيائـهـ واسـتكماله. إذ تـأتي هـذه المحاولـة ضــ حركـة التـاريخ وتطـور الفكر ومظـاهر الحياة وتحول الأنسـاق المعرفيـة، وتسـعى إلـى تحيـين منجـز الماضــي بقضـــاياه ومضـامينه الأيديولوجيـة في الحاضـر والمستقبل. إنها أسيرة تصـور للتراث، يضـفي عليـه القداسـة والإطـلاق واللازمنيـة، وينـزع عنـهـ طـابع النسـبية 
بـل هي تحول جذري أو ثوري. فالبديل بمثابـة

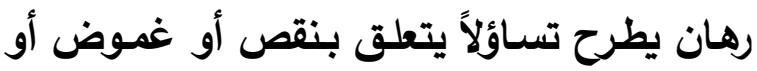
تردد إزاء موضوعه، وهو، طالما لا يحمل انحيازاً أو أيديولوجيا وهمية متعالية، يكتسب مشروعيته من مصدره التاريخي الذي يتخذ منه طريقاً نحو المستقبل، متجاوزاً - وفق منطق سيرورة المعرفة

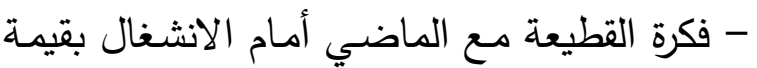

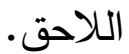

لا يمكن إذن إعادة قراءة البلاغة العربية وكـل بلاغــة قديمـة - وتوظيـف منجزهـا، وفـق إنق منطلقات علمية حديثة شديدة التتوع، في غياب أو انفصال عن حتمية بناء بلاغات جديدة أو بدائل

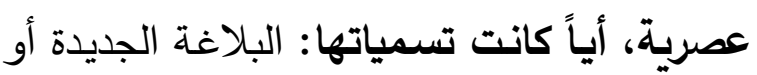
الحديثة أو المعاصرة، بلاغة الخطاب، الأسلوبيات ... إلخ. وهو ما يظهر في التداخل بين المسارين

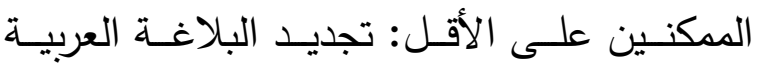

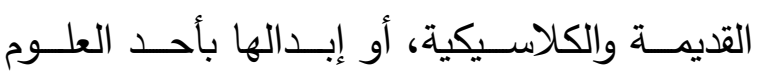

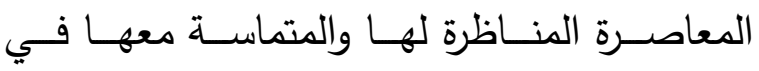
انثـغالها بالخطابـات في كليتهـا وفي تأثيراتهـا

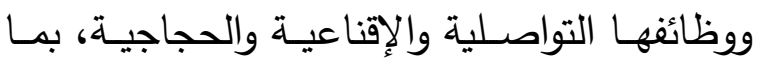
يضــهـ هـا المسـار مـن اقتراح بلاغـات نوعيـة

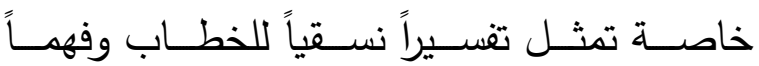
لخصوصياته، وفق مبادئ خاصة: نوعية ونصية. وبعبارة أخرى: إن الاحتفاظ بالبلاغة بوصفها نسقاً تتظيمياً للخطاب قوامه الطابع التأثيري والتواصلي، ومن ثم مظهراً دالاً للسنن الأيديولوجي أو الثقافي

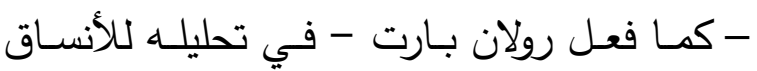
الخطابية المتتوعة: الموضة، الصورة الفوتوغرافية،

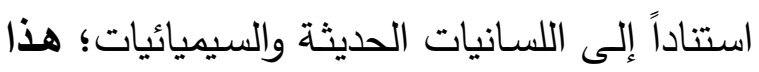

الغربيـة المعاصـرة، والتـي لا تعنـي بالضــرورة الانقطاع عن التراث البلاغي ورفضها، حتى وإن بات علمياً عدم إمكانية ابتعاثه وتجديده من وجهة التهات نظر حداثية؛ بسبب "... عمق الهوة التي تقصل

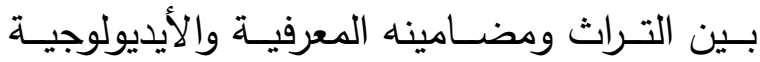
والمعياريـة، وبين الفكر العالمي ومنجزاته العلميـة

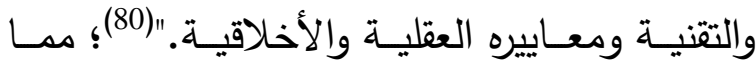
يجعل من مراجعته ونقده، وإعادة ترتيب أجزائه،

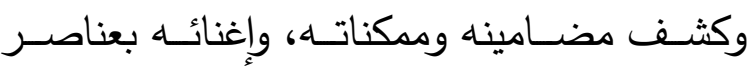
جديدة، وتحريره من تصورات وادعاءات لاتاريخية ولاعقلانيـة رسختها سلطات معرفية متعددة - لا

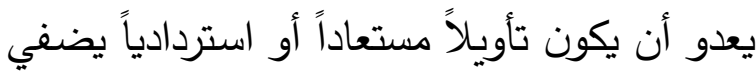
عليه زمنية جديدة، أو يدفع به داخل زمنية كبرى

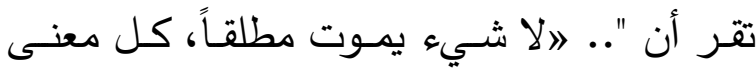

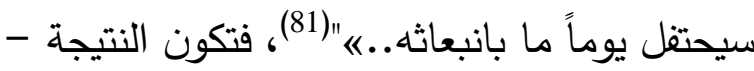
ما يسميه يوري لوتمان - "خلق سلوك مستقبلي

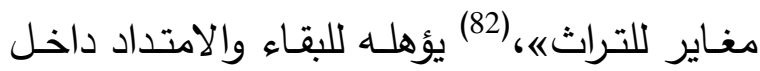
لحظة مـا بعد، لكنه لا يمكن إلا أن يأخذ طريقه

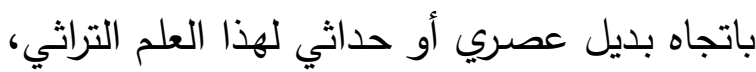

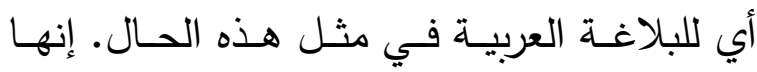
الساعة التي "... لا يجد المرء فيها فائدة للبحث

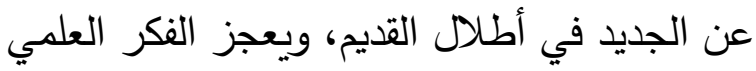
عن التقدم إلا بخلق طرائق طريفة .../ ... [ف] بنية الفكر بنية متحولة منذ كان للمعرفة تاريخ ... إنه يحكم على ماضيه التاريخي بإدانته، وإن بنيته

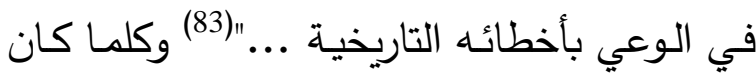

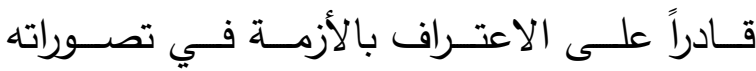

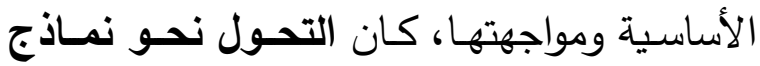
جديدة أو بدائل ليست تحصيلاً كمياً أو تراكمياً، 
الفهم والتلقي والتحليل، قائمـة على النقل والترديد والتــذكر ؛ ورفضـــاً للعــودة إليهــــا أو اســتعادتها بأيديولوجيتها وقيمها وزمنيتها؛ فهو لا يُعد قطيعة إبسـتيمولوجية مـع الماضــ/ التـراث، ولا يسـى إليها، بـل لا يمكنـه ذلك إلا إذا أريد تحول جذزي أو نفي لكل ما هو سائد وموروث من موضوعات وقضـايا وطـرق لإنتـاج المعرفـة؛ تأسيسـاً لوجـود جديــ ينطـوي على رؤيسة مغـايرة ومعرفـة جديـدة ووعي إشكالي بحتمية الاختلاف وتجاوز للحاضر والماضي على السواء. مثل هذا الموقف التحرري الذي اتخذه المجتمـع الغربي مـع صـدمة الحداثـة الأولى منذ ما يزيد عن مائتي عام، والتي كانت تحدياً لما استقر من فرضيات ومسلمات ووقائع، ارتــبط بتفكيـك بنـى المجتمــع وتبـــلها ثقافيــاً واجتماعياً وسياسياً وتقنياً؛ هذا الموقف التحرري لا

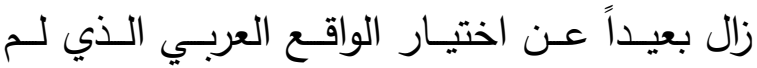
يسـتنبت الحداثــة، واكتفــي مســتهلكاً بمظهرهـــا

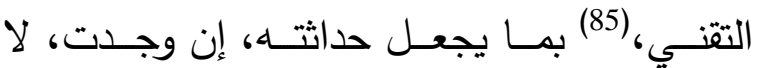
تتــافى تمامـاً مـع هويــة الـذات العربيـة بتراثهـا وثقافتهـا، فـالوعي العربـي المعاصــر مســكون بـالتراث، بالتقافـة العربيـة الإسـلامية، لا بوصـفها بقايـا أو تاريخـاً، بـل مقومــاً مـن مقومـات الـذات العربية، حياً وحاضراً في الوعي. ومن ثم فالحداثة العربيـة مدفوعـة إلىى إعـادة النظـر في المـوروث والقائم، على أساس من وعي تاريخي متغير بواقع متحـول، وعلى أسـاس حوار مـع حداثات الأمس لــ بتتوعاتها وتعارضاتها: في الثقافة العربية والغربية؛ لتغدو انشـفالاً حقيقيـاً بالحاضـر، حاضـر الـذات المختلف والمغاير، عبر كتابة متجددة لتاريخها
التنـاول يخرجهـا عـن كونهـا بلاغـة بـالمعنى المتعـارف عليـه، أو يجعـل منهـا بلاغـة أخـرى ليست بمنـأى عن الالتبـاس بغيرهـا مـن العلـوم ومناهج التحليل، تماماً كما أن مجرد قراءة بنيوية، أو جديدة، للبلاغـة القديمة أو الكلاسيكية لا يبرر وصفها بالحداثة، إلا بإعادة تأسيس - كما يصرح بارت نفسه بثأن الموقفين في قوله: "إن البلاغـة الكلاســيكية يجــب أن يُعـــاد التفكيــر فيهــــا بمصطلحات بنيويـة ... وربمـا يصير من الممكن تأسـيس بلاغــة عامـة أو لسـانية لـدوال الإيحـاء connotation صــالحة للصــوت المتمفصـل، للصسورة، للإيمـاء ... إلـخ"(84) دون أن يعني هـذا بالطبع أن إدخال أو استعمال مصطلحات بنيويـة، أو مفــاهيم جديــدة، فـي قـراءة البلاغــة القديمــة والكلاسيكية - يفضسي إلى بلاغة عامة حديثة أو معاصـرة، إذ على العكس من ذلك، إنها قراءات تُبقي على القديم أصسلاً يُستعاد باستمرار، وتؤُمن بأن الجديد في هذه الحال لا يحدث انفصالاً داخل

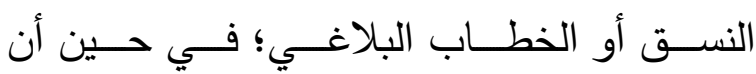
أوصــاف: جديـدة، حديثـة، معاصـرة، حتـى وإن كانـت في مجملهـا تقييـات زمنيـة، فهي ترتبط بتمييزات نوعيـة أو توصـيفات جماليـة أو أدبيـات بلاغية، تنطوي على مفارقة تاريخية عن القديم أو التقليدي، في الوقت الذي تكثف فيـه عن وعي نقدي بوجود تاريخي متغير ومتحول.

\section{ذحو بلديل عصري للبلاغة : علم أسلوب عربي}

إن طرح بديل عصري للبلاغة العربية، كلياً أو جزئياً، ممـثلاً في الأسـلوبيات - أو غيرهـا -

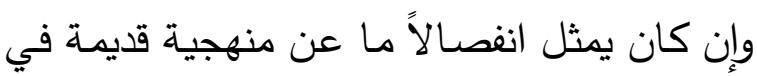


منصرف - في نزعة ارتكاسية إلى مجد الماضسي مشوبة بشوفينية عالية وقناعة بتمامسه واكتمالـه -

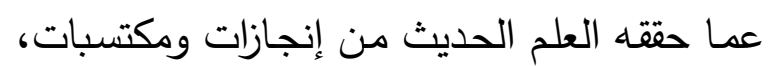
بدعوى انتمائه إلى منابع فكرية وثقافية وأيديولوجية مغايرة، وتعلقه بأسئلة لم يطرحها الوعي العربي لـي

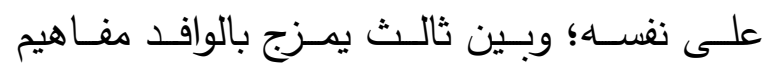
وتصـورات مـن المسوروث، جديرة بإعـادة الاعتبار إليها، والعناية بها، والعمل على إغنائها وتطويرها،

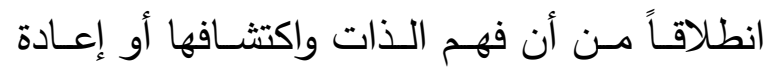
تشكيلها إنما يتم في ضوء معرفة حقيقية بالآخر ؛ وتأكيداً لحضور الثقافة العربية في التاريخ الثقافي لئي العـالمي، الـذي كـان حضـوراً مؤسسـاً، لا مجـرد حضـور وسـيط ومؤقتـ، فقــ كانـت في الحقيقـة إنجازاً لحضارة - كانت ولا زالت تحمل بعضـاً من ون - عالميـة استوعبت غيرهـا من الثقافـات، ومثّلت حلقـة مـن حلقـات الحضـارة الإنسـانية، وكـان لهـا تـراث شــمولي يضــم مفــاهيم وتصــورات دينيــة

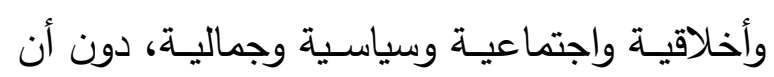
ينفي هذا الحاجة إلى "... نظرة نقدية واعية للتراث تحترم عالميته في آن واحد وخصوصيته التاريخية ... [إذ] لا شـك أن فـي هـذا المجمـوع التراثـي عناصر قابلة للحياة والتطوير ، وأخرى انتهى أمرها

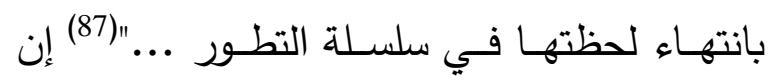
عملية المزج هذه، والتي تختلط حيناً بإحلال بدائل للمـوروث، لا يُراد بها أن تفضسي إلى طمس أحد لهد

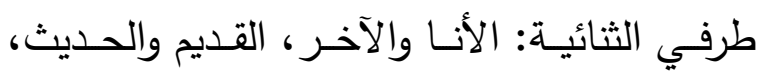
الموروث والوافد، العربي والغربي؛ لصـالح الطرف

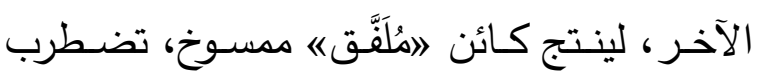
بداخله كل مـن الفكرة التراثية والمفهوم الحـديث،
تعارض الزمنية المتعالية، في الوقت الذي تخرج فيه عن منطق التواصل وسلطته المستبدة، وعن حتمية بقاء الماضي وخطابـه حتى مـع استقبال عناصر جديدة. وفي ذلك انفتاح على ممكنات لا محـدودة، وتبــل للعلاقـة مـع الماضــي والــات والتــــــخ واللغــة، ليغـدو (أي الماضــي وغيـره) موضوعاً للمعرفة والتأويل. في ظل هذه الوضعية لن يكون توجـه النقاد والدارسـين العـرب نحـو المنــاهج الغربيـة بعامـة اعتباطياً، ولا وليد ترف، أو مجرد نقل ومحاكاة، وإنمـا هـو اسـتجابة لمتطلبـات العصـر وحاجاتـه، وأثر للـوعي بـزوال قيم الماضـي أو تجاوزهـا في الواقع المعاصر الآخِذ بمبادئ الحريـة والاختلاف. لقد وجدوا في الأسـلوبيات، وغيرهـا مـن المنـاهج الحديثة، سبيلاً إلى إحداث نقلة نوعية في مجال النقد ومقاربـة النصـوص الأدبيـة، ضـــن مشـروع لتحديث الفكر والعقل العربي، لمـا يفرضــه الواقـع المعاصر من تساؤلات وتحديات وإشكاليات. وهم في ذلك مـا بين مشـايع للوافد المستحدث دونمـا

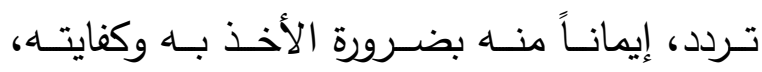
لاعتماده تحليلًً علمياً موضوعياً لله جهازه الفكري والمصـطلحي الضـخم وإجراءاتـه المنهجيـة الدقيقـة والمنضبطة. فالتوجه إلى المناهج الغربية في هذه الحالة بمثابـة خيـار ضـروري أو حتمـي استوجبه الثـعور "... بعمق الهوة التي تفصل بين التراث ومضامينه المعرفية والأيديولوجية والمعيارية، وبين الفكر العـالمي ومنجزاتـه العلميـة والتقنيـة ومعاييره

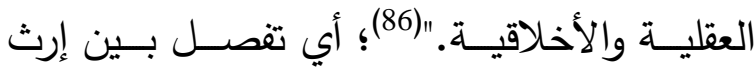
الماضــي وحداثـة العصــر ؛ وبـين فريـق آخـر 
أسـلوب عربـي يكـون اسـتجابة لمتغيـرات الواقـع المعاصر ، كما كانت البلاغة العربية القديمة تلبية لمطالـب وحاجـات أيديولوجيـة، واسـتجابة لشـرط جمالي وحضـاري وتاريخي، اصطبغت فيه بثقافة عصـرها الفلسفية والمنطقيـة. وإلى أن ينشـأ علم أسـلوب عربـي، أو بلاغـة عربيـة معاصـرة، أو نظريـات نقديـة عربيـة ... إلـخ، في إطـار نظريـة إبسـتيمولوجية عربيــة معاصــرة، تصــوغها ذات تاريخيـة، تعـي حاضـرها بإشــكالياته ومتطلباتهـ، وتتفتح على ثقافة العصـر، وتتعـايش مـع الآخر المختلف، بقدر ما تمتلك فهماً موضوعياً ومعقولاً لتراثها؛ إلى أن ينشأ ذلك ويتحقق، لا يبقى سوى اتطلع أو الأخذ ببدائل عصريـة، ليست تطويراً أو تجاوزاً لما في الماضسي، ومن ثم لا قطيعة معه ولا إقامسة فيـه بداهـة. (89) إنها بـدائل يُرجى منهـا حلولّ علميـة لأزمـة النقد العربي في افتقاره إلى أسس تقيـيم موضـوعي وشـامل، لـم يعد الموروث قادراً على إنجازه، ف"... التحليل البلاغي [القديم] عـاجز عـن إعطـاء تفسـير ذي دلالــة للأعمـال

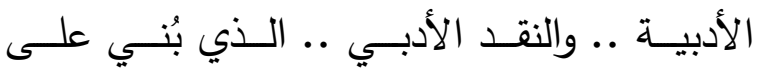
تقسـيمات عريضــة مبهمـة، واعتمـــ على أحكـام انطباعيـة سـريعة، عـاجز عـن إسـباغ شـيء مـن الموضوعية على مناهج البحث الأدبي ..."(90) وكان لاندفاع الدارسين العرب بعامـة نحو الأسلوبيات ما يبرره من اعتمادها إجراءات علمية موضـوعية فـي وصـف الظـواهر والبنـى اللغويـة وتحليلهـا، بعيـداً عـن الانطباعيـة والذاتيـة، وعـن الاعتبارات والسياقات الخارجية، مستتدة في ذلك إلى شبكة مـن المفـاهيم والمصـطلحات والمبادئ
تلفهما عتمـة متكافئة - شـأن كثير من الدراسـات العربية التي أخذت بالمنـاهج الغربيـة دون التمكن من هذه المناهج وتمثلها، والإلمام بأسسها الفلسفية

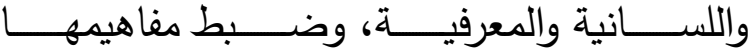
ومصــطلحاتها، مدـا أدى إلـى تثـويها والإخفـاق الواضح في تطبيقها، ومن ثم كان ضعف مستوى تلـك الدراسـات وقلـة فائـدتها ومحدوديـة نتائجهـا، على نحو مـا يتجلى في الفجوة الكبيرة بين مـا تقدمـهـ مـن طـرح نظـري ومـا تتجـزه مـن تحليـل للأعمال الأدبية وخصائصها الجمالية والأسلوبية، وما يكتنفها من غموض وتعقيد وتعسف؛ هذا إلى جانـب قصـورها عـن متابعـة المـنهج أو النظريــة الغربية في تطوراتها وتحولاتها، والاكتفاء بجانب منها تراه أكثر استقراراً وأقل إثارة للجدل، وأخف مؤونـة، من غير التفات إلى مسيرتها ومـا يُستجد فيهـا مـن تسـاؤلات وإشـكاليات هـي مـن صــميم حقيقتها، ومن ذلك وقوفها بالدرس الأسلوبي عند

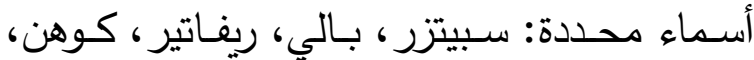
دون الإلمسام بمقتضـيات عملهم، وتطـور أدواتهم، ورؤيــتهم الثـــاملة للظــــاهر المدروســـة، ودون الانتهاء في كثير من الأحيان إلى بعض غاياته؛؛ الأمـر الذي أدى بهذه الدراسـات العربية إلى "... خليط مشوه وشتات مضطرب من الثروح اللغويـة، والملاحظــات الفيلولوجيــة، والبيانــات البلاغيــة المشوبة بظلال المفاهيم الأسلوبية، مع تفاوت في نِسَب الأخذ مـن هذا الاتجـاه أو ذاك، وإذا عملية النقـد قائمــة على إرسـال أحكـام جـائرة خاليـة مـن

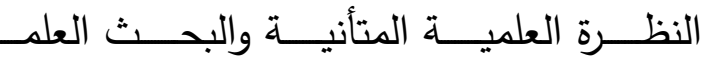
الرصين."(88)، على نحو لا يؤذن بقرب ميلاد علم 
الحاضـر وتطلعـات المسـتقبل، وبضـرورة إعـادة تفسير الماضي في ضوء ثقافة العصر ، سعياً نحو إنجاز ذاتي للهويـة في صيرورتها وفي علاقتها بأخر مغاير؛ في هذا السياق يتطلع اشكري شحم عياده إلى تنزيل علم البلاغة في التراث العربي

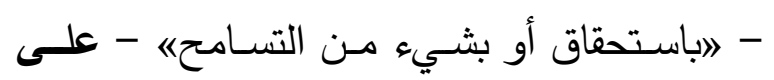

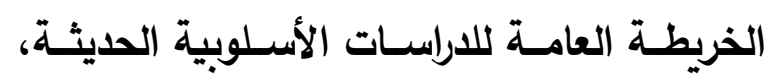
ليس استتاداً إلى مـا بين البلاغـة العربيـة وعلم

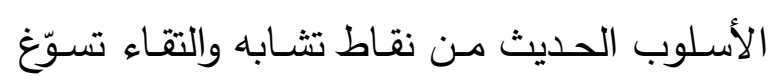
عمليـات تقريـب أو قـران أو تتسـيب، او مــا قـــ

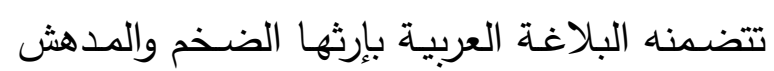
مـن أفكـار يمكـن أن تكــون ســـوابق لمفــاهيم وتصـورات أسـلوبية، إذ بينهمـا اختلافـات جوهريـة عميقـة على مستـوى المـنهج وإجراءاتـه؛(91) وإنمـا تقف وحدة الموضـوع بـين العلمين - أي دراسـة

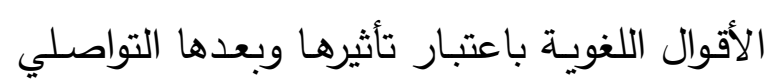
بما هي استعمالات أو تصرفات خاصة في النظام

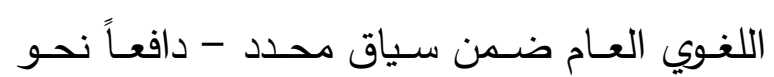
تحليـل شـامل وموضـوعي ودقيق للبلاغـة العربيـة

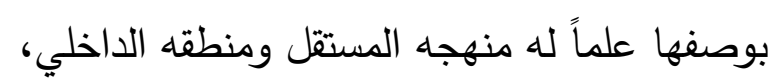

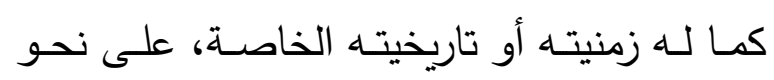

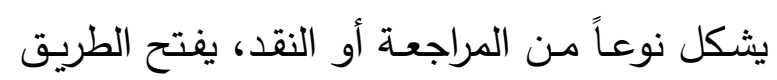
أمام بحث حر لمستقبل البلاغة العربية، وهو مـا يحققـه الانتفـاع بتجربـة علـم الأسـلوب، وبمنـاهج

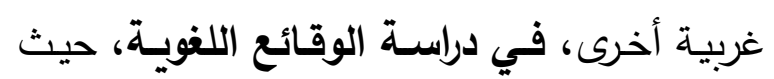
يتجه علم الأسلوب إلى وصف هذه الوقائع وصفاً علمياً موضوعياً، بما هي استعمال للغة لا لا يمليه نظامها العام وما يسمح به أو يتيحه من إمكانات (للعدول)، ولا يقتضـيه تصـور منطقي للمقام؛ أي
المنضبطة إلى حد كبير ، والمستمدة دن اللسانيات بنماذجها الصـارمة؛ فضـلاً عن تقاطع الأسلوبيات واتِ مـع المـوروث البلاغي واللغوي على نحو يسـح بتقبلها وتتاميها خارج منشأها. هذا إلى جانب ما استقر فـي الـوعي النقدي العربـي الحـديث مـن مفـاهيم فيلولوجيـة تبنتها الأسـلوبيات في مراحلها الأولى، أوضـحها علاقـة النص بصـاحبه وبـروح

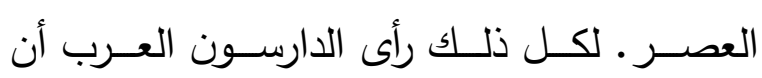
الأسـلوبيات يمكـن أن تســ فراغــاً خلفـه تراجـع البلاغة في مجال تحليل الأقوال اللغوية والأدبية،، وتغطية المجال الذي يقع بين اللسـانيات ودراسـة الأدب، في وقت لا سبيل فيه إلى تجديد البلاغة أو تحديثها لما يقتضيه من إحداث تغييرات جذريـة

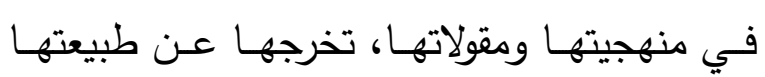
وحدودها. فالبلاغـة نسـق معرفي يتميز بنزوعـهـ

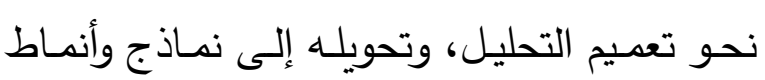
وقواعد وقوانين: كلية وعامـة ومجردة، تغدو قوالب

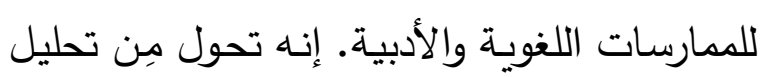
النصوص، أو عَنْه، إلى إنتاجها وفق ما هو مقرر

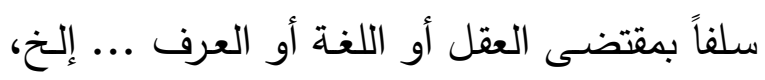
في حين تتجه الأسلوبيات إلى دراسة وقائع التعبير الفرديـة، وتحليـل النصـوص والخطابـات، انطلاقـاً من فهم مغاير لوظيفة اللغة ومستوياتها وعلاقتها

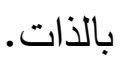

وفـي سـياق طــرح البـدائل، والــني لا

ينفصل عن البحث عن مكان للثقافة العربية بين ثقافات العالم المعاصر، من غير خضوع للوافد أو لئ تجاهل لتفوقه ومركزيته، ومن غير تتكر للماضي/

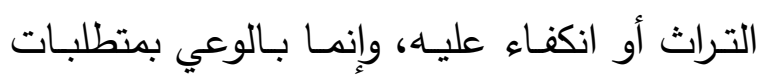


الأدبية، إلى على الأسـلوب، أو إعـادة صسياغتها في هذا العلم الجديد.94) هذا الموقف من جانب شكري عياد، والذي - كان ولا يزال - يشـاركه فيـه كثيرون، قد يبدو طبيعياً باتساقه مـ لحظة تاريخية شهدت اندفاعاً نحو الأخذ بإجراءات ومقاربات وصفية موضوعية ادعى الأسلوبيون إخلاصهم لها وتمسكهم بها. إذ ليس بالإمكان تجريد البلاغة من فلسفتها المتعالية ومحتواهـــا الأيــديولوجي فــي أي عصــر مــن عصـورها، ومـا يـرتبط بـذلك مـن تكـريس لنسـق وجـودي ومعرفي وقيمسي ثابــت ومهـيمن، ومـن إقصـاء للاختلافـات والاحتمـالات والممكنـات مـن الظواهر والخطابات والممارسات الفردية؛ لا يمكن تجريــ البلاغـة مسن نموذجها المعيـاري والكلـي، وتجاوز مباينتها المعرفية للفكر المعاصر، دون السقوط في مفارقة مع جوهر البلاغة وماهيتها، ودون مواجهة الحتمية العلمية التي تقضي بشرعية حدوث علم جديد أو نشـأته عند حدوث قطيعـة منهجية مع سوابقه، واعتماد منهج جديد في تناول الظاهرة نفسها، مما يجعل من الأسلوبية في هذه

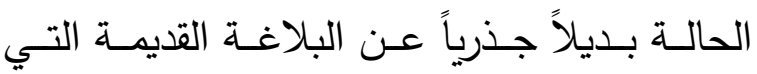
يشترك معها في مـادة البحث، من غير أن تكون

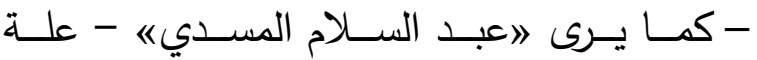
لوجـوده، فمـا أوجده هـو تلك القطيعـة أو الباينـة المنهجية. (95) ويبقى الخيار المطروح هو إعـادة القراءة وفق تصسورات ومفـاهيم ومعـارف حديدة تـدفع إلـى مزيـــ مـن الـوعي النقدي بإشـكاليات البلاغـة العربيـة وفرضـياتها، يحفظ لهـا منجزهـا المشروط بزمنيته وقيمه الأيديولوجية والجمالية،
بما هي استعمال أو تصـرف فردي خاص وحر في اللغة، يحمل آثار فاعله أو متلفظه من مقاصد وتصورات ومشـاعر ، كما يجسد العلاقات النفسية والاجتماعية للمتخاطبين، ويؤدي وظائف ودلالات يستدعي الإحاطة بها تحليل الواقعـة اللغويـة على مسـتويات متعـددة: الإفراديــة والتركيبيـة، الآنيـة

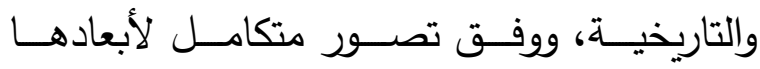
وعناصرها التكوينية والأجناسية، بالاستعانة بعلوم العصر ومعارفهـ. وانطلاقاً من هذا شكَّل البحث عن مستقر للدرس الأسلوبي الحديث في الثقافـة العربيـة جانبـاً كبيراً مـن انشـالات شكري عيـاد، على مسـتوى التـأليف والترجمـة، (92) مستفيداً قي ذلـك ممـا حـدث مـن تطـور للمعرفـة اللسـانية والنقديـة، ومعتمـداً على تصــورات ومفــاهيم في التـراث البلاغـي والنقــدي، تتعلـق بطـرق القـول وأسـاليبه، مـع وعي مفرط بمفارقة علم الأسلوب

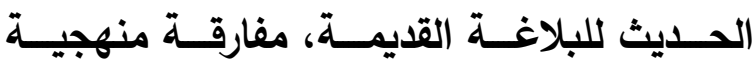
وتاريخيـة تـدعو، لا إلحى بعـث البلاغـة وإحيائهـا وتطويرها، أو حتى الطموح إلى تعايشها مـع علم الأسلوب، بل إلى استبداله بها، وإنزالها ضمنه؛ أو العمل على استعادة بعض من إنجازاتها - ولا ضسير أن تُعتبر هذه الاستعادة تجديداً أو بعثاً في صورة "... امبادئ علم الأسلوب العربيه كما

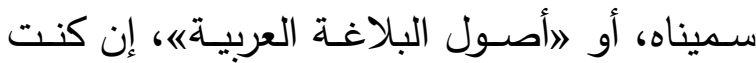
حريصاً على الاسم القديم ..."(93) وهي دعوة تدفع بالبلاغة العربية إلى المصير ذاته الذي آلت إليه البلاغة، أو لالريطوريقاه، عند اليونان في الغرب - على نحـو مـا يـرى شكري عيـاد - بـالتحول عنها، لقصورها عن إظهار القيم التعبيريـة للآثار 
تجريبـي، وخلــ للأجنـاس التعبيريـة ولمسـتويات تحليـل اللغــة بحسـب تـــوع الخطابـات، واعتمـاد الثاهد والمثال المغرد والمنتقى بما لا يمكن اعتباره

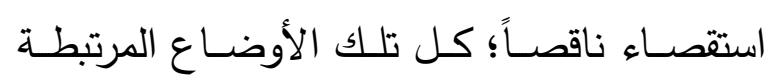
بالبلاغة مما ينافي الروح العلمية الحديثة قد أدت - فيما يرى 》صـلاح فضله - "... - إلى انفصسام

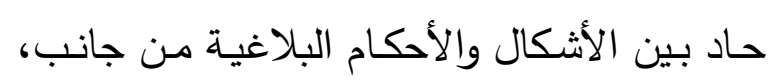
والإبداع الأدبي والثعري من جانب آخر ... بـل .. قد أعاق البلاغة العربية عن بناء جهاز متكامل قـادر علىى اسـتيعاب التحـولات الأدبيـة التاليـة للعصر النموذجي عندهم."(97)، ومن ثم قادر على الإحاطـة باتسـاع تجليـات الظـاهرة الأدبيـة عبـر

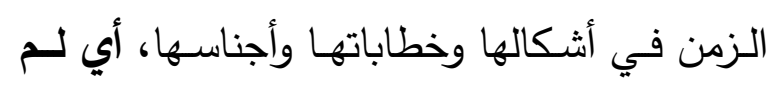

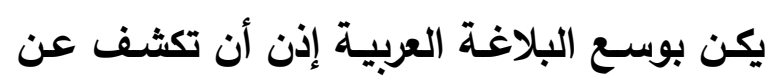
وعي أسلوبي باللغة في مستوييها العام والأدبي، فمقاييسها مغـايرة لتلك التي تعتمدها الأسـلوبيات وغيرها من المنـاهج النقديـة الحديثة. وإن لم يكن مـن المستبعد - فيمـا يقول صـلاح فضـل - مـن الانتفــاع الجزئي بالبلاغــة ضــن مشـروع لإعـادة

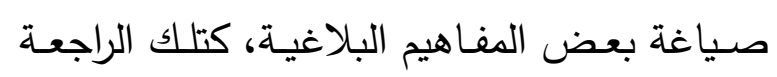
إلىى الصـورة، وإدماجهـا في المنظومـة المنهجيـة

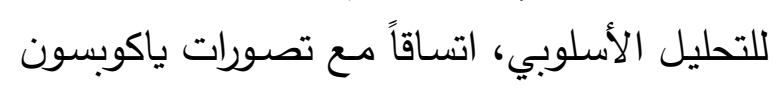
ولوغورن وغيرهما. (98) هذا الموقف، الذي لا يطمسح إلى تطـوير البلاغة القديمة وتحديثها، لا يتردد في الإقرار مـع

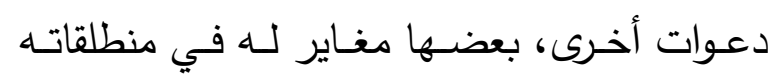

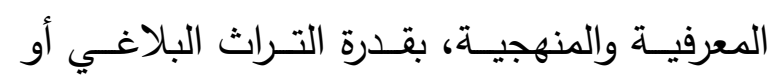

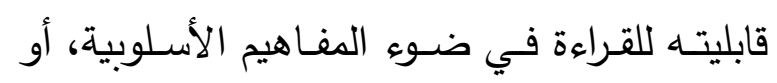
توظيف إجراءاته في التحليل الأسلوبي المعاصر
ومـا يمكن أن يحملـه مسن بقايـا صـالحة تؤهلهـا

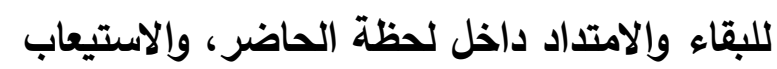
ضمن صياغات أو بدائل عصرية،، دون أن تجعل منها بلاغة حديثة أو معاصرة. فإعادة النظر في كثيـر مـن أوضــاع البلاغـة العربيـة وتصــوراتها وتصنيفاتها وفق المنهج العلمي الحديث، وتقويمها تقويمـاً لسـانياً، في ظل حركـة نشطة في مجـال

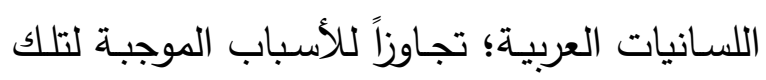
المباينة المعرفية - فيما يقترح اسعد مصلوحهي -

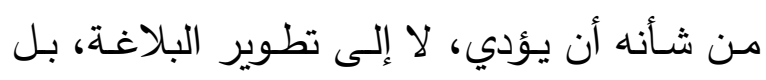
إلى الانتفـاع بها وتوطيفها في البحث اللسـاني الأسـلوبي، على مستوى الإجـراءات البحثية دون الأبعاد الإبستيمولوجية. وفي سبيل ذلك ينطلق من

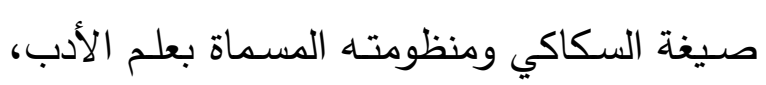
مـع تكميلهـا، واعتمـاد فكـرة المسـتويات التحليليـة أساساً للتصنيف؛ ليقوم بإدماج تلك المنظومة في

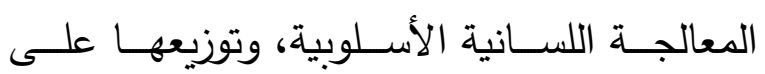
مجالات تستوعب فنون البلاغة. (96) وقد تبدو بالنسـبة لآخرين عمليـة الانتفـاع والربط بين علم الأسلوب الحديث والبلاغة العربية القديمـة، أو التأصسيل لعلم أسلوب عربـي، ضـرباً مـن التعسـف، حيــث تمثـل كـل مـن البلاغــة والأســلوبيات نسـقاً معرفيــاً مختلفــاً لـهـ خلفيتــهـ

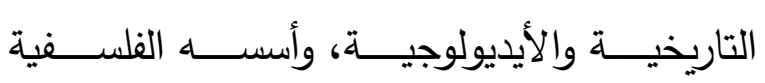
والمنهجية، ولا سبيل لردم الهوة الزمنية والمعرفية والمنهجيـة بينهمـا، والدفع بالبلاغـة ضـمن أصسول

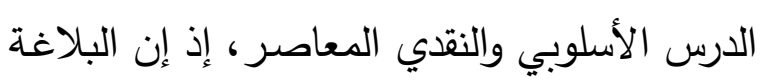
بمـا تتتهجــه مـن نظـرة معياريـة: متعاليـة وغيـر تاريخيـة، وتصـور منطقي عقلي: صـوري وغيـر 
مـن الأفكـار المهمــة التـي تجعـل لعملهـم وزنـاً ملحوظـاً .. بالنسـبة للدراسـات الأسـلوبية الحديثـة (102)" ...

هذه المقترحسات أو المقاربـات بـين البلاغـة العربية والأسلوبيات الحديثة يمكن أن تجد لها في بعض المواقف مـن البلاغـة الغربيـة مـا يـدعمها

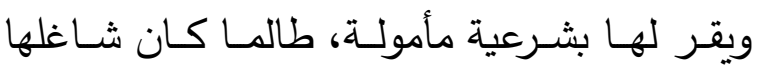

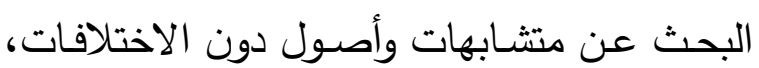
ودون اعتبـار لمسـيرة الفكـر البلاغـي والأسـلوبي والنقدي في الغرب، فلم يكن القصد في أكثر هذه المواقـف شـهرة، عنــــ جماعـة مـو مـثلاً، إحيـاء البلاغة القديمة أو ترميمها، بل إعادة بنائها على أسسس علميـة حتى تُسـتخل في الأسـلوبيات أو تأخذ صـورة بلاغـة عامسة معاصـرة نصسيبها مسن البلاغــة القديمــة هــو التســمية وعـدد مــن المصطلحات التي أطلقت على أنواع من الصـور البلاغيـة، بينمـا هـي تتجاوزهـا إلـى البحـث في معطيـات الاسـتعمالات البلاغيـة للغـة وتفسـيرها وتحليلها وفق منهج علمي يستتد إلى اللسـانيات

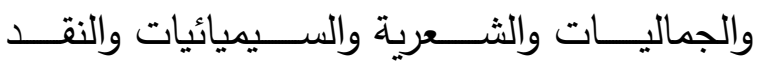
الأدبي. (103) لقد بدا إذن لشكري عياد - وغيره - أنه لم يعد بالإمكان، في ظل معطيات التطور العلمي والمعرفـي والحضــاري، إحيـاء البلاغـة القديمــة، وتفادي تحولها إلى حقل معرفي حديث له منهجيته

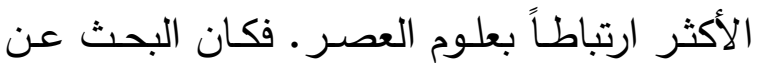
بـدائل مـن بـين الحقول والمعـارف المتقاطعـة مـع البلاغـة، وجاءت الأسلوبيات أوضـح هذه البدائل أو المقترحات. غير أن الأسلوبيات وجدت نفسها،
للنصـوص الأدبيـة، وفي التحليـل النقدي بعامـة، على نحو مـا حدث في الغرب، حيث أعاد النقد الحديث تحليل نصوص البلاغة القديمة والوسيطة وتقديمها والإفـادة منهـا، بمـا أكسبه - كمـا يشير ״أحمد درويش《 - شرعية وجذوراً، خلافـاً لواقع النقد العربي الحديث الذي تضعف صلته بالتراث البلاغي؛ ومـن ثم يفتقد إلى نظريـة اذات مذاق

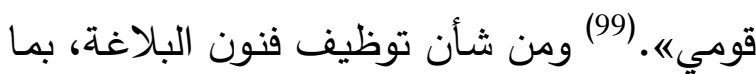
هـي وسـائل تعبيريــة، ضـــن منظومــة التحليـل الأسلوبي للنص في كليته ومستوياته المتعددة أن تحيـل، بـرأي بعـض النقــاد، الاخـتلاف بـين البلاغـة والأسـلوبية إلـى ائـتلاف حيـث يتــآزر العلمان في تحليل النصوص والكثف عن قيمها الجمالية والفكرية. (100) بل يمكن أن يصير العلمان إلى تكامل يتجـاه بالبلاغـة نحو مهمـة جديدة هي تحليل النص والكثف عن نظامـه، فالبلاغـة تبدو للـــدارس المنصــف - وفـق عبــارة المحمد عبــد المطلبه - صـالحة للأسلبة الحديثة، وما بينهما من تعـارض فهو مؤقت؛ ومـن ثم يمكن لإعـادة النظر في الأدوات البلاغية بالتوظيف، والتطوير والتعديل، إلى جانب استحداث أدوات وافدة بعد تطويعها لروح البلاغة العربية؛ يمكن أن يفيد "... إفـادة بالغــة في تقـديم نظـام ذي أصــول عربيـة، صـالح للتعامـل مــع الخطــاب الأدبـي العربـي

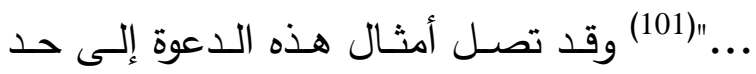
القيام بعملية اختبار المفاهيم البلاغية، ووضـعها إزاء مـا يقابلها في الدراسات الأسلوبية، أو إنزالها محلهــا مـن هـذه الدراسـات، تأكيـداً علــى أن أن البلاغيين العرب "... وصلوا بجهودهم إلى طائفة 
نظريـة عامـة للخطـاب، أي ضــن تصـور موسـع

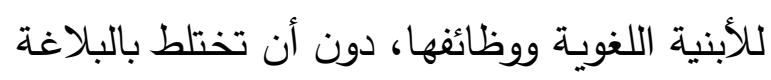

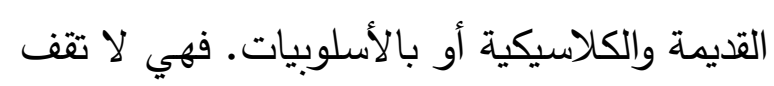
عند دراسـة الاستخدام الفردي للغـة كالأسـلوبيات، بل تتجاوز التحليلات الأسلوبية إلى رصد أشكال

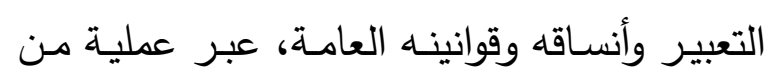
التعدـيم العلمـي النسـبـي المبنـي علـى الخبـرة بالوقائع. (106) وهو ما قد يثير إلى أن الأسلوبيات لم تتمكن من أن تحل محل البلاغة، أو لـم تفلح في أن تتحول إلى بـيل مقنع أو وربـث حقيقي للبلاغة، إذ لم تسعفها مبادئها وتصوراتها اللسانية المرتبطة بالبنية الشكلية للجملة والنص، وبالمفهوم الفردي للأسلوب، في الانفتاح على مختلف أنواع

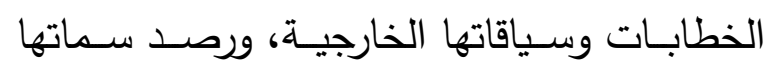

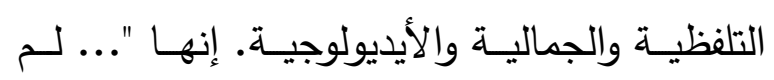

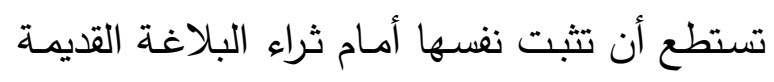

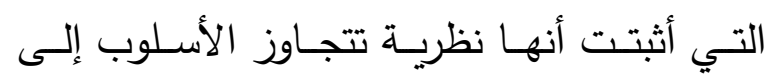

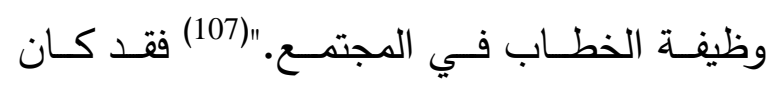

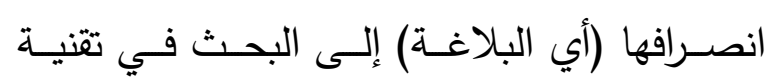
الخطاب: مقاصده وحججه، بنائه وترتيبه؛ وكذلك الك تصنيفها لأساليبه، هو في حقيقته اعتراف بسلطة اللغـة وسيادتها في المجال الاجتمـاعي. ولم تكن لأن

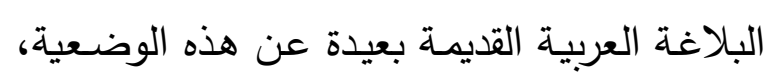
فقد كانت ملكة تحقق لمن يمتلكها امتيازاً وتفوقاً وسلطة وهيمنة على الأخرين، بما يرتبط بذلك من فن فرض إرادة وإخضـاع وإقناع، وتكريس لقيم فكريـة

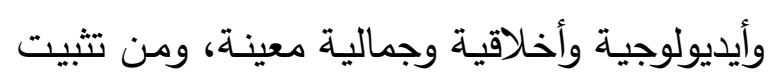

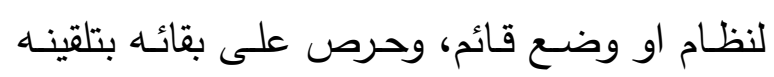

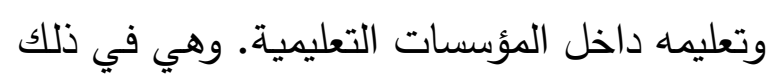

مرة أخرى بمقتضى التقدم العلمي، وبسبب ما ؤجهـ

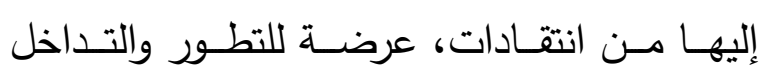
والانفتـاح على اختصاصـات أخـرى كالتـداوليات والسـيميائيات، وعلى مواجهـة إشـكاليات تتجـاوز

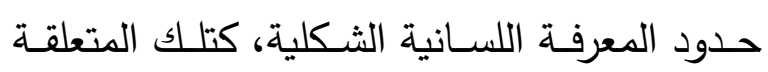
بالتلفظ، مقام التواصل، المقاصد، القيم، استجابة المتلقي؛ الأمر الذي دفع بالأسلوبيات إلى التخلي

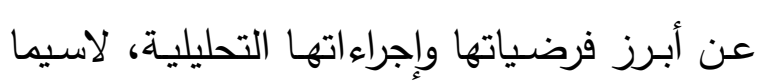
تلك المتعلقة بعدم كفايـة الوصف الشكلي للأبنية

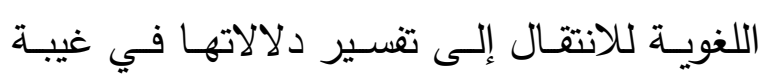

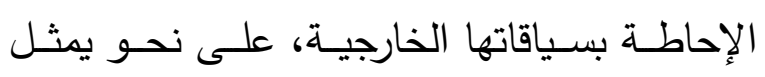
إعلانـاً عـن نهايـة الأسـلوبية، أو بدايـة أسـلوبية جديدة (104) تتخلى عن التركيز أو الانغلاق على الشكل اللغوي ووظيفته الاستطيقية؛ لتدرس مـا تحثثه العلامسة الاستطيقية من تحول في الفهم الكلي للعالم، من خـلال اللعب بالعلامـة وإدماجها مـع تجـارب المُدرِكِ/ المتلقي في الحيـاة والفن؛ فذلك - وفقاً لـهيلان يانكوفتشه - هو الهدف الصـحيح للأسلوب أو مـا يجب أن يكون، والذي هوني يقضي بعلم الأسلوب أن يتجاوز حدوده.(105) وقد ساعد على تكريس مثل هذه القناعة ما حدث من عمليات متواصلة لاستعادة البلاغة القديمة ضمن ملن صياغات وآفاق حديثة للتحليل العلمي للخطاب، شكلت ما أصبح يسمى بالبلاغة الجديدة أو العامة

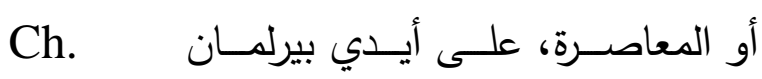
Perelman الأسلوبيات وعدداً من مقاربات الخطاب التداولي والإقناعي والإشهاري والتخييلي، في سياق تحولها عن وظيفة إنتاج النصوص إلى تحليلها في إطار 
بديلاً عنها أو عن البلاغة العربية القديمة. ويختار شكري عياد لتحليله أو مراجعته أحد

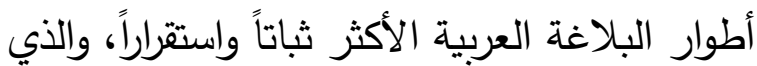
يستوعب ما مر بها من تحولات تاريخية سابقة، كما يتضمن بداخله في الوقت نفسه، شأنه شأن أي طور أو حالـة من حـالات الثـيء (المتعاقبة

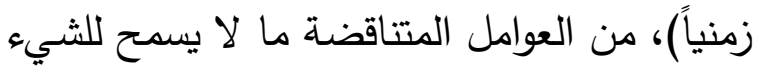
أو الظاهرة أو العلم بالاستقرار، وإن كان هو ذاته سر بقائه حياً. هذا الطور هو بلاغـة السكاكي الطاني

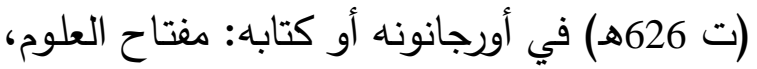
وفي تلخيص القزوينـي (ت بالإضـافة إلسى شـروح التلخـيص، حيـث يرصــ شكري عياد بعضـاً من مظاهر التتاقض الداخلي

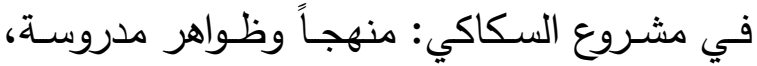
تتعلـق بـالجمع بـين ثنائيـات متتاقضــة: الإفـادة والتحسين، الأصل النحوي والاعتبارات البلاغية. فبلاغـة السكاكي وشراحه التي تفتقر إلى لفى

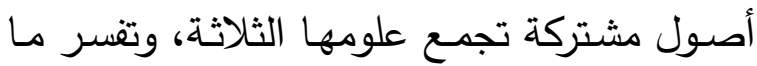
بينها من علاقات بوصفها علوماً متساوقة؛ هذه البلاغة - وفقاً لثكري عياد - جاءت موزعة بين الإفادة أو الاحتراز عن الخطأ (في تأدية المعنى

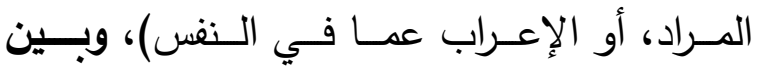
التحسين، أو الحسن والقبول، أو الوجوه المسماة

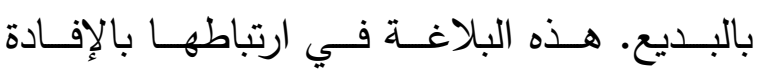

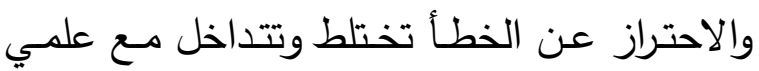

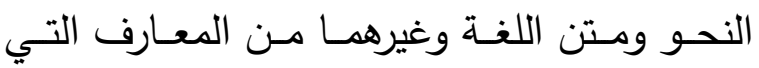

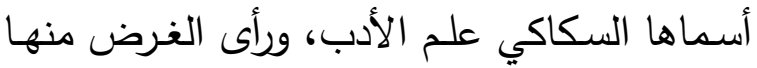

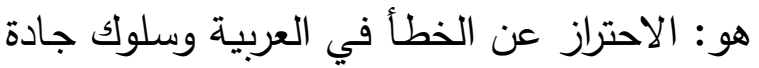
الصواب فيها، مما حال - فيما يرى شكري عياد
كانت تنهض على تصور فلسفي للوجود وموقع الذات منه؛ كما كانت تعكس تصوراً خاصاً للغة ولوظيفتها، ولوظيفة البلاغة ذاتها في خدمة النص القرآني، انطلاقاً من لحظة القوم التاريخية، ونسق

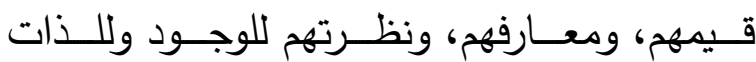

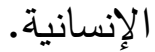

لا يمكـن إذن إغفــال واقــع الأســلوبيات ومستقبلها عند النظر إلى قراءة شكري عياد وغيره - للبلاغة العربية في علاقتها بعلم الأسلوب الحديث، في ظل وعي بما يطرأ على الأسلوبيات من تطور يرافقه توسيع لمجال عملها وفرضياتها،

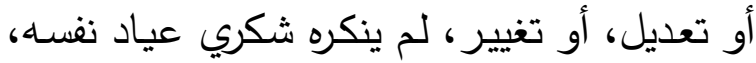
من خلال إثارته إلى دفع السيميوطيقا والبراجماتية

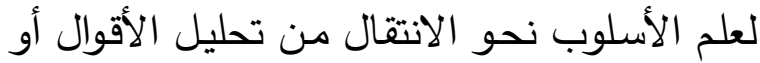

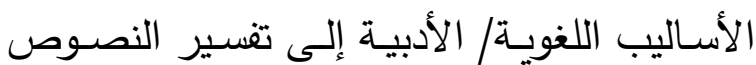
الأدبية على أسس علمية دقيقة مستمدة من نظريـة

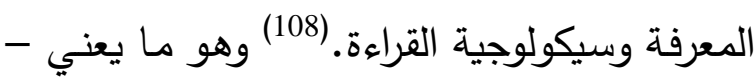
بالنسبة لآخرين - انضواء الأسلوبيات ضمن علوم

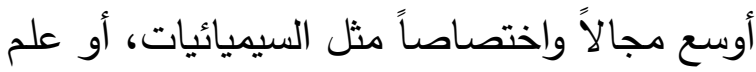

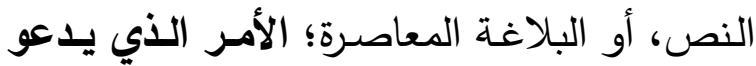

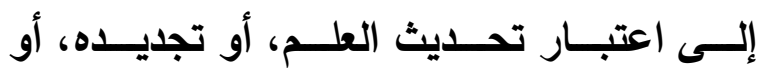
عصرنته، أو توسيع مجالـه - هو بمثابـة بديل (عصري) له يمكن أن ينهض علماً قائماً بذاته لا لابه بلهايل

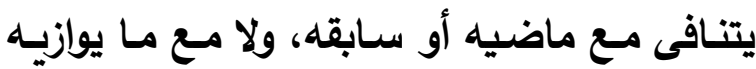
في ثقافة أخرى، بقدر ما يمثل استجابة لقانون

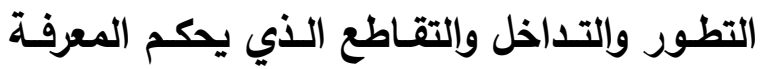
الإنسانية؛ وبناء على هذا يمكن التطلع إلى علم أسلوب عربي حديث يأتي ضمن بلاغـة عربيـة

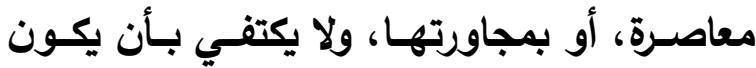




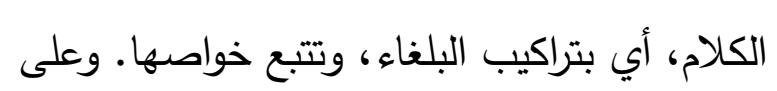

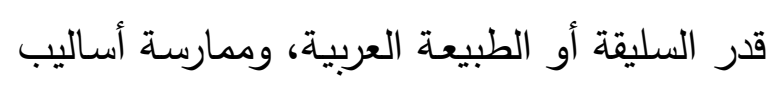

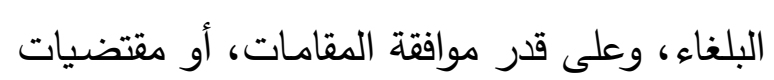

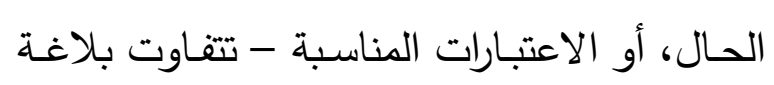

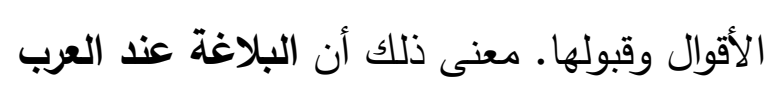
. في تحققها وفى مراتبها وفي حسنها وقبولها . مرتبطة بدرجة تطابق كلام المتكلم مـع الاعتبار

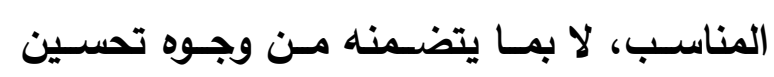
وصور . يقول السكاكي: "... وارتفاع شأن الكلام

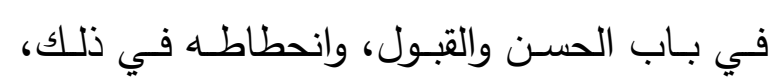

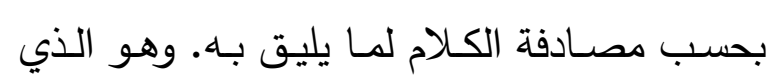

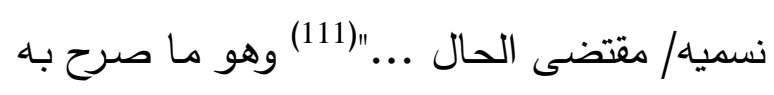
من قبلُ عبد القاهر الجرجاني بقوله: ".... المزيـة والحسن يكون فى إثبات ما يراد أن يوصف بـانه

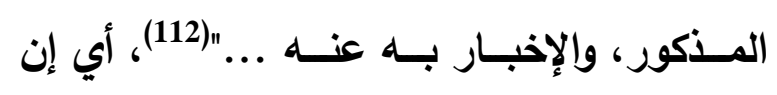

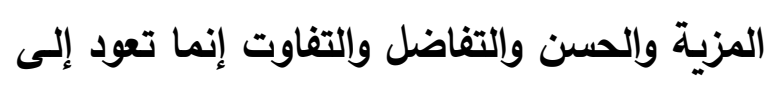
مراد المتكلم ومقاصده ومعانيه التي يثكلها العقل والنظر وإعمال الفكر؛ وكفاءته (أي المتكلم) في

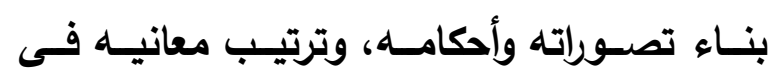
نفسد، وفق نست خاص من العلاقات (النحويـة)، أو استخدام خاص للغة، يجسدها ويجليها. وهو

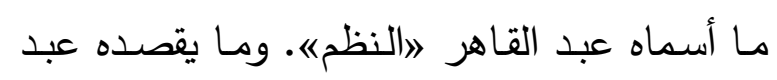
القاهر بالنظم أو توخى معانى النحو، وما يفهـهـ

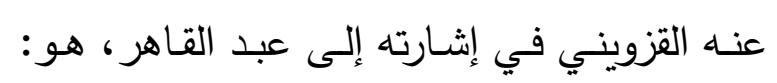

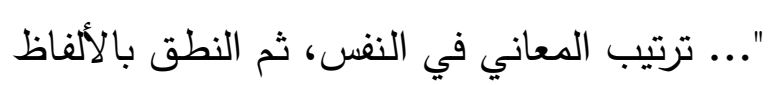
على حذوها .../... بل ليس من فضل ومزية إلا بحسب الموضـع، وبحسب المعنسى الذنى تريـد،

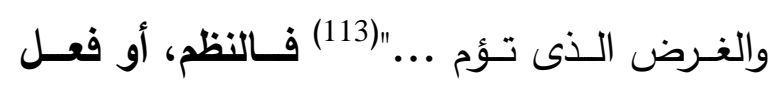
المطابقـة، يستوجب متكلمـاً فـاعلاً يمتلك وعيـاً

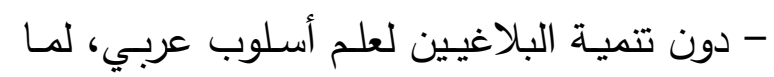

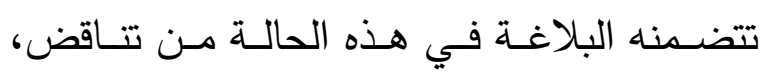

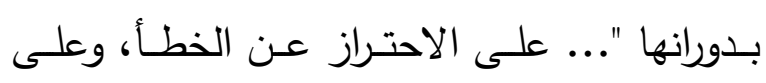

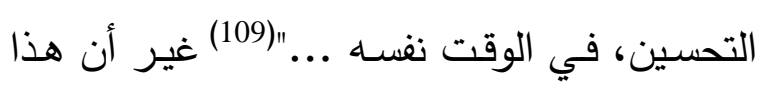

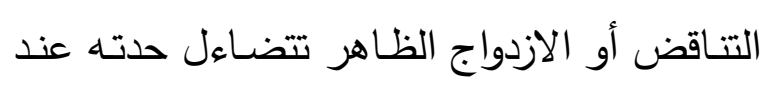

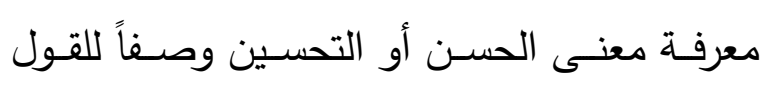

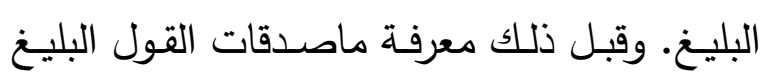
عند السكاكي، في ظل غياب أيّ تحديد لماهية

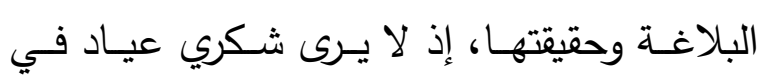

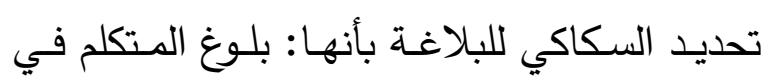

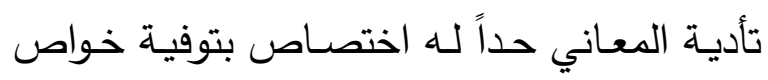
التراكيـب حقهـا، وإيـراد أنــواع التشـبيه والمجــاز والكناية على وجهها؛ لا يراه "... تعريفاً ولا رسماً

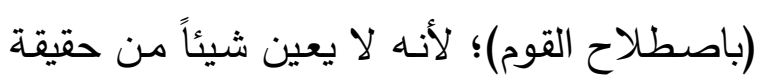

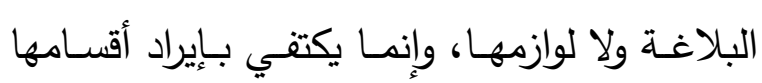

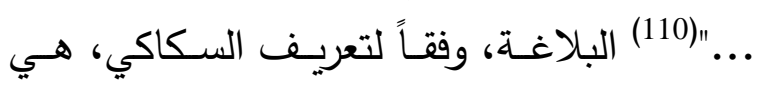
تأدية المعنى المراد، لا بمجرد التأليف بين الألفاظ

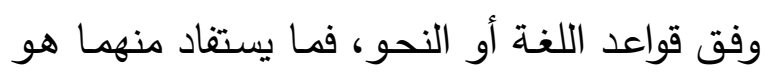

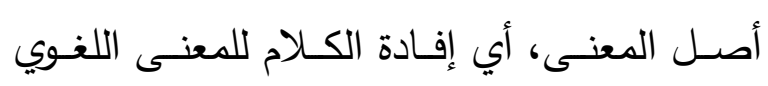

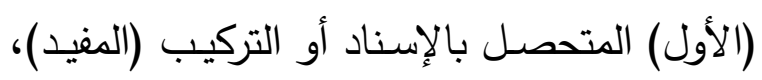

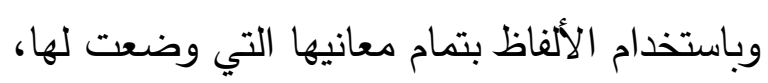
مـن غير تفاوت أو تجـاوز لظاهرهـا، بينما يرتد المعنى المراد - وهو معنى ثانٍ، خاص، زائد على ألى

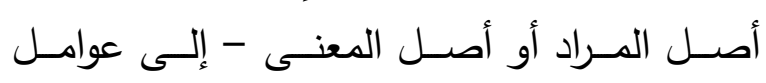

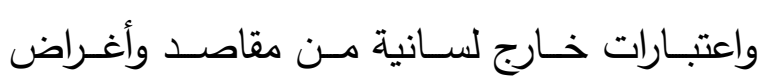
ومقامات تثير إليها خواص وصياغات أو هيئات تركيبية خاصـة، توضـحها، وتبين عنها، ويُستدل

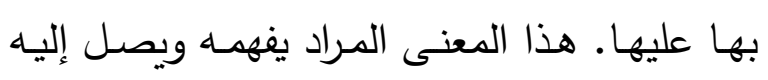
من كان له فضل تمييز ومعرفة بخواص تراكيب 
تطبيـق الكـلام علـى مــا يقتضـــي الحـال ذكـره

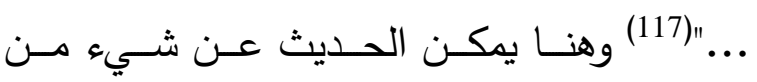
》الاشـتراكي الذي تسـاءل عنه شكري عيـاد بـين علمي المعـاني والبيـان، أي بـين لاتوفيـة خـواص التراكيـب حقهـاه - وهـو موضـوع علم المعـاني، وبين لإيراد أنواع التشبيه والمجاز والكنايـة على وجهاه - وهو موضوع علم البيان؟(118) فالمعاني والبيان، وهما مرجعا البلاغة عند السكاكي، وعند القزويني وشراحه، لا يمثلان علمين متباينين بقدر مـا يثـكلان معرفـة (بخـواص تراكيـب الكـلام، وبصياغات المعاني) "... يُتوصل بها إلى توفيـة مقامـات الكـلام حقهـا ..."(119)، أي معرفـة تتعلق بإنتاج الكـلام (العربي) على وجـا الصـواب وعدم

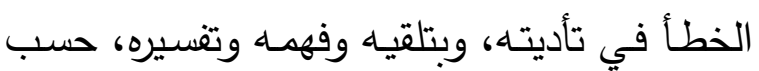
المقاصـ والمقامـات.، ومـا يـرتبط بـذلك مـن تلقي مراد الله تعالى من كلامه، ف".... الواقف على تمام مراد الحكيم تعالى، وتقدس من كلامـه، مفتقر إلى هذين العلمين كل الافتقار ـ فالويل كل الويل لمن تعاطى التفير ، وهو فيهما راجل ..."(120) أي إن البلاغة تمثل سبيل الوقوف على مراد الله تعالى مـن كلامـه، حيـث تمـام المطابقــة بـين المـراد والمنطوق، والإحاطة بجميع اعتبارات القول، بما يجعــل مــن القــرآن أرفــع درجــات البلاغـــة والاستحسان، ومثال 》الحسن المطلقه في القول، ذلك المثال الذي - كمـا يقول شكري عياد "... يجـب أن نفترض فيـه تمـام التطـابق بـين الكـلام

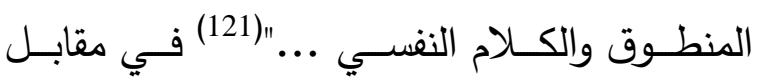
البلاغـات الإنسـانية التـي تكـون فيهـا المطابقــة جزئيـة، ومـن ثـم يكــون الحكـم عليهـا بالصـــة
وقصــاً وقـدرة علـى الفعـل: ترتيب المعـاني في النفس وضم الألفاظ وفقاً له. وإلى النظم يُرجع عبد القاهر - بعد شيء من التردد قال حينه بالتعارض بين النظم والمجاز - مزيـة الكلام وحسنه: مجازاً كان أو غير مجـاز .(114) وهنـا يصـبح المجاز أو العدول باللفظ عن ظاهره، والانتقال منه إلى لازمه أو ما لله تعلق بـه، انتقالاً واضحاً من غير تعقيد معنوي؛ يصبح خاضعاً للمطابقة، وهو ما يعني أن "... اعتبار المطابقـة أيضـاً لا عبرة بها فى بـاب البلاغـة بـدون انتفـاء التعقيـد المعنـوي الذي إنمـا ينتفي بمعرفة الإيراد على الوجه المقبول ..."(115)، أي إن الاحتـراز عـن التعقيد المعنـوي (أي عـدم وضوح الدلالة وتمامها) الذي ينهض به علم البيان

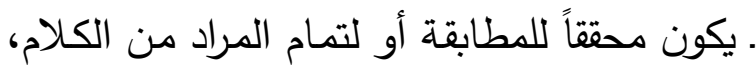
مـن جهـة معرفـة الوجـه المقبـول المناسـب للمقـام ليتـرك غيـره، ممــا يعنـي أن المطابقــة أو تأديــة

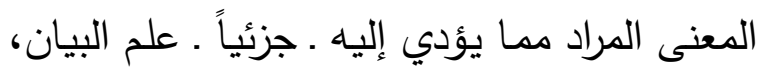
ويعتبر فيـه، على نحو مـا يصـرح السكاكي في تعريفـه لـه. (116) وهكـذا يكـون الحسـن والقبـول المرتبطسان بعلـم البيـان، أو بالصـور والمجـازات، متعلقاً بإيراد المعنى على وجه خالٍ من التعقيد المعنوي، مناسب للمقام، من بين وجوه أو طرق

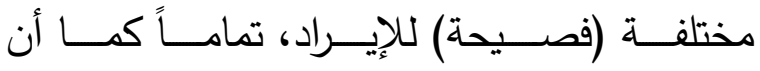
الاستحسـان الـوارد فـي تعريـف السـكاكي لعـــ المعـاني غير منفصـل عن وظيفـة الاحتراز عن الخطأ في إيراد المعنى المطابق أو المناسب، فهو (أي علـم المعـاني): "... تتبـع خــواص تراكيـب إيب الكلام في الإفادة، وما يتصل بها من الاستحسان وغيره؛ ليحترز بالوقوف على ذلك عن الخطأ في 
المقامـات والمقاصــ والأحسوال، وتنحصـر في المحسنات والصور والزخارف. هذا الوضع شبيه بمـا عرفتـهـه بلاغـة اليونـان حيث شعَّل مـا هـو جمالي/ أدبي/ تخييلي، ممثلاً في الصور والوجوه

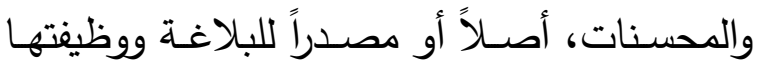
الإقناعية، (123) حيث كان عنصر الأسلوب وبناء

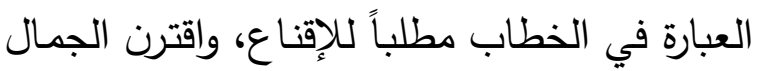

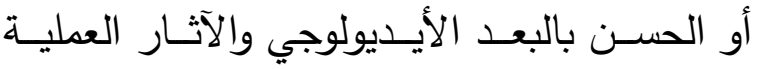
للخطـاب، على نحـو جعل مـن البلاغــة فضـاء

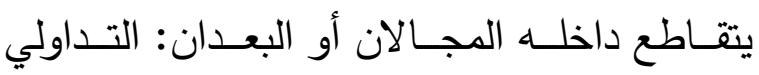
والجمالي، فيتحقق الإقناع بإيجاد الحجة وترتيبها، كمـا يتحقق بصـور التخييل والمحاكـاة؛ والتأثير

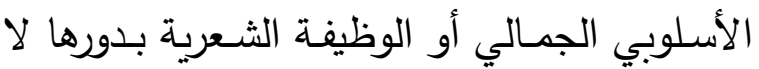

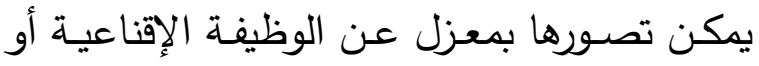

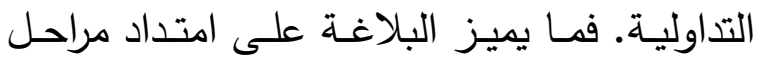
تاريخها، عند الغرب والعرب على السواء، هو لهو النظر إلى الخطاب باعتبار تأثيره وبعده التواصلي جماليـاً وتـداولياً؛ ومـن ثم يتــاخل فـي التحليـل

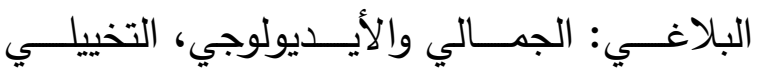
والتـداولي. إنــه يتعلـق بـ"... كـل خطـاب يصـل

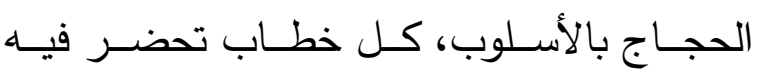

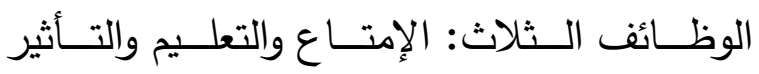
مجتمعة، ويستدعي بعضـها البعض الآخر ؛ كل خطاب يقنع بواسطة الإمتاع والانفعـال، مـدعماً

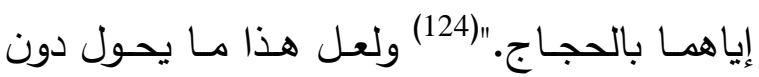

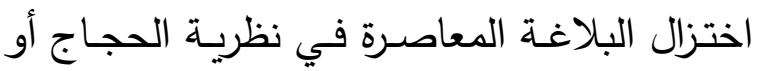

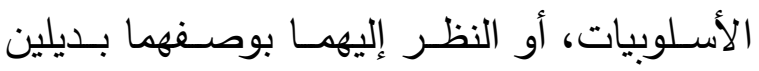

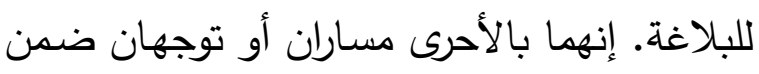
تحـولات أو تتوعـات النظريـة المعاصـرة للبلاغـة:
والخطأ. وهــا إقـرار مـن شـكري عيـاد بتـاخل

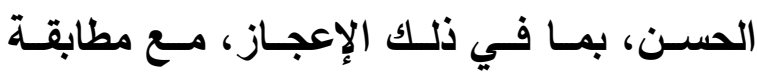
الاعتبار المناسب؛ وبتعلق درجـات الاستحسـان بارجات المطابقة، وبصحة تأدية المراد، والاحتراز عن الخطأ فيها. فليس الأمر من جانب السكاكي والي وغيره من البلاغيين دمجاً بين متتاقضين، ولكنه تداخل أو تقاطع بين مفهومين، يحدث أن يهيمن أحدهما وينحسر الأخر في هذا المشروع البلاغي أو ذاك، وهذا في الواقع ما يثكل تاريخ البلاغة.

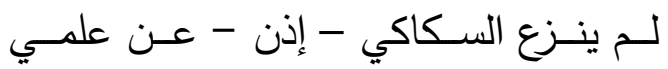
المعاني والبيان صفة التزيين والتحسين، إذ هو لم

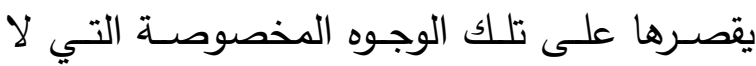
تتدرج تحت العلمين السابقين اللذين تقاسما مفهوم

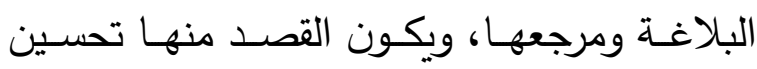
الكلام، والتي شكلت - بتأثير من عمل السكاكي - ما سُمِّي بعد ذلك بعلم البديع. هذه الوجوه التي

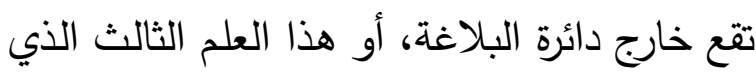

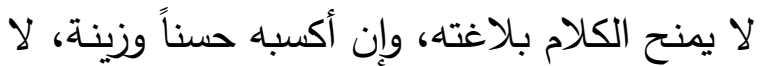
يختص بالتحسين دون بقية علوم البلاغة، على ليل نحو ما يُفهم من قول السكاكي: "وإذ قد تقرر أن لن

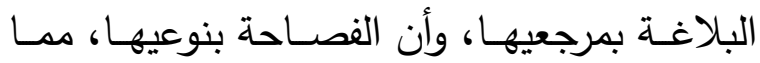

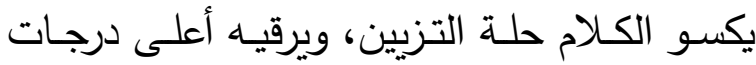
التحسن، فهزنا وجوه مخصوصـة، كثيراً ما يصـار

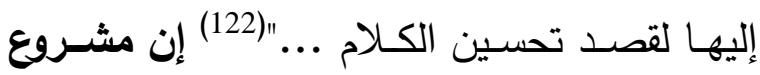

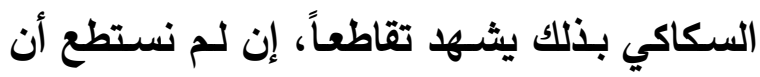

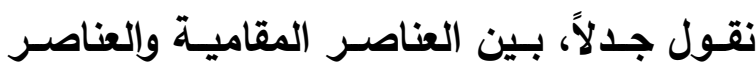

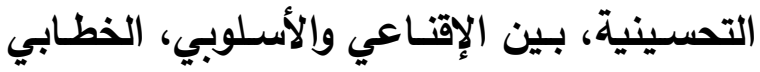

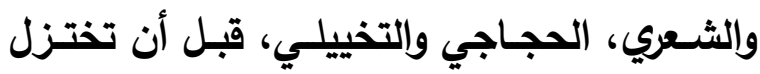

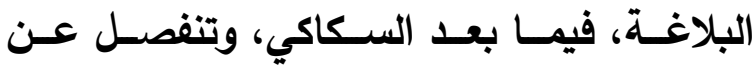


الجانب التحقيقـي من الإبـلاغ، (125) فهذا الجانب في الحقيقة لـم يكن مدار البلاغـة العربية، إذ لـ يكن انشغالها بالمعنى مطلقاً، وفى عمومـه، بل ما تقصــده هـو معنـى خـاص لا يفهـم مسن اللفــا بالوضـع، وإنما يستفاد من المقام. المعنى المقصود هو المراد، أي الأغراض والمقاصد والأحوال التي لا تحيل إلى تصور ذاتي بقدر مـا تتعلق بمـا هو حاصل في الذهن، ومتناسب أو مطابق للأشياء ونظامهــا فـي الواقـع أو في العقـل. إنــهـ مـراد يتناسب مـع مـا هو خـارجي عنـه، مـع نظام كلي مطلـق متعـال قبلـي للعـالم والحقيقـة، قـائم على التطابق والتناسب والاتفاق والاكتمـال، يخضـع له، ويقر بسلطته، كما يعمل على إبقاء هذه السلطة. وتكون اللغة أو الكلام - فى ظل هذا التصور تجلياً لهـذا المـراد، لا بنـاء أو إنشـاء لـه؛ وتكـون بلاغته (أي بلاغة الكـلام) هي بلوغ كمال العالم

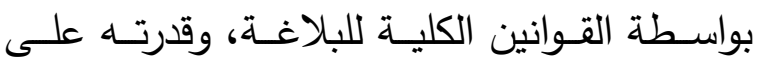
المطابقـة، أي على تأديــة المـراد أو الغـرض أو القصد في تعلقه بنمط عام مثالي متعال. المطابقة لم تكن تتفصل عن قصدية المـكلم فيى اتجاهـه نحـو العـالم أو تعلقـه بـه، وتمثيلهـه وهـذا مـا أدى بالبليغ، ليس إلى الإقصاء التام، بل إلى تقييد دوره وتضـييقه في إنشـاء المعـاني واختراعهـا، بحيـث تحول البليغ ".. إلى فاعلية تابعة لمقتضىى الحال الخارجي المفروض عليه، وتحول إنتاجه (بلاغته) إلى اسـتجابة شـرطية لمـا أطلق عليـه مصـطلح

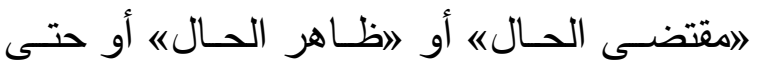

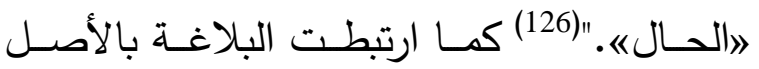
اللغوي للكلمة ـ لدى كثير من البلاغيين . فكانت
بلاغـة الحجــاج، البلاغـة الثـعرية، الأسـلوبيات،

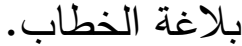
إن الحسـن أو التحسـين أو الاستحســان، الصحة والخطأ، في تعريف البلاغة وعلومها، هي معـايير بلاغيـة، تتعلق بمسـتوى لغوي مفـارق للتعبيـر الوضـعي، فـي تعلقـهـ بـالمعنى المـراد، وتأديته وفق مواضـعات مقامية وأسلوبية، حيث تتهض اللغة بحمل مراد المتكلم أو قصده الذاتي، هذا المـراد/ الفصـــ الذذي لـن يتطـابق تمامـاً مـع دلالات التعبير الوضسعي، فالمطابقـة الكاملـة إنمـا تكون في الألفاظ مفردة، وفي التأليف أو التركيب المبني على الإفادة فحسب. أما فيما عدا ذلك من

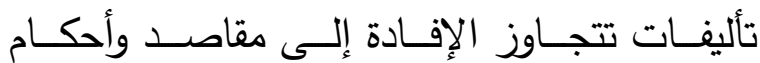

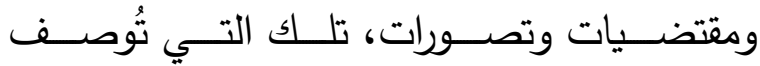
بالبلاغة، فلن تكون اللغة مطابقة أو محاكاة تامـة للمعـاني والأشـياء - وإن أراد البلاغيـون والنقـاد العـرب لهــا (أي التأليفــات البلاغيــة) أن تكــون كالأولى، في نوع من الطموح المبالغ فيه، والتعلق بنموذج مثالي متعالٍ هو القرآن. وفي ضوء ذلك لــم يكـن هنـاك مـا يمنــع مسن اتخــاذ التعبيـرات التداوليـة المألوفـة، ممــا يجـري فـي مخاطبـات الناس، شواهد بلاغية من حيث تعلقها بالقصد/ المراد لا من حيث انتماؤها الأسلوبي (إلى تراكيب البلغــاء أو غيــر ذلــك)؛ كمـــا أن وقـوع هـــهـ التعبيرات/ الشواهد عند أدنى درجات التحسين أو القبول لا يعني أن مطابقتها للاعتبار الذي في نفس المـتكلم، أو عدم الخطأ في أدائسه، يقـف بها، ويقـف بمفهوم الاحتراز عـن الخطأ، عنــ السـكاكي وغيـره مسن البلاغيـين، عنــ مسـتوى 
البلاغية مستقاة من استعمال خاص للفـة في مقام بعينه لله زمنيته وخصوصيته التواصلية، بل

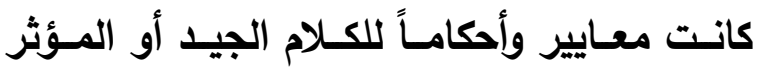
تسـتند إلى أصسول نحويـة، ومنطقيـة، وعرفيـة،

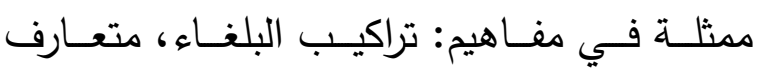

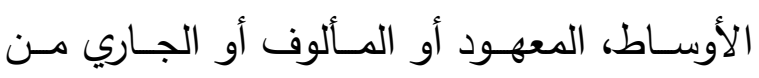
الاستعمال ومـا يتضــنه ذلك مـن شـرط الإفـادة

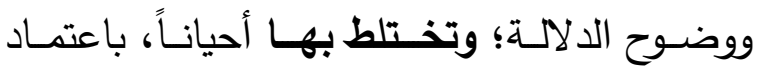
الأصـل النحوي ضـــن الحـديث عـن الاعتبـارات

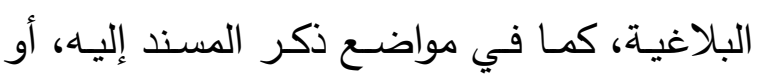

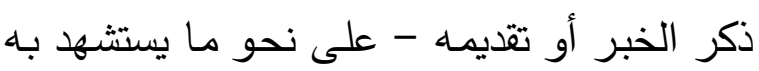

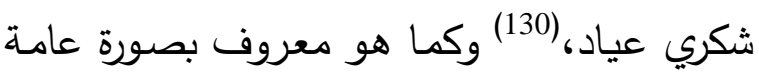
فـي البلاغــة العربيـة، لاسـيما مـن قِبَــلَ شـراح

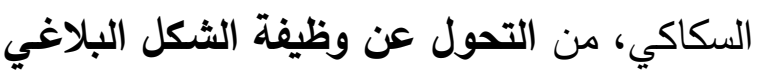

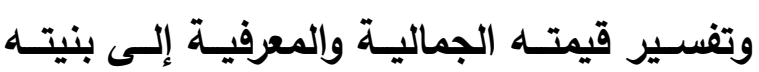

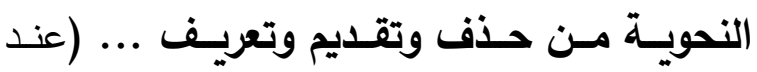

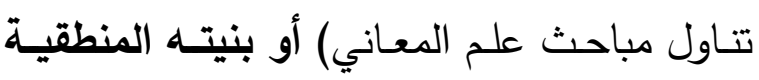
الثكلية من اقتران وتناسب ونقل ... (عند تتاول صور البيان والبديع)، وفق تعليلات أو معسيير

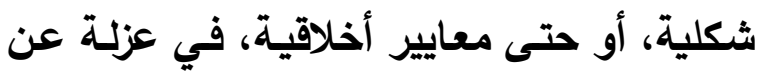
سـياق الــص وصـاحبه؛ إقصــاء للاختلافــات

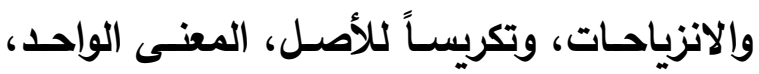

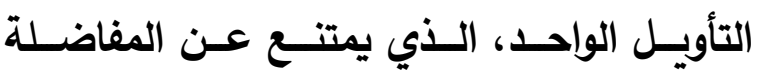

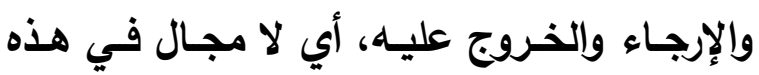

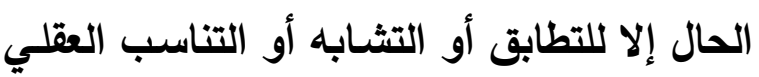

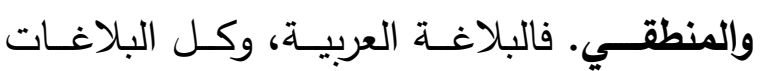
القديمة كما يشير فان دايك Van Djik، كانت

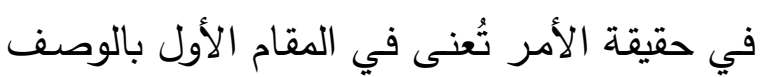

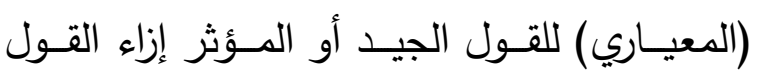

للمعنى وصولاً، بلوغاً، تبليغاً، إنهاء، تقربباً، بكيفية أو طريقة مخصوصـة؛(127) ومن ثم كانت الإبانة والفهم في مقدمة الوظائف التي تؤديها اللغة في مختلف المخاطبات والنصسوص، "... [ف] الإبانـة والإفهام سعى مستويات اللغة كلها، وأما مختلف الوظائف الأخرى . كالوظيفة الأدبيـة مثلاً فوظائف مساعدة دورها تدعيم الوظيفة الرئيسية،

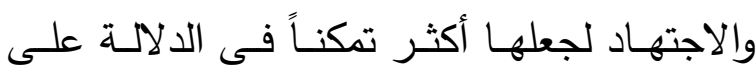
الغرض، وأثد تأثيراً في المتلقي ..."(128) وهو ما لادئ يجعل البلاغة تمتد أيضاً إلى الخطابات والأقوال غير الأدبية. وكذلك كان الحال مع علم الأسلوب الحديث، ليس في بداياته فقط - كما في أسلوبية

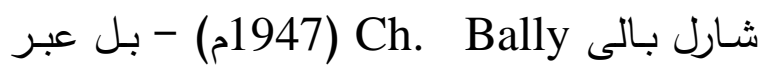

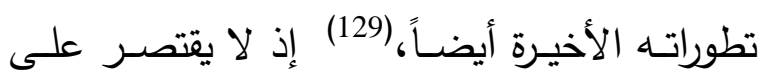
دراسة الخطابات الأدبية، وإن كانت اللغة الادبية الإنة

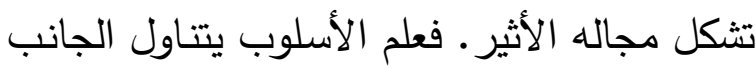
الإبداعي للغة وطاقاتها التعبيرية، وما يرتبط بذلك الكابل

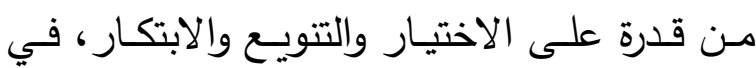
مختلف لاستعمالات، بمـا فيهـا الخطابـات غيـر

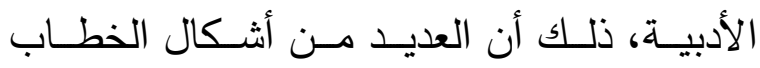

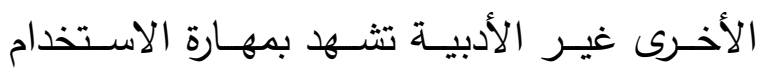

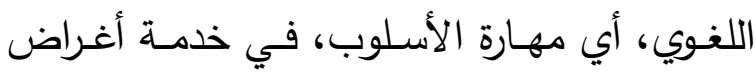

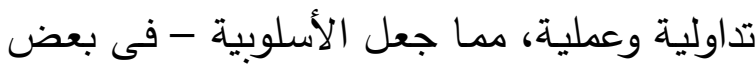
توجهاتها - منهجاً فى التعليم والتعلم، بانفتاحها على طاقات اللغة وتنوعاتها. تتسم بلاغة السكاكي، وغيرها من البلاغات

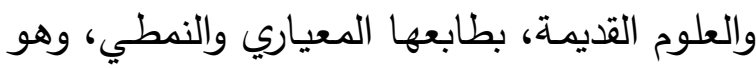

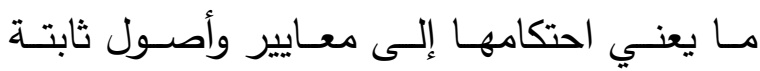
ولازمنية في المجمل، ومن هنا لم تكن الاعتبارات 
أسلوبية، منتهياً إلى مـا يكثف عنه سيبويه من أسـرار وطاقـات كامنـة في طبيعـة اللغــة العربيـة ذاتهـا، حيـث يغـدو "... الاسـتعمال اللغـوي، أي ولي الفعـل اللغـوي في حــ ذاتـه، نشـاطاً مبـدعاً عندـ الإنسان العربي، فهو يتجاوز الأداء المجرد الذي

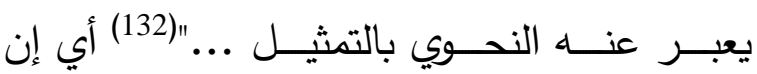
الاستعمال لا يتبع القاعدة أو المثال دائماً.

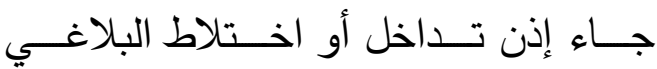
واللسـاني، الجمالي والتداولي، في الوعي العربي، نتيجــة عنايــة البلاغــة بصــورة القــول وشـكله وصـياغته، ومـا يـرتبط بذلك مـن إحكـام الصـنعة، والتحسـين الشـكلي، والتتاسـب العقلي والمنطقي، غيـر أن هـذا الاخـتلاط لا يسـمح بـالقول بـأن المعـايير والاعتبارات البلاغية تتماهى أو تتطابق بصورة مطلقة وشاملة مع تلك الأصول، أو تختزل إليهـا، فاعتبـار المعنـى البلاغـي، أو مـا يســيه شكري عياد 》الأصل المعنوي الدلاليه، لا يطابق الأصـل النحـوي أو قواعد اللغـة، ذلك أن البلاغي لا ينظر إلى التراكيب الواجبة، وإلى الأصل في ذاته، بل إلى ما يشكل عدولاً عن الأصل: وضعاً ومعنى، أو معنى فقط؛ هذا إلى جانب الاحتكام من قِبَل السكاكي كمـا يعلن شكري عيـاد - في تحديـ المعنى (البلاغي) إلى مقتضـى المقـام أو ظروف فعل التكلم، كما في وقوفه على دلالة لام التعريـف؛ يُضـاف إلىى ذلك لجـوؤه إلىى مقـاييس عرفية نسبية من قبيل مفهوم 》متعارف الأوساطه فـي تعيـين بلاغــة مـا فـوق الجملــة: الإيجــاز والإطناب، ولجوؤه كذلك في اعتبار الملازمات بين المعـاني (في حالـة المجـاز والكنايـة) إلى اعتقـاد
الصـحيح الذي يشـكل موضـوع علم النحـو. هـذه الخاصية المعيارية للبلاغة، أي الانشغال بالأقوال في كليتها، التي تشهر مجدداً حضوراً جوهرياً في التطورات الحديثة لعلم اللغـة، وفي علم النص، وكذلك في علم الأسـلوب بوضــع نمـوذج عـام للأسلوب تكون علاقة الأشكال الفردية بالأسلوب كعلاقة الأقوال باللغة؛(131) هذه الخاصية المعيارية أو الكلية للبلاغة قد أدت إلى عدم الالتفات كثيراً إلى نسق المعساني والـدلالات والقيم التي ينتجها القول/النص، والتمسك بدعوى المطالبة بوضوح المعنـى وعـدم خفائـهـ - علـى مسـتى التنظيـر البلاغي والنقدي على الأقل، واصسناع الآليات التي تعود بالمعنى من مجاهل التيه والعماء - إن ولجهــا - إلــى الظـــاهر وحــدود المــألوف مــن الاستعمال، على نحو ما تجلى واضحاً في تحكم المقاييس التداوليـة للخطابـة في الثـعر والمحاكاة والتخييل؛ كمـا أدت المعياريـة إلى غيـاب التفكير في حقيقة العلاقة بين الدال والمدلول، مما كان لله أثره في تهميش جانب الاستعمال الفردي للغةة، أي الجوانـب الأتيـة فـي الأســلوب، أو علاقـة الكـلام بصـاحبه - تحاشياً لتتاولها بالنسبة للنص القرآني - في مقابـل العنايـة بـالمظهر اللغوي أو الثكل أو الصياغة، أو الإعلاء من صور نمطية عامـة للأقوال أو الأسـاليب، تأتي تحت تسميات: معهود العرب، سـن العرب وطـرقهم في القول، متعـارف الأوسـاط ... وغيرهــا؛ أو اللجـوء إلـى أشكال افتراضية لا تشهد تحققاً أو استعمالاً، مثل مصطلح 》التمثيل الذي لم يُتكلم بـه/ الوارد عند سيبويه، والذي رصده شكري عياد، وقرأه من وجهة 
تصرف بحرية في تثكيل خطابه، فهو يقر للغة بإمكاناتها التعبيرية، ويعرف حدودها، في الوقت الــي قــ يثــارف حينـاً أقصــاها، وحينـاً أخـر يتجاوزها، غير مكثرت بمواضعاتها، فيخرجها عن معياريتها، ويحمُّلها بقيم تعبيرية خاصة ومغايرة،

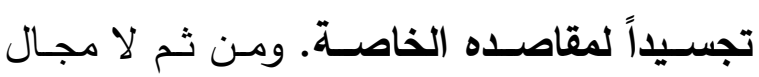
للحديث عـن 》أصـول نحويـة مطابقـة للأصـول المعنويــةهة، ولا مجــال للدهثـــة أو الاســتغراب بـافتراض نظـر البلاغـي فـي التراكيـب الواجبـة،

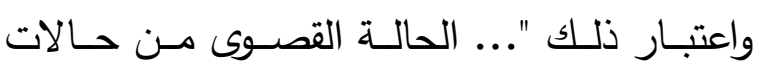
اعتمـاد السـكاكي على التفكيـر النحـوي، وقبولـهـ

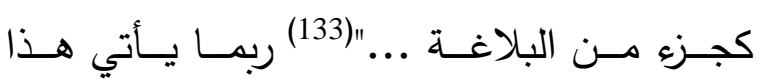
التداخل، أو حتى الاختلاط، كمـا تأتي محساولات

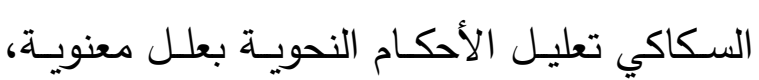
وإدراجه بعض الاستعمالات مثل أسلوب التعجب لعبد ونحوه، ومجيء الفعل الماضي بعد إذا؛ ربما يأتي هـذا مـن جانبــهـ فـي إطـار بيـان الخصــائص الأسـلوبية والفنيـة للغــة العربيـة بوصـفها نظامـاً،

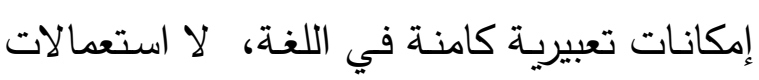
وتحققات فردية، أو ما يمكن تسميته، على طريقة فوسلر وبـالي، علم أسلوب اللغـة (العربيـة). هذا الجانـب مـن الدراســة الأسـلوبية لا ينكـره شـكري عياد، حين يقر، لإجراء أي بحث في الأسلوب، بضرورة الرجوع إلى ما يَعُده قواعد أو علم أسلوب

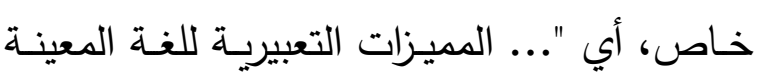
التي كتب بها العمل الأدبي أو مجموعة الأعمال

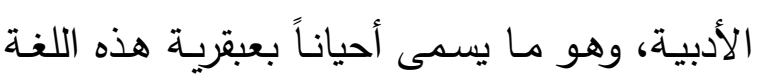

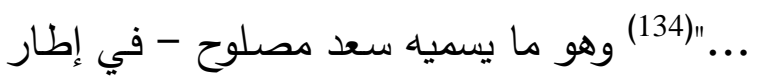
إعـادة صـياغة مشـروع السكاكي - بـأسـلوبيات
المخاطب، عرفياً كان أو غير عرفي، وإلى الترابط المبنـي علـى المخيلـة؛ وبالجملــة إرجاعــه هـــه

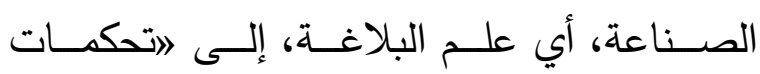

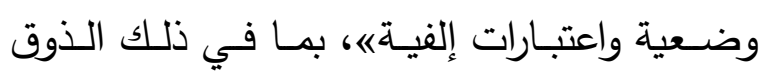

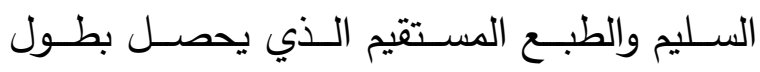
مدارسـة. قـــ لا يخـرج الأمـر فـي الحـالين عـن إخضـاع التعبيـر لمعـايير نمطيـة ثابتـة وحاكمـة: اللغـــة العامــة، والاعتبـارات المقاميـة، غيــر أن البلاغـة العربيـة قد أظهـرت في بعض مباحثهـا مرونـة عجيبـة في التعامـل مـع اللغــة، بالتوسـع وتجاوز العرف والعدول عن القاعدة؛ وفي اعتماد

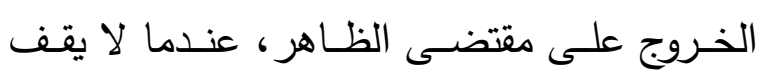
المـتكلم عنــــ تلبيــة توقعــات مخاطبيــه ومراعـاة حالاتهم الإدراكية من خلو ذهن أو تردد أو إنكار، وإنما يتعامل مع المخاطب بوصفه متلقياً محتملاً، يمنحه وجوداً متخيلاً داخل عمله، فيتحول التعبير بـذلك مـن إخبـار إلى فعـل جمـالى، مـن الوظيفـة

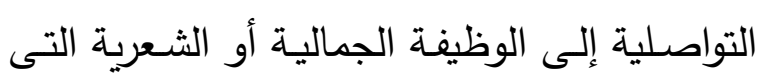
تجسد مقصداً جمالياً أو بلاغياً. وبعبارة أخرى: لا لا لواهئه يعود التعبير خطاباً للمتلقى بمـا يطلبه ويقتضيه ظاهر حاله، بل بما يتخيله المتكلم أو يعتبره عن يُ ئن

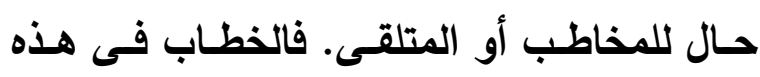
الحالــة يصـبح علاقـة متخيلـة بـين المـتكلم والمتلقى. كذلك لا تعود المقامـات - التي يبدي

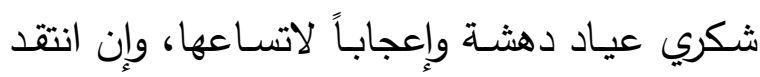
حصـرها وتصـنيفها - معـايير خاضـعة للتحديـد المنطقي الشكلي، إذ يصبح لها في هذه الحالة من

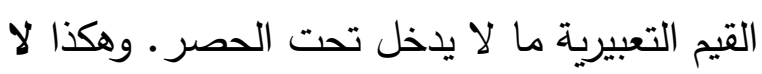
تخلو البلاغة من نظرة إلى المتكلم/ المبدع وقد 
النصوص الأدبية الحديثة وتطور أشكالها، والتي

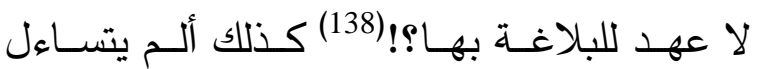
شـكري عيـاد عمــا يميـز الأسـلوب أو الظـاهرة الأسـلوبية مـن قوانين عامـة للتفرد والخصوصسية، تناظر مفاهيم أخرى مجردة كاللغة والعرف اللغوي، لكنها لا تغني عن اكتشاف النظام الخاص لكل نص؟! وهو ما لم تكن البلاغة العربية في فهمها للأسلوب بعيدة عنـه، حين اقتربت بـه، فيما يرى شكري عياد، من مفهوم النوع الأدبي أو القوانين العامـة، وإن جاء ذلك دون بحث مفصل للسمات أو طرق الصياغة المميزة.(139) غير أن مواجهـة النص الأببي، والكثف عن الأسلوب الثخصي، يبقى في الحقيقة جوهر اختبار فرضية البديل أو الـتلاقح بـين البلاغـة العربيـة وبـين اللســانيات ومنـاهج النقــ الحـديث - على نحو مـا حاولـه شـكري عيـاد بصـورة أكثر وضـوحاً في تحليــه لميمية المتنبي في وصف الحمى، الذي بدا تحليلاً بلاغياً أسلوبياً نقدياً.
اللغةه التي تتأسس من مجموعة العلوم والمعارف التي يطلق عليها السكاكي علم الأدب، بمـا في ذلك علم البلاغـة بفروعـه الثلاثة؛ والتي تتــاول "... الطاقات الأسلوبية التعبيرية الكامنة والمحتملة في لغـة بعينها. وهذه الطاقات هـي المـادة الغفل التي يعمل فيها المنشـئ بالتشكيل ليصـوغ النص تبعــاً لقدراتــهـ واختياراتـــه والمحــددات التعامليـــة (البراجماتيـة) التي تحكم إنتـاج النص واسـتقباله ..."(135) والحـق أن البلاغــة العربيـة قد عملــ، بدراستها للأسـاليب: هيئاتها، وتفاوتها، وارتباطها بالمقامـات، على تطور النظر في إمكانـات اللغـة العربيـة، بمـا يقارب مـا يُسـى حديثاً علم أسلوب اللغة - خلافاً لعدم تسليم بعض النقاد بمثل هذه المقاربــة(136) - وهـو أيضــاً مـا يمكـن أن يمثـل استشـرافاً لأفق موضـوعي في تأمل اللغـة وبحث طاقاتها الكامنة والمستكنة. فالأساليب، التي غدت معايير واعتبارات لها سلطتها على القول وتحكمها فيـه، والتي كانـــــي الوقـت نفسـه بعيدة عـن الملامـح الذاتيـة، هـي في الأسـاس تصـرفات في اللغــة بمـا تقتضــيه المقامــات، تتعلـق بغايـات تواصلية ومقاصد جمالية، وتعيد صياغة مـا يقره العرف اللغوي العام، وما يجري على الألسنة من اســعمالات. إنهـــا بمثابــة "... تثــفير المنجـز انطلاقـاً مـن السـنـن اللغويــة المتواضــع عليهــا،

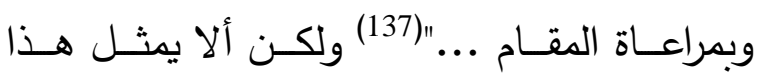
الوضـع مـن جانب البلاغـة العربيـة مطلباً لبعض الأسلوبيين، بالتطلع إلى تشكيل الوعي الأسلوبي

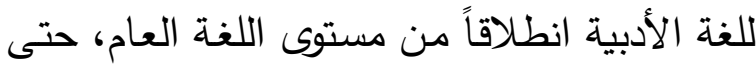
مـع الإقرار لهم بالتتوع غير المحدود في أجناس 
تسـتطيع أداء وظليفتهــا، لا ســيما المعياريــة الهوامش والمعرفية، دون اتفاق بشأن التبرير العقلي، أو

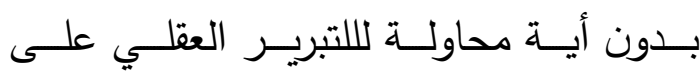
الإطلاق: توماس كون، بنية الثورات العلمية. ترجمـة: شـوقي جــلال. (المجلـس الـوطني للثقافة والفنون والآداب، الكويت، سلسلة عالم المعرفــة، ع164، ديســمبر 1992م)، ص. 83. وانظر عرض هيلي لأطروحة كُون في:

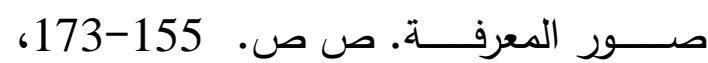
وبخاصة ص ص. 160، 173. 4-صـلاح فضل، بلاغـة الخطاب وعلم النص. (المجلس الـوطني للثقافـة والفنــون والآداب، الكويــت، سلســلة عــالم المعرفــة، ع164، أغسطس 1992م)، ص. 119. وانظـر قولـه بأنـا إذا كان التعـالي المعيـاري قاسماً مشـتركاً بين كل البلاغـات القديمـة، فبإن السمة التي لازمته في البلاغة العربية، وهي تجاهل فوارق الأجناس الأدبيـة، قد جعلتها اكثر إمعانـاً في الصـورية وغيـر التاريخيـة. (بلاغـة الخطـاب.

ص. 5- جان كوهن، بنيـة اللغة الثـعرية. ترجمة: ححمـ الولي وحخد العمري (دار توبقال للنشر ، الدار البيضـــاء، ط1؛ 1986م)، ص.47. ويــكر

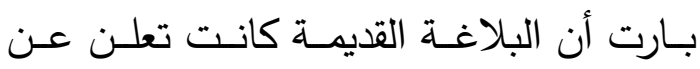

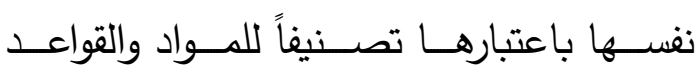
والأقسـام والأجنـاس والأسـاليب: رولان بـارت،

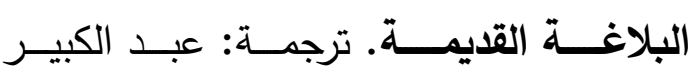
الشرقاوي. (نشر الفنك للغة العربية، المغرب،

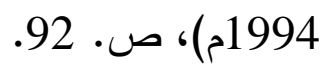

1-باتريك هيلي، صور المعرفة: مقدمة لفلسفة العلم المعاصرة. ترجمة نور الدين شيخ عبيد.

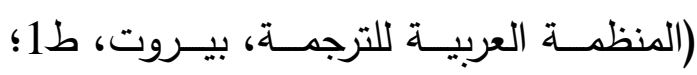
2008م)، ص. 28. وهيلـي هنـا يقـارن بـين الغرض من العلم في عمل أرسطو وبين مـا

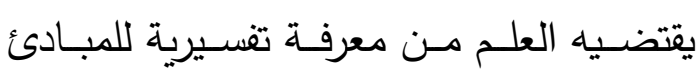
الكليـة. ويمكن الرجـوع إلى (ص. 139 ومـا بعدها) للتعرف على موقف كارل بوبر من نقد هيوم للاستقراء، مؤسساً عليه تمييزه بين العلم واللا-علم.

2-سـعد الدين التفتازاني (ت 792هـ)، المطـول شـرح تلخيص مفتـاح العلـوم. تحقيق: عبد الحميد هنداوي. (دار الكتب العلمية، بيروت،

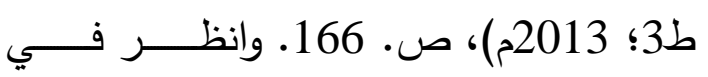

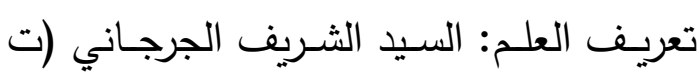
816هـ)، كتاب التعريفات. تحقيق: عبد المنعم الحفني. (دار الرشـاد، القاهرة، 1991م)، ص ص. 177 178، 178 (17) 3-راجع تمييز القنّوجي بين: المبادئ، الأصول، المصادرات، وهو بصدد حديثه عن المعلومات المستعملة في العلوم لبنـاء مطالبها المكتسبة عليها: صديق بن حسن القنّوجي (ت 1307

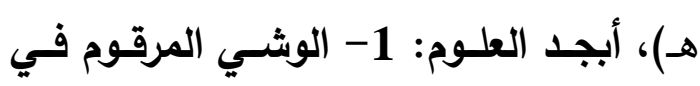
بيان أحوال العلوم. نشره: عبد الجبار زكار .

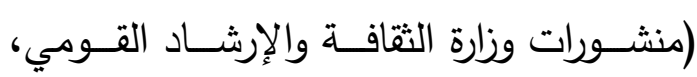
دمشق، 1978م)، ص ص. 47، 48. ويذكر توماس كُون أن النماذج الإرشادية أو المعايير paradigms حين تبقى آمنـة ومؤكدة، فإنها 
10- انظـر حـول عمليـات توسـيع البلاغــة وتطويرها عند جماعة مو، انظلاقاً من إعادة

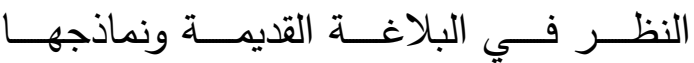
التصنيفية، مع استبعاد طابعها المعياري: - مجموعة مو، بحث في العلامـة المرئيـة: مسن أجل بلاغة الصـورة. ترجمة: سمر ححم سعد.

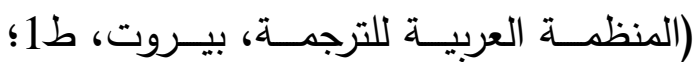
2012م)، ص ص. 13، 14 • 14 - حمحـ مشبال، البلاغـة والأدب: مـن صـور اللغـة إلــى صـــور الخطــاب. (دار العـين للنشـر ، القاهرة، ط1؛ 2010م)، ص. 55 وما بعدها. - أحمــ درويش، الـنص البلاغـي فـي التـراث العربي والأوربي. (دار غريب للطباعة والنشر والتوزيـع، القـاهرة، 1998م)، ص ص. ص. 7، 8. حيـث ينقـل عـن الجماعـة تفسـيرها لعملهـا بقولها: "اإن الجماعة تعيد تقديم البلاغة تبعاً للتصـورات الحديثة، لكي تهبها المكانـة التي تستحقها في تراثنا. وهي تعتمد في ذلك على نتــائج دراســات دي سوســير وهيلمســليف وبنفينسـ، وكذلك على دراسـات جاكوبسون اللغوية، وعلى النظريات الادبية الحديثة. وهي تعتمد على وصـ/ العناصـر الأساسية في صور التعبير ، وعلى الربط بين البلاغة وعلوم

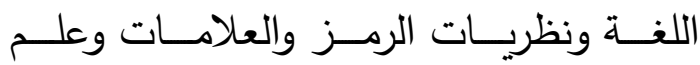

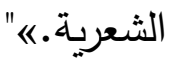

11- يرى بول ريكور أن المدونـة عندما تكون مجهـزة مسـبقاً، وثابتــة، ومغلقـة، فهـي بهـذا المعنى ميتة، وإن كان ريكور يذكر ذلك على سـبيل الـذفاع عـن شـرعية التحليـل البنيـوي

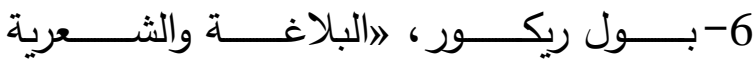
والهرمنيوطيقـا،ه ترجمـة: مصــفى النحــال. مجلـة فكر ونقد. (دار النشر المغربية، الدار البيضـاء، س2، ع16، فبراير 1999م)، ص.

7-باتريك هيلي، صور المعرفة. ص. 22. 8- انظر حول حقيقة اللسان، وعلاقة اللغة بالواقع والفكر : روبير مارتان، مدخل لفهم اللسـانيات - إبستيمولوجيا أولية لمجال علمي. ترجمة: عبــــ القـادر المهيــري. (المنظمــة العربيــة للترجمـة، بيـروت، ط1؛ 2007م)، ص. 65 وما بعدها، ص ص. 121-125. كما يمكن الرجوع في النسبية اللغويـة إلى بنيامين لي

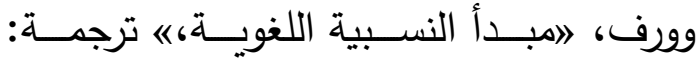
ميثـال زكريـا. ضــن كتاب: الألسـنية: علـم اللغة الحديث - قراءات تمهيديـة. (المؤسسة الجامعيـة للدراسـات والنشـر والتوزيـع، بيروت، ط2؛ 1985م)، ص ص. 161-163. 9-راجـع حـول وضــعية النــوذج اللسـاني في التحليل البنيوي، وما وُجِّه من نقد إلى شعريـة

$$
\text { ياكوبسون في: }
$$

- عثــاني الميلـود. الثـعرية التوليديـة: مــداخل نظريـة. (شـركة النشـر والتوزيـع - المـدارس، الدار البيضـاء، ط1؛ 2000م)، ص ص. 22 $.24-$ - جوناثان كلر • الثعريـة البنيويـة. ترجمة: السيد إمـام. (دار شـرقيات للنشـر والتوزيـع، القـاهرة، ط1؛ 2000م)، ص ص. 21-49، وبخاصــة ص. 44؛ ص. 99 ص 99 
الشعري في القرن التاسع عشر • ويشهد صمود - في سياق حديثه عن الخطابة الأرسطية بوقوع العكس. فالبلاغة الأرسطية في جوهرها تقـوم على الاخـتلاف بـين صـناعتيّ الثـعر والخطابـة: وسـائل ومقاصـــ. وتكف الخطابـة

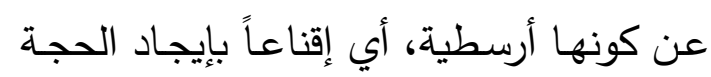
وترتيبها عندما يرفع التعارض بين النشاطين، وينصـهران في بوتقة واحدة، وتصبح مقررات

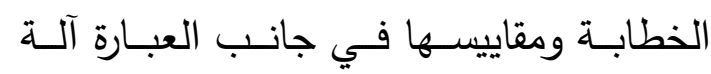
الثـعر وعيـاره، بعـد أن كانــت وظيفتـهـ إيقـاع المحكيات بالإيحاء والتخييل. (حمادي صمود، مـن تجليـات الخطــاب البلاغـي. ص ص. ص. .129 107

18- حمـادي صـمود، مـن تجليـات الخطـاب

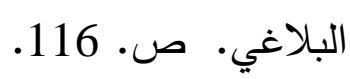

19- حسازم القرطـاجني (ت 684هـ)، منهــاج البلفـاء وسـراج الأدبـاء ـ تحقيق: عحد الحبيب بن الخوجـة. (دار الغرب الإسـلامي، بيروت، ط3؛ 1986م)، ص ص. 19، 20. وقد سبق أن اعترف 》ابـن الأثير ش،، بمثل هذه التفرقـة

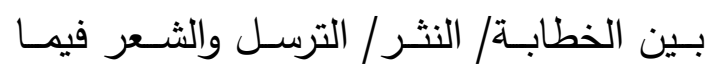
يتعلـق بالوضـوح والخفــاء أو الغــوض، فـي قوله: "...إن طريق الإحسان في منثور الكلام يخـالف/ طريـق الإحسـان في منظومسه؛ لأن

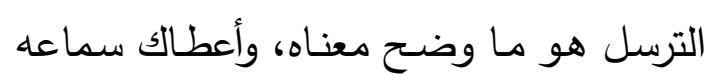
فـي أول وهلــة مــا تضـــنته ألفاظـهـ؛ وأفخـر الشعر مـا غمض، فلم يعطك غرضـه إلا بعد

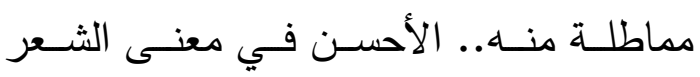
الغــوض، وفـي معــني الترسـل الوضـوح."
وانتصــاره: بـول ريكـور ، صــراع التـأويـلات: دراسات هرمنيوطيقية. ترجمة: منذر عياشي.

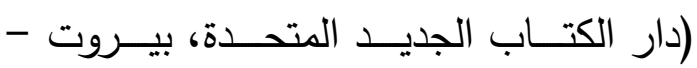
بنغازي، ط1؛ إب 2005م)، ص. 116. 12- جوناثـان كلـر • الثـعرية البنيويــة. ص. صل .49

13- مصطفى ناصف، "بين بلاغتين، شهن ضمن

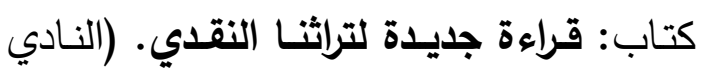
الأدبـي الثقـافي، جدة، 1988م)، جـ2، ص. جلـ .382

14- حمـادي صــود، مـن تجليـات الخطـاب البلاغي. (دار قرطاج للنشر والتوزيع، تونس، ط1؛ 1999م)، ص. 121. 15- عبدالسـلام المسدي، التفكير اللسـاني فى

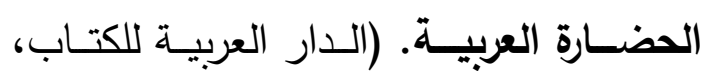
طرابلس . تونس، 1986م)، ص. 75. 16- يذكر بارت، في حديثه عن بداية ظهور

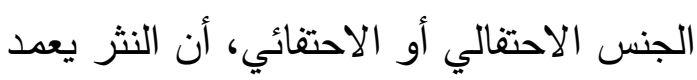

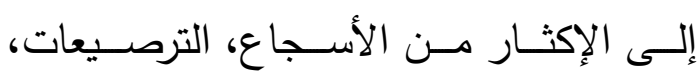
التجانسـات الاسـتهلالية، تـــاظر الجمـل بوصفها تعويضاً عما فقده من سنن الثعر من وزن عروضسي وموسيقى: رولان بارت، قراءة جديدة للبلاغة القديمة. ترجمة: عمر أوكان. (أفريقيا الثرق، الدار البيضاء، 1994م)، ص ص. 16، 16، 17 (17. 17- يشير حمـادي صـمود إلى شرح ج. قـارد تامين لقصـيدة بـودلير المشـهورة 》النـورسهي، حيث اهتمت بنوع من الاستدلال مبني على المثل، لتبيان تحكم آليات الخطابة في الإبداع 
والتداولي بعفويـة، من أول نشأتها إلى عنفوان تضــارب مـذاهبها. (تحمد العــري، البلاغـــة العربية: أصولها وامتداداتها. (أفريقيا الشرق، الدار البيضاء ـ بيروت، 1999م)، ص. 30.) وضـــن السـياق نفسـه يـذكر محهد مشـبال أن الثـعر في النظريـة البلاغيـة عند العـرب لـم يكن سوى ميدان للحجج، فهو صياغة عقلية أقرب إلى حدود المنطـق منهـا إلى مقـاييس الفن الثـعري، أسـهمت فيهـا العوامـل الدينيـة

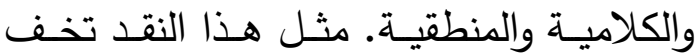
حدته عند الوعي بأن التأثير الجمالي قد ينشأ على أسـاس تـداولي، بمـا يســح بـالقول بـأن الوظيفـة الشـعرية لا يمكن تصـورها في كثير مـن الأحيـان بمعزل عـن الوظيفـة الإقناعيـة. والثعر العربي القديم يشهد بتداخل الوظيفتين، بـل يتأسـس عليـه، ولا يكـاد يعـرف الفصـل بينهما، فقد كان خطاباً عملياً شديد التأثير . (حمح مشـبال، البلاغـة والأدب. ص ص. 32،

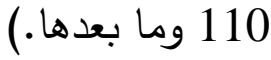
20- يـرى صـلاح فضـل أن التعـالي المعيـاري الدائم الذي كانـت عليـه البلاغـة التقليديـة قد أدى إلى انفصـام حـاد بين الأشكال والأحكام البلاغية من جانب، والإبداع الأدبي والثعري من جانب آخر، حتى ليمكن القول بأن هذا الانفصـام يعـد السـمة المميـزة لهـذه البلاغـة التقليدية، بل إن هذا التعالي قد أعاق البلاغة العربيـة عـن بنـاء جهاز متكامـل قـادر على لــ اسـتيعاب التحــولات الأدبيــة التاليـة للعصـر النــوذجي عنــدهم. (صــلاح فضـل، بلاغــة
(ضياء الدين بن الأثير (ت 637هـ)، المثل السـائر فـي أدب الكاتب والثــاعر . تحقيق : أحمــد الحـوفي وبـدوي طبانــة. (دار نهضــة مصـر للطباعـة والنشـر ، القــاهرة، د.ت.)،. جـ4، ص7.) وانظـر تأكيـده علـى تـداخل البعدين: الإقناعي والتخييلي داخل الخطـاب، وتبعيــة أحسـدهما للآخــر بحسـب الجــس التعبيـري: الثــعر أو الخطابــة، وكيـف أن الأقاويل المقنعـة الواقعـة في الثـعر ينبغي أن تكون تابعـة لأقاويـل مخيلة، مؤكدة لمعانيها، مناسبة لها فيما قصد بها من الأغراض، وأن تكون المخيلـة هي العددة. ( منهاج البلغـاء. ص. 62 ومابعـدها.) ويقـدم الفـارابي تحلـيلاً لوقــوع التخييــل والمحاكـــاة الثــعرية فــي المخاطبـات، حيـث يقـول: "... إن الإنســان كثيراً مـا تتبع أفعالـه تخيلاتـه أكثر مدا تتبع ظنه وعلمه، فإنه كثيراً ما يكون ظنـه أو علمها مضــاداً لتخيـــه، فيكـون فعلـهـ الثـيء الـــي بحسب تخيله، لا بحسب ظنـه أو علمهـ، كمـا يعـرض عنـــ النظـر إلـى التماثيـل المحاكيـة للشيء، وإلى الأسماء الثبيهة بالأمور ·/ وإنما تستعمل الأقاويـل الثـعرية في مخاطبـة إنسـان يسـتنهض لفعـل شــيء مــا باسـتقرار إليــهـ واسـتـراج نحـوه." (أبـو نصــر الفــارابي (ت 339هـ)، إحصـاء العلـوم. تحقيق: على أبو ملجـم. (دار ومكتبــة الهـلال، بيـروت، ط1؛ 1996م)، ص ص. 42، 43.) ويتحـدث تحمد

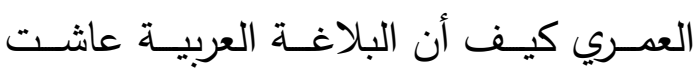
إشــكالية الحــوار أو الصــراع بــين الثــعري 
علم الأدب/ البلاغـة وعلاقاتها، والغايـة منها، واســتنادها إلـى فكــرة التمــام أو الاكتــــال: السكاكي (ت 626هـ)، مفتاح العلوم. ضبطه

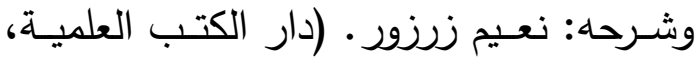
بيـروت، ط1؛ 1983م)، ص ص. 6، 6، 7، 8، 162، 432، 435، 513، 514. 25- أبـو حامـد الغزالي (ت 505هـ)، ميـزان العمل. تحقيق: سليمان دنيا. (دار المعـارف، القـاهرة، ط1؛ 1964م)، ص. 349. وانظـر الفكـرة ذاتهـا، أي التراتـب الضــروري للعــوم والمعـارف عنـد: القنّوجي، أبجد العلـوم: 1الوشي المرقوم في بيان أحوال العلوم. ص. 126. ويتحـدث ابـن حـزم عـن تعلـق العــوم بعضـها بـبعض، وكيف أنـه لا يسـتغني علـم

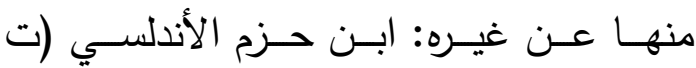
456هـ)، 》رسـالة مراتـب العلـوم،هـ ضــن : رسـائل ابـن حزم الأندلسـي. تحقيق: إحسـان عباس. (المؤسسـة العربيـة للدراسـات والنشـر ، بيروت، ط1؛ 1983م)، ج4، ص. 81. 26- ابـن خلـدون (ت 808هــ)، المقدمـــة. تحقيـق: عبدالسـلام الشــادي. (بيــت الفنـون

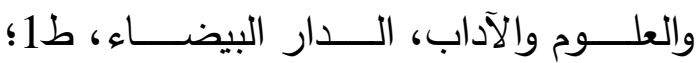
2005م)، ج3، ص. 69. وانظــــر حديثــــه تفصيلاً عن علم تعبير الرؤيا وحقيقتها: ص

$$
\text { ص. }
$$

27- الثــوكاني (ت 1250هـ)، أدب الطلــبـ ومنتهـــى الأرب. تحقيـق: محهد بـن يحيـى السّربحي. (دار الكتب العلمية، بيروت، طما؛ 2008م)، ص. 156. وحـول تحـول صـناعة

$$
\text { الخطاب. ص. } 109 \text { وما بعدها.) }
$$

21- إرفـنج هـاو، 》افكـرة الحـديث في الأدب والفنـون، ضــن كتاب: الخيـال، الأسـلوب، الحداثــة. اختيـار وترجمـة: جـابر عصـفور . (المجلـس الأعلــى للثقافــة، القـــاهرة، ط1؛

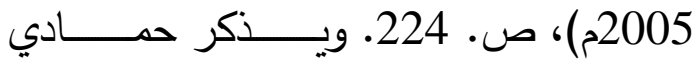
الرديسـي أن الحداثــة تقــدم نفسـها كنظريــة تأسيس فلسفي للعـالم، يـتم فيـه إيـلاء الأولويـة

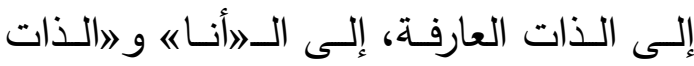
الكامنـةه، تلك التي، كقيمـة أســى، تضـلع بـالمعنى، وتبنـي العـالم، وتؤسـس الرابطــة الاجتماعية، وهو في ذلك ينهل من 》كاتالوغ《 مـن القـيم: الحربــة، الفـرد، العقـل، الكونيـة،

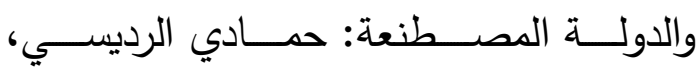
》الحداثة والتحديث، ش ضـمن كتاب: الحداثـة وانتقاد|تها: r-نقد الحداثة من منظور عربي إســلامي. إعـداد وترجمــة: محهـ سـبيلا وعبـد السـلام بنعبــد العـالي. (دار توبقـال، الـدار

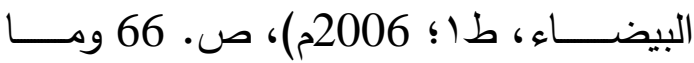
بعدها.

22- جورج كانغيلام، دراسات في تاريخ العلوم وفلسفتها. ترجمـة: ححمد بـن ساسـي. (المنظمـة

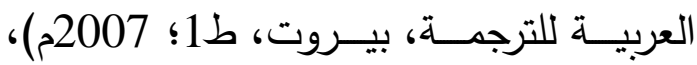
ص.

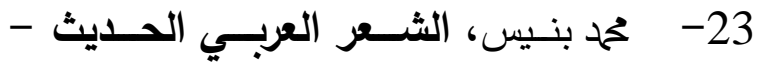
بنياته وإبدالاتها: 4- مساءلة الحداثةة. (دار توبقال للنشر، الدار البيضاء، ط3؛ 2014م)،

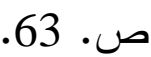
24- راجـع تأكيد السـكاكي على تراتبيـة فروع 
33- يقول جان بول دومون: "... اليس العلم

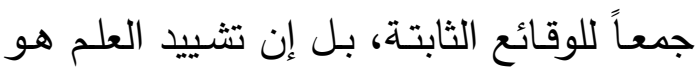
شرح ما لا يخفى على أحد، مع التعبير فوق ذلك عن الأسباب العقلية التي تسلك في نظام واحـــ مجمـوع الملاحظــات المنتثـرةه": بيـار لرتومـا، مبـادئ الأسـلوبيات العامــة. ترجمـة: محمد الزكــراوي. (المنظمــة العربيــة للترجمــة، بيروت، ط1؛ 2008م)، ص. 12. 34- محمد مفتاح، "اتقديم ...6، كتاب: البلاغـة والســلطة فـي المغـرب: أحمـــــن محمد بـن يعقـوب الـولّالمي. لمؤلفـه: عبد الجليـل نـاظم. (دار توبقــال للنشــر، الــدار البيضــاء، ط1؛

$$
\text { 2002م)، ص. ص. } 11
$$

35- يتساءل حسين علي عن احتمالية استقلال

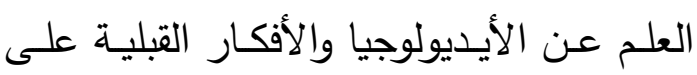
نحـو يحمـل مقتضـى سـؤاله إثباتـاً لأولوبـــة

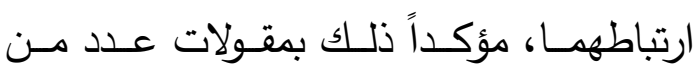
فلاسفة العلم أمثال: كارل بوبر ، توماس كون، إمري لاكاتوش وغيرهم يقول متسائلاً: "... هل تنفلت القوانين العلمية والكشوف والموضوعية التي ينطوي عليها العلم من الثروط التاريخية

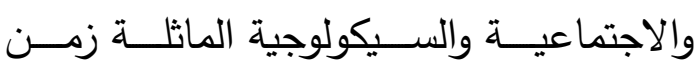
ظهورهـا، أم أنها تظل سـجينة تلك الشـروط؟ ..." حسـين علي، العلـم والأيـديولوجيا بـين الإطــلاق والنســبية. (دار التــوير للطباعـة والنشر ، بيروت، 2011م) ص. 37. 36- ستانلي فش، هـل يوجــ نس في هـا الفصل؟ سـلطة الجماعـات المفسـرة. ترجمـة: أحمـد الثـيمي. (المجلـس الأعلـى للثقافـة،
العربية باتجاه المنطق، يقول ابن خلدون عن أهل المغرب وأفريقية: "... فأصبحت صناعة العربية عندهم كأنها من جملة قوانين المنطق العقليـة والجدل، وبعُدت عـن منـاحي اللسـان وملكته ..." (ابن خلدون: المقدمة. ج3، ص.

28- يقول طـه عبد الرحمن: "لا يصـح تقويم إنتاج أحد علماء المسلمين أو أحد حكمائهم ما

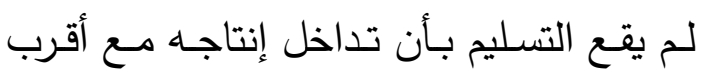
العلـوم إلـى مجـال التـداول الإســلامي العربـي

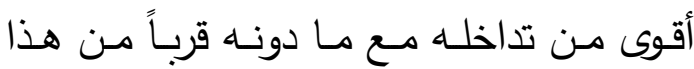
المجال، حتى يقوم الدليل على خلاف ذلك." (طه عبد الرحمن، تجديد المنهج في تقويم التــراث. (المركز الثقـافي العربـي، بيـروت الدار البيضناء، ط2؛ د.ت)، ص. 92.) 29- ــازم القرطـاجني، منهــاج البلغــاء. ص ص. 226، 227.

30- عبد العزيز بومسهولى، 》أسس ميتافيزيقا البلاغة: تقويض البلاغة،ه مجلة فكر ونقد. (دار النشـر المغربيـة، الـدار البيضــاء، س33، ع25، يناير 2000م)، ص. 113. 31- يـرى ابن خلدون أن الأنظـار في العلـوم العقليـة، خلافـاً للعلـوم الثـرعية، يُطلـب في كي صـحتها مطابقتها لمـا في الخـارج، وإن كـان العلماء في جميع العلوم يقومون بتجريد أمور كلية عامـة يقيسون على أشباهها وأمثالها مـا هو فروع: المقدمة. ج2، ص. 227. 32- عبد العزيز بومسهولى، 》أسس ميتافيزيقا البلاغة ...6، ص. 112. 
ومناقثـات. (مركز دراسـات الوحدة العربيـة،

بيروت، ط1؛ يوليو 1991م)، ص. 47.

40- كحمد العــري، البلاغــة العربيـة: أصــولها وامتداداتها. ص.

41- عحمد الناصــر العجيمـي، النقــــ العربــي الحديث ومدارس النقد الغربية. (دار تحمد علي الحــامي وكليــة الآداب والعلــوم الإنســانية، صـــفاقس - سوســــة، ط1؛ 1998م)، ص. .456

42- انظـر حـول تحديـد البلاغيـين والعلمــاء العرب للبلاغة في ارتباطها بالقرآن وإعجازه: - الســكاكي، مفتــاح العلــوم. ص. 162، ص. 415 وما بعدها.

- الخطيب القزويني (ت 739هـ): الإيضـاح في علوم البلاغة. شرح وتعليق وتنقيح: ححمد عبد المـنعم خفـاجي. (دار الجيـل، بيـروت، ط3؛ 1993م)، مج1، ج1، ص. ص. 46 وما بعدها. - أبـو هــلال العسـكري (ت 395هـ)، كتــاب الصناعتين: الكتابة والشعر. تحقيق: علي محم البجاوي وحمد أبو الفضل إبراهيم. (دار الفكر العربي، القاهرة، ط2؛ 1971م)، ص. 7 ومـا بعدها. - ابن خلدون، المقدمة. ج3، ص. 247. 43- ابــن البنــاء المراكثــي (ت 724هــــ، الروض المربـع في صناعة البديع. تحقيق: رضوان بنشقرون. (دار النشر المغربية، الدار البيضاء، ط1؛ 1985 م)، ص. 68. 44- راجـع فـي فضــل البيـان: أبــو القاســم الكُلاعـــي الأشــبيلي (ت مــــا بـين 545-
القاهرة، 2004م)، ص. 376.

37- باتريك هيلي، صور المعرفة. ص. 17. 38- عمارة ناصر ، الفلسفة والبلاغة - مقاربة حجاجيــة للخطـــاب الفلســفي. (منشـورات

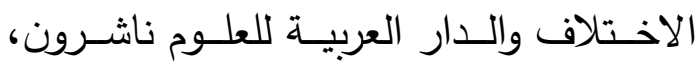
الجزائر - بيروت، ط1؛ 2009م). ص. 11. 39- تحمد عابد الجابري، نحن والتراث: قراءات معاصرة في تراثنا الفلسفي. (المركز الثقافي العربــي، بيـروت - الــدار البيضـــاء، ط6؛ 1993م)، ص ص. 11، 12. كمــا يصــف الجابري الفهم الذي يأخذ أقوال الأقدمين كما هـي، والــذي يتميـز منهجـــه بالاستتســاخ والانخـراط في إثـكاليات المقروء والاستسـلام لها؛ ويعاني من: غياب الروح النقدية، وفقدان النظرة التاريخية؛ هذا الفهم أو المنهج يسميه الجابري 》الفهح التراثي للتراث《 حيث 》التراث يكرر نفسـهـ. ومـن أجل تجـاوز هذا الفهم/ المنهج يدعو الجابري إلى التعامل مع التراث

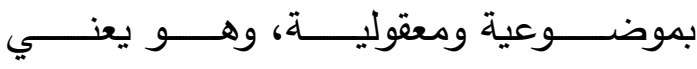
بـاالموضوعية) جعل التراث معاصراً لنفسـه، وإعادة التاريخية إليه، بالكثف عن مضـمونها الأيديولوجي، الثيء الذي يقضي فصله عنا؛ ويعنـي بـ》المعقوليـة 《علـه معاصـراً لنـا، أي إعادة وصله بنا. راجع فيما سبق:

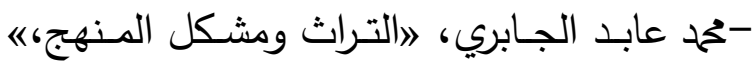
ضـمن كتاب: المنهجيـة فـي الأدب والعلـوم

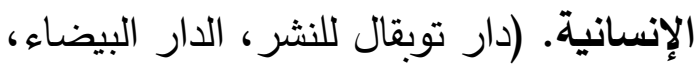
ط3؛ - محمد عابـ الجـابري، التـراث والحداثـة: دراسـات 


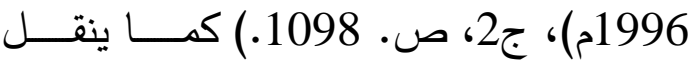
القنّوجي بعض كلام الجرجاني، مشيراً إلى أن أن

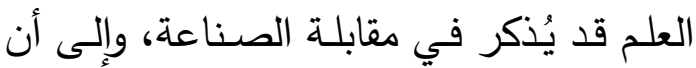
القول بأن العلم أو ملكة الإدراك يتناول العلوم

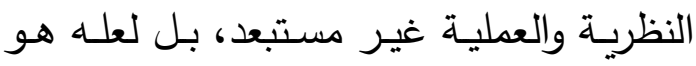
المناسب للعرف: (القنّوجي، أبجد العلوم: 1الوشي المرقوم في بيان أحوال العلوم. ص. 13.) ويذكر جميل صليبا، من بين معاني متعددة للصناعة، أنها مجموع الطرق المنظمة ولئة أو القواعد المبنية على المعرفة العلمية، والتي لفي

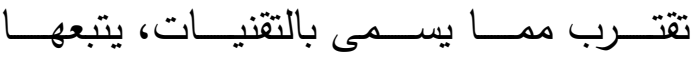
المختصــون، وتقــوم علـى تطبيـق الحقــائق

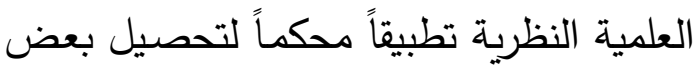

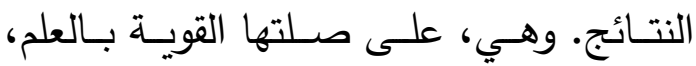
تفترق عنـه، خيث تكون غايـة العلم معرفـة

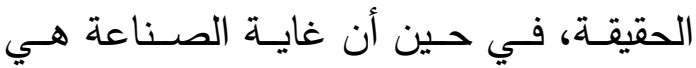
الإنتاج، فالعلم نظري، والصناعة عملية، وإن فئل

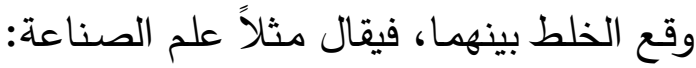
(جميل صليبا، المجم الفلسفي. (دار الكتاب

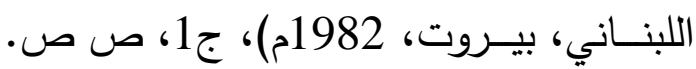
734-737.7 ويقول جابر عصفور : "... قد صدا. ينصــرف مفهـوم 》الصـــاعةه إلـى الجوانـب العملية المتعقة بكيفية العمل، بينما ينصرف مفهوم 》العلمه إلى الأصول النظرية المتعلقة بإدراك الكليات، وبالتالي يرتبط العلم بالإدراك الك الك

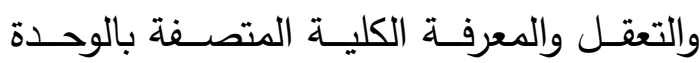
والتعميم، كما ترتبط الصناعة بالقواعد العملية

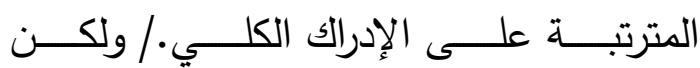
المصطلحين - رغم هذا التقابل - يتداخلان الاندان
550هـ)، إحكام صنعة الكلام في فنون النثر ومذاهبه في المشرق والأندلس. تحقيق: محمد رضـوان الدايـة. (عـالم الكتب، بيـروت، ط2؛

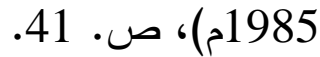
45- ابـن البنــاء المراكثــي، الـروض المريـعـ. ص. 46- انظر محاولة ابن البناء التفريق بين العلم والصـناعة، ومـن ثم التفريق بين علم البيـان وصناعة البديع أو صناعة البيان ومـا يدخل فيهــا مـن الفصـاحة والبلاغــة: ابـن البنـــاء المراكثـي، الـروض المريـع. ص ص. 87-

47- يـرى السيد الجرجـاني أن الصـناعة هـي

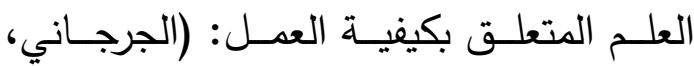
التعريفات. ص. 152.) ويذكر التهانوي، بعد

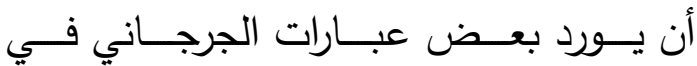

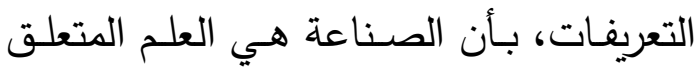

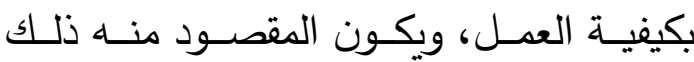
العمل، سواء حصل بمزاولة العمل كالخياطـة

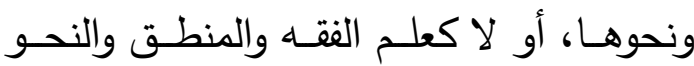
والحكمة العملية ونحوها مما لا حاجة في إلى الى مزاولـة الأعمـال. وقد تُعسر بملكسة يقتدر بها لها على استعمال موضوعات ما لنحو غرض من لن

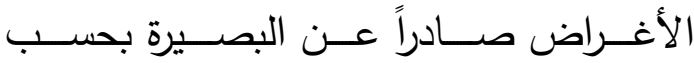
الإمكان، والمراد بالموضوعات آلات يتصرف

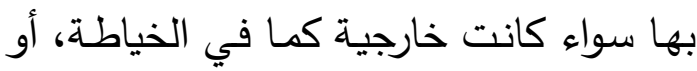
ذهنية كما في الاستدلال: (محمد علي التهانوي، كثـاف اصطلاحات الفنـون. تحقيق د. على الاسل دحروج. (مكتبة لبنان ناشرون، بيروت، ط1؛ 
133. وانظر في قول حازم القرطاجني بأن مرقاة البلاغة لمن رامها وطمح إليها هي تلك لك المعضــودة بالأصــول المنطقيــة والحكميــة:

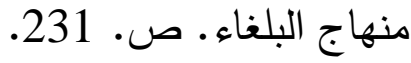
52- يرى الثاطبي أن أصول الفقه في الدين

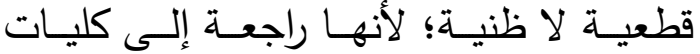
الشريعة، فهي مبنية إمـا على أصـول عقلية،

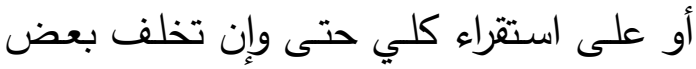
الجزئيات عن مقتضى الكلي الذي ثبت، إذ لا لا يخرجه عن كونـه كلياً. وهو يعني بالكليات:

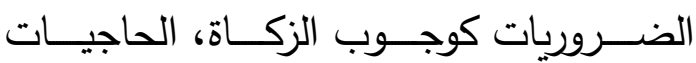
كالقصـر في الصـلاة، التحسينيات كالطهـارة التي شرعت للنظافة. إن الثاطبي - كما يقول

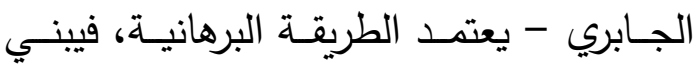

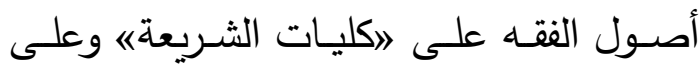
"هفاصد الثرع《، حيث تقوم كليات الثريعة

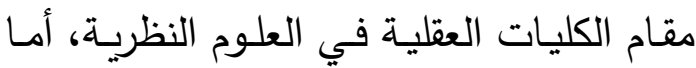
مقاصـــ الشـرع فهـي السـبب الغـائي النـاظم للمعقولية، وطريقه إلى هذه الكليات هو نفس الطريق إلى الكليات العلميـة: إنـه الاستقراء، استقراء جزئيات الشرع، واستخلاص الكليات منها. وستكون هذه الكليات، بطبيعة الحال،

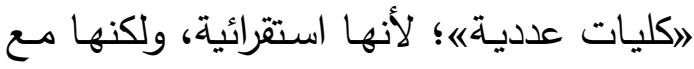

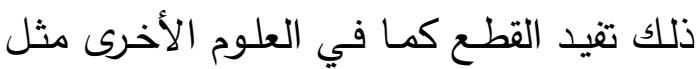

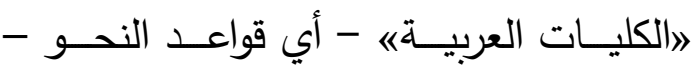
والكليات في العلوم المشابهة التي تستخلص الترات

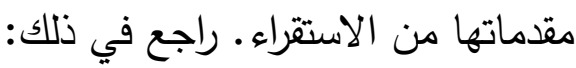

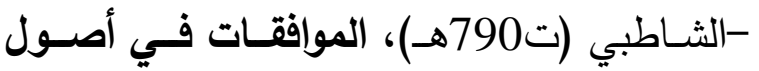

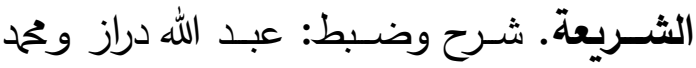

غير مرة في الاستخدام القديم؛ فيطلق 》العلمه على إدراك المسـائل وعلى المسـائل نفسـها، المها، وعلى الملكة الحاصلة عن هذا الإدراك، كما الكاليا يوصف الاقتدار على استعمال الموضوعات بأنه 》علم) و "صناعة) و "صنعة) في آن؛ ولذلك يقول التهانوي: اروقد يذكر العلم في مقابلة الصناعة، [وقد] يعم إطلاقه على ملكة

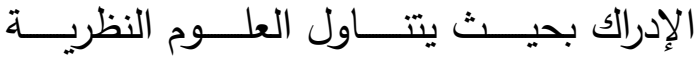
والعملية.، ... وعلى مستوى التعميم يترادف مصـطلح "صــاعة البلاغـةه مـع مصـطلح "علم البلاغةه ..." (جابر عصفور ، مفهوم الثــر : دراسـة فـي التـراث النقـــي. (دار

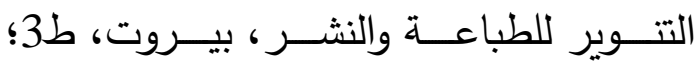
1983م)، ص ص. 129، 130.)

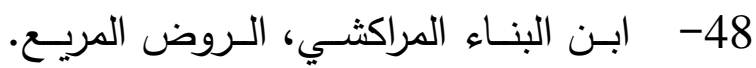
ص. 174.

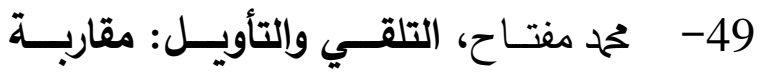
نسـقية. (المركز الثقافي العربي، بيروت الـــدار البيضـــاء، ط1؛ 1994م)، ص. 45. وانظر أقسـام الكـلام أو المخاطبات عند ابن البنـاء المراكثـي: الـروض المريـع. ص ص. $.82 ، 81$

50- يقول الفارابي: "والقوانين في كل صناعة أقاويل كلية، أي جامعة. ينحصر في كل واحد

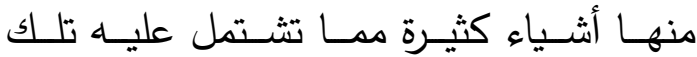
الصناعة، حتى يأتي على جميع الأثشياء التي

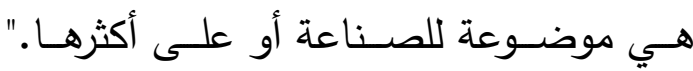

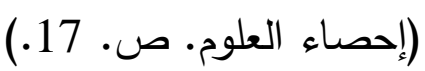
51- جـابر عصـفور، مفهـوم الثــعر. ص. 
حمح العمري، اتخليص الكليات في قراءة فن

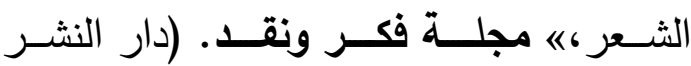
المغربيـة، الــدار البيضــاء، س1، 1، عه، أبريـل 1998م)، ص ص. 101-115. 57- يعلن الفارابي في مقالته في قوانين الشعر أنه لا يقصد إلى استيفاء جميع ما يُحتاج إليه في هذه الصناعة؛ لأن الحكيم أرسطو نفسه لم يكمـل القـول في ذلكـ، إذ لـم تتقدمسه أصـول وقوانين يبني عليها، وهو (أي الفارابي) بدوره لن يسعى لذلك، يقول: "... ولو رمنـا إتمـام/

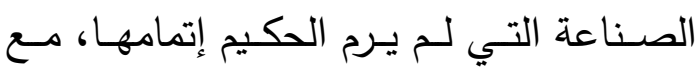
فضـله وبراعته، لكـان ذلك ممـا لا يليق بنـا. فـالأولى بنـا أن نـومئ إلـى مـا يحضـــــا مـن القوانين والأمثلة والأقاويل التي يُنتفع بها في هذه الصـناعة.": 》مقالـة في قوانين صـناعة الشعراء، « ص ص. 149، 150.

58- لعباس أرحيلة مقال بهذا العنوان: عباس أرحيــة، 》ابـن البنـاء والبحــث عـن كليـات

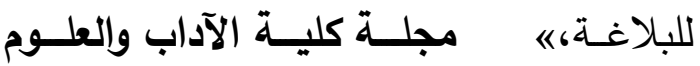
الإنسانية. (جامعة القاضي عياض، مراكش، ع8، 1992م)، ص ص. (254-262. 59- يرى ابن البناء: "إن استكمال الإنسان في

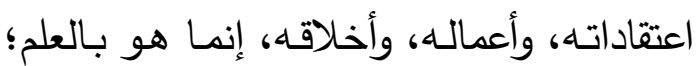

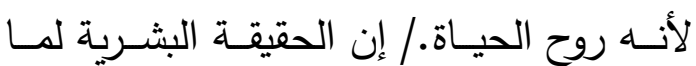
كانــت قاصــرة عـن الكمـال، احتاجـــ إلـى لـ لـ الاستكمال = \}وقل ربي زدني علماً]" (اشرح رسالة الكليات،ه ضمن كتاب: من تراث ابن البنــاء المراكثــي. تحقيـق: عمـر أوكـان. (أفريقيا الشرق، الدار البيضاء، 1995م)، ص
عبــــ الله دراز • (المطبعــة التجاريــة الكبـرى، القــــــاهرة، د.ت)، ج1، ص ص. 19 19، 20؛

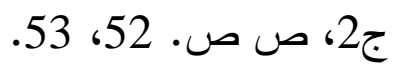
- محمد عابــــ الجـابري، التـراث والحداثــة. ص. .210 53- محم عابد الجابري، التراث والحداثة. ص. 215. ويمكن الرجـوع بالتفصـيل إلى تحليـل الجــابري للنزعـــة البرهانيــة فـــي المغــرب والأندلس. ص ص. 201-215. 54- أبو نصـر الفـارابي (ت 339هـ)، 》مقالـة في قوانين صـناعة الثـعراء،ه ضــن كتاب: أرسـطوطاليس، فـن الثــعر : مــع الترجمــة العربية القديمـة وشـروح الفـاربي وابـن سـينا وابن رشد. ترجمة وشرح وتحقيق: عبد الرحمن بدوي. (دار الثقافة، بيروت، د.ت)، ص ص. .158-149

55- ابن سينا (ت 427هـ)، 》افن الثـعر من كتاب الثـفاء،" ضــن كتـاب: أرسـو، فـن الثعر • ص ص. 167-171. 56- ابن رشـ (ت 595هـ)، (اتلخيص كتاب أرسطو طـاليس في الثـعر ، « ضــن كتـاب: أرسطو، فن الثـعر • ص. 250. ويكرر ابـن رشــ أكثر مـن مـرة (ص ص. 201، 207، 250) بـأن مـا ذكـره أرسـطو في كتابـه فـن الشعر من الأقاويل المشتركة لجميع أصناف الشعر هو من الأمور المشتركة لجميع الأمم

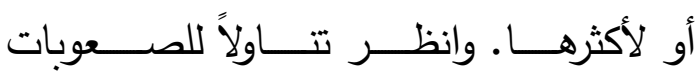
والإجراءات المتعلقة بقراءة ابن رشد وغيره من الفلاسفة المسـمين لفن الثـعر لأرسطو في: 
64- يحدد ابن البناء صناعة البديع بأنها "...

ترجع إلى صناعة القول ودلالته على المعنى

المقصـود ..." (الـروض المريـع. ص. 8. 8. .)؛

أمــا البلاغـة عنده فهـي: ".. أن يُعبَّرَ عـن

المعنى المطلوب عبارة يسهل بها حصوله في

الـنفس متمكنــاً مـن الغـرض المقصــود ..."

$$
\text { (الروض المريع. ص. مV.AV.) }
$$

65- ابـن البنـاء المراكثـي، الـروض المريـع.

$$
\text { ص. }
$$

66- انظر حول اعتبارات تقسيم اللفظ والمعنى

عنــــــن البنـاء المراكثـي، وعنـــ غيـره مـن المناطقــة والأصــوليين والفلاسـفة والبلاغيـين

أمثال: ابن سينا، الغزالي (ت 505هـ)، الرازي (ت 606هـ)، السـكاكي، حسازم القرطـاجني، السجلماسي (ت 730هـ): ابن البناء، الروض المريــع. ص ص. 75-78. ســارة مجـدي،

$$
\text { المصطلح البلاغي. ص ص. 37-44. }
$$

67- يتحدث هيلمسليف L. Hjelmslev عن expression مستوين لسانيين هما: التعبير والمحتوى content، مأخوذين من نموذج دي سوسير Ferdinand de Saussure: الدال signifier والمـدلول signified، واللـذين لا يتحقـق تفـاهم بـدونهما؛ مـع إضــافة عنصـريّ المـادة form formstance والثـكل منهما، بحيث يكون لكل من التعبير والمحتوى مادة وشكل، فتكون المحصلة نسقاً مكوناً من أربعـة أبعـاد لكل منهـا دلالته المحتملـة: مـادة التعبير وشكله، ومادة المحتوى وشكله؛ تفادياً لتمايز الشكل واستقلاله عن المحتوى، والتباس
ص. 29، 30. ) ثـم يتــابع ابـن البنـاء فـي رسـالته (ص ص. 29-70) شـرح الأمسـور الكلية التي تُستكمل بها الحقيقة البشرية، وتُعد ضوابط للنظر في مراتب الإدراك البشري. 60- ابن البناء المراكثي، الروض المريع. ص ص. 68، 69. ويشـير تحمد مفتــاح إلـى أن أن

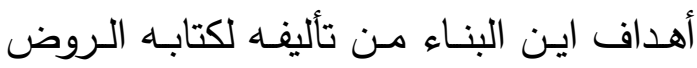
المريـع "... تتضـافر لصـياغة قوانين تأويليـة تعصـم من القول في كتاب الله وسنة رسوله

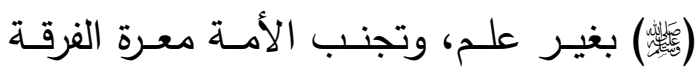

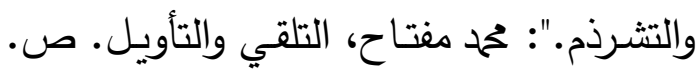

61- ابـن البنـاء المراكثـي، الـروض المريـع. ص. 173. وانظـر عبـارة ابـن رشـــ حــول

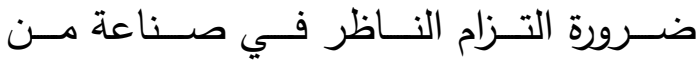
الصناعات لمبادئها، دون نفي لها أو إبطال: ابـن رشــ (ت 595هـ)، تهافــت التهافــ. تحقيق: سليمان دنيا. (دار المعارف، القاهرة، ط3؛ 1981م)، القسم الثاني، ص. 791.

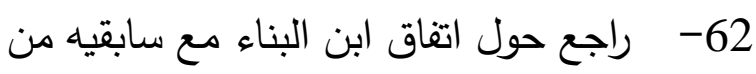
البلاغيـين فـي كثيـر مسن الثــواهد والصــور الجزئية والمفاهيم: ححمد مفتاح، التلقي والتأويل. ص. 43 وما بعدها؛ سارة مجدي، المصطلح البلاغـي فـي كتــاب: الـروض المربــع فـي صناعة البديع لابن البناء المراكثي. (رسالة ماجسـتير مخطوطــة، كليــة الآداب، جامعــة الزقـازيق، 2015م)، ص. 78 ومــا بعـدها،

$$
\text { ص. } 134 \text { وما بعدها. }
$$

63- محد مفتاح، التلقي والتأويل. ص. 57. 
الــدار البيضـــاء، 1986م)، ص ص. 135، .140

وحـول المقصـود بالأبنيـة العليـا والأبنيـة الدلاليـة الكبـرى للــص، وكيـف أن الأولـى تتصـل بشـكله، بينمـا تتصـل الثانيـة بمضـــــــه، وإن كان المعول في المفهومين هو اعتبار النص

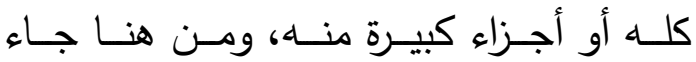
وصفهما بالشمولية، غير أن مقولات ابن البناء

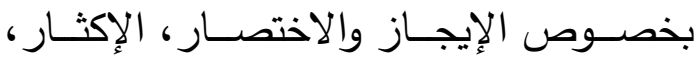
التكرير قابلـة للتوسيع والامتداد، بحيث ينتقل

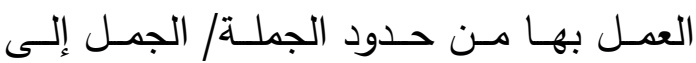
النص، ذلك الانتقال الذي لم يتم الاشتغال بـ إلا مـع تطور المعرفة اللسانية والنقدية؛ حول مــا سـبق انظـــر : صــلاح فضــل، بلاغــة الخطاب. ص. 221 وما بعدها.

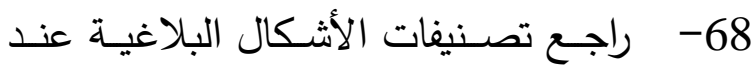
بيريلمـان، وجماعـة مـو، وفـان دايك: صـلاح فضــلـ، بلاغـــة الخطـــاب. ص ص. 203،

$$
207 \text { وما بعدها. }
$$

69- ابـن البنـاء، الروض المريـع. ص. 106. وانظر الإبدال في الاستعارة: ص. 115.

70- ابن البناء، الروض المريع. ص. 115. 71- انظر في احتمالات الحذف في الإبدال: ابـن البنـاء، الـروض المريـع. ص. 143 ومـا

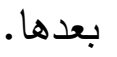

72- محمد مفتاح، التلقي والتأويل. ص. صن 51. 73- عــالم الســيميولاكر simulacre عـالم يحكمه الاستنساخ والعود الأبدي، لا وجود فيه للشيء إلا في عودته، من حيث هو نسخة من
المحتـوى بـالمعنى، واعتبـار الشـكل في ذاتـه فارغاً من المعنى، وإمكانية استخلاص المعنى مـن دون سـيرورة تفسيرية فاعلـة. فالجانـبـ الصـوتي الفيزيقي من اللغـة هو مـادة التعبير المشـتركة في كل اللغـات الطبيعيـة، والطـرق الخاصة لانتظامها وتثكلها واستعمالها في كل لغة هي شكل التعبير ؛ أمـا الواقع المعيش في ذاتـه: الأشـياء، البشـر ، الموضـوعات، مجمـل العالم الخارجي فهو مادة المحتوى، في حين أن تصـور هـذا الواقـع يمثل شكل المحتـوى. وبنـاء على ذلك تكون العلامـة اللغويـة هـي الوحـدة المتثـكلة مـن شـكل التعبير وشـكل المحتوى، وتكون العلاقة بينهما هي ما تحدد دلالـة العلامـة ووظيفتهـا. ففي حالـة الدلالـة الوضــعية تكـــون المطابقـــة بــين التعبيــر والمحتوى، أما الدلالة غير الوضعية فهي التي تتحقق من خـلال نظام من الدوال والمدلولات المتعاضدة، يتكون صعيده أو مستواه التعبيري من علامات النظام الوضعي الأول، في حين يتجلى محتواه في الأيديولوجيا العامـة المتثربة للثقافـة والمعرفـة والتـاريخ. راجـع حـول نظريـة اللغة والعلامة عند هيلمسليف: - لويس هيلمسليف، حول مبادئ نظريـة اللغـة. ترجمة: جمال بلعربي. (دار الأمان ومنشورات الاخــتلاف ومنشــورات ضــفاف، الربــاط الجزائر - بيروت، ط1؛ 2018م). ص ص. $.138-125$ ، 72-58 - رولان بارت، مبادئ في علـم الأدلـة. ترجمـة: محمد البكـري. (دار قرطبـة للطباعـة والنشــر ، 
الكبيــر الثــرقاوي، 》هقدمــة ...6، كتــاب:

البلاغة القديمة لرولان بارت. ص ص. 18-

20. وعن المصـير الذي آلت إليـه البلاغـة صلانس

خلال العشرين قرناً، يقول تودوروف وديكرو:

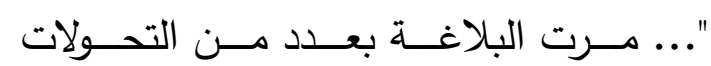

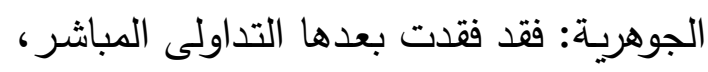

ولم تعد تعليماً للإقناع بقدر ما أصبحت تدريباً

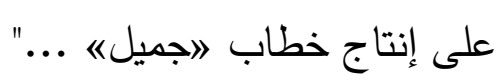

Ducrot, Oswald and Todorov,

Tzvetan (1979), Encyclopedia

Dictionary of the Sciences of

Language. Trans. Catherine

Porter. (Johns Hopkins Unversity

Press, Baltimore-London, 1994), p. 74 .

75- عبد العزيز بومسهولى، 》أسس ميتافيزيقا

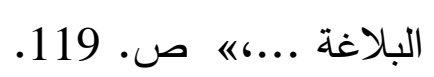

76 - معـارة ناصـر، الفلسـفة والبلاغـة. ص. ص. 00. ويحدد ريكور الفهم في تميزه عن التفسير أو الثرح بأن التقسير هو تعيين شروط ظاهرة

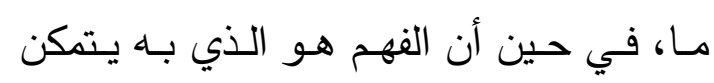

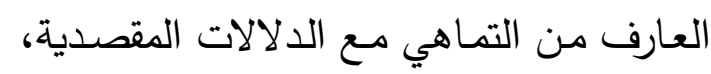

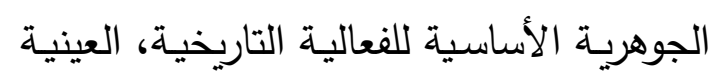

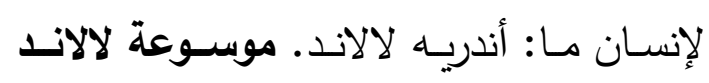

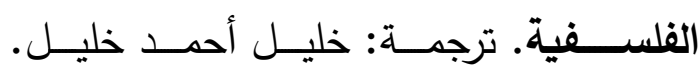

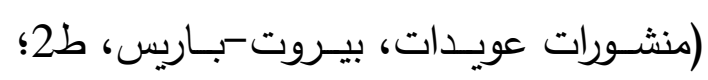
2001م)، مج1، ص. صولـ 193.

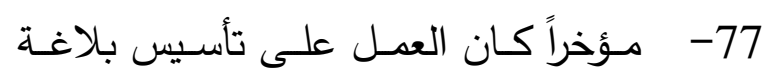

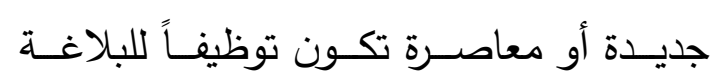

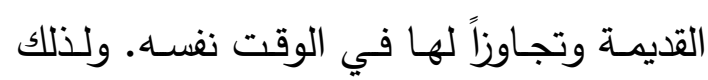

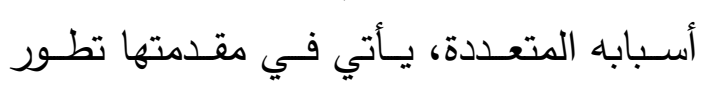

نستخ لا متتاهية، ولكنها نسخة لا أصل لها،

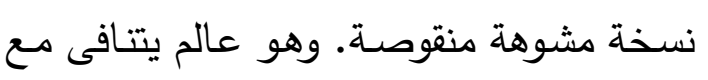

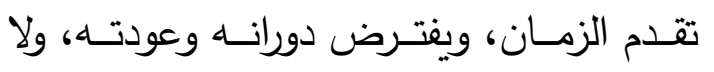
وجود فيه للثيء إلا في عودته، ولا حضور

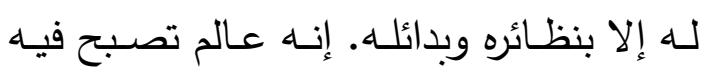
الهوية تكراراً، تتصدع فيه الذات، وتنهار فيه

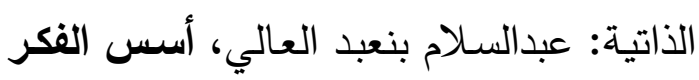
الفلسفي المعاصر. مجاوزة الميتافيزيقيا. (دار

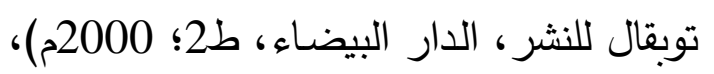
ص ص. 103-105. توبعال

Chaim Perelman (1977), The -74

Realm of Rhetoric. trans. William Kluback. (University of Notre Dame Press, Notre Dame, 2008), ومن الجدير بالذكر أنه مع تدهور p. 152.

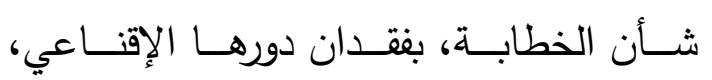
والذهاب بتنوع مقاماتها، انحسرت البلاغة في

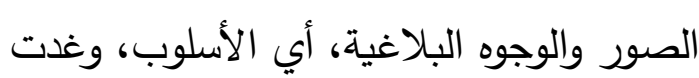

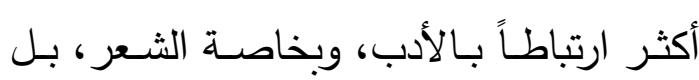

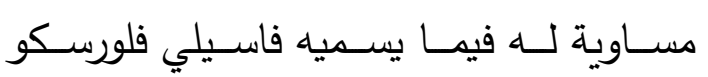
بـأدبنـة البلاغة 《) literaturization of

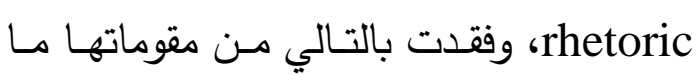
كـان يجعلهـا بلاغــة عامــة، وصـارت علمـاً للفصـاحة أو المحسـنات والصــور، أو مجـرد نظريـة في الاستعارة بوصفها النموذج الأمثل للانزيـاح الذي يمثل جوهر الوجوه البلاغيـة.

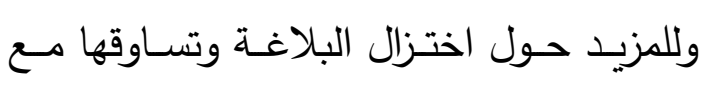
الأدب، زمن تراجع مكانة الخطابة في الحياة

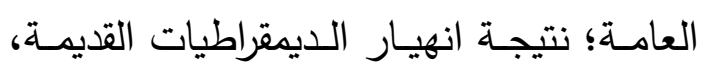

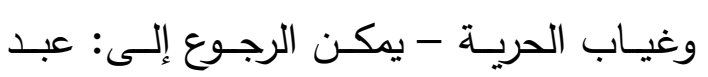


والمعاصـر : صـراع طبقي أم مشكل ثقـافي،ه ضــن كتاب: التـراث وتحـديات العصـر في الـوطن العربـي: الأصـالة والمعاصـرة. (مركز دراسـات الوحدة العربيـة، بيروت، ط2؛ يونيو 1987م)، ص. 49 80- محمد عابـد الجـابري، إإشـكالية الأصـالة والمعاصرة ..6، ص. 47. 81- حمد بنيس، مساءلة الحداثة. ص. 6. 82- يتحدث لوتمـان عما يسميه اخلق سلوك مستقبلي مغاير للتراث«، وهو ما يتحقق عندما يدخل الإنسـان في نطاق ثقافة ولغـة سـابقتين على وجوده، فينفعل بهما، فتؤثران فيـه، كما يؤثر هو بدوره فيهما ويغيرهما. في مثل هذا المجال يقوم صراع بين ثقافات التغيير وسلوك الإنسـان الذي يحاول تغييرهـا رغم مقاومتهـا. انظر في ذلك: أمينـة رشيد، 》السيميوطيقا في الـوعي المعرفي المعاصـر ،ه ضــمن كتـاب: أنظمـة العلامـات في اللغـة والأدب والثقافـة: مدخل إلى السـيميوطيقا. إشراف: سيزا قاسم ونصر حامد أبو زيد. (دار إلياس العصـرية، القـاهرة، 1986م)، ص. 61. ويمكـن النظـر

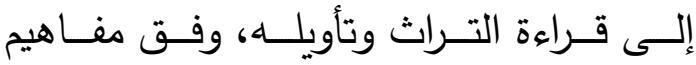
كانغيلام، على أنها تنقيح للمعرفة، والذي هو كما يرى تنقيح استردادي يكون من شأنه إعادة تتظيم للمعرفـة، انطلاقـاً مـن قواعدها ذاتهـا، على نحو يلغي تاريخيتها: جورج كانغيلام، دراسـات فـي تــاريخ العلـوم وفلسـفتها. ص.
المعرفـة اللسـانية، لاسـيما فيمـا يتعلق بتأكيد النظــر إلــى اللغـــة بوصــفها أداة للتواصــل الإنساني. والذي يشكل جوهر البلاغة. وكذلك تزايد الاهتمام بالخطاب بوصفه كلاً، وتحليل وحداتـه، مـن جانـب نظريـات تحليـل الخطـاب والسـيميائيات، وهـي اهتمامسـات وانشــالات كانــت تمثـل مجــال عمـل البلاغــة القديمــة وتصــنيفاتها. وكـذلك أيضــا تطــور النظريــة النقدية المواكب لتطور الأشكال الأدبية، ومـا تطرحه من إشكاليات متجددة، وشروط قرائية خاصــة، ومـا صــاحبها مـن مفـاهيم الكتابـة والنص وغيرهـا مدـا يتعلق بـالوعي الجمـالي للغة، في مقابل تباين المواقف حول الوظائف الأيديولوجيـة والاجتماعيـة للغـة الأدب. راجـع فيما سبق: هنرى بليث، البلاغة والأسلوبية ـ نحو نموذج سيميائي لتحليل النص. ترجمة: محمد العمـري. (منشـورات دراسـات سـال، الـدار كء، ط1؛ 1989م)، ص. صن. 15 البيض ومابعدها.

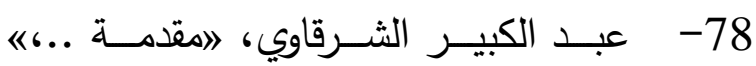
كتــاب: البلاغــة القديمـة. ص. 18. ومــن المنظور ذاتـه، يـرى صسلاح فضـل أن الجهـد البلاغي الحديث لا ينبغي مطلقـاً أن يختلط بالرغبة الوهمية في إحياء البلاغة القديمة. فلم

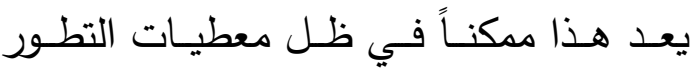
العلمـي والحضــاري: صــلاح فضــل، بلاغــة

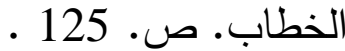

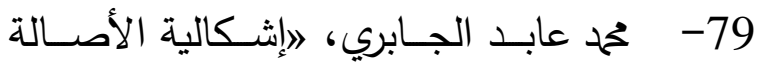
والمعاصــرة فـي الفكــر العربــي الحــديث 
على الرغم مـن أن مستوى الدراسـات اللغويـة الحديثـة فـي العـالم العربـي يـؤذن بإمكانيـة احتضان علم الأسلوب، ذلك أن علم الأسلوب الحديث يرجع، فيما يذكر صـلاح فضل، إلى أبوين همـا: اللسـانيات الحديثة، وعلم الجمال الفلسـفي: صــلاح فضـل، عـــم الأسـلوب. ص.3. وما بعدها.

89- في بحثه في الثعر العربي الحديث، يعلن حمح بنـيس تبنيـه "... إحـلال فرضـية الإبـدال

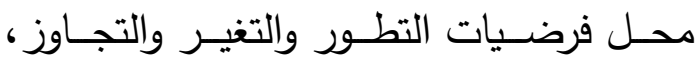
حيث/لا يكون الانتقال قطيعة مـع الماضـي، ولا إقامـة شـقية فيـه، بـل هـو عـودة حيويـة لا لاكل نهائيـة لماضـي الكتابـة وحاضـرها، مـن خـلال تجربة الذات واختراقها هي وتاريخها للغة. هذا

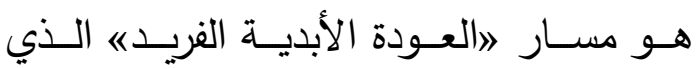

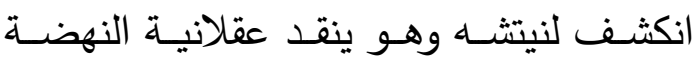
والقـرن الثامن والتاسـع عشر ... اهـا الـذي سيفيدنا فعلاً إذا نحن قلنا إن فكرة سبق لها أن وجدت مثلاً لدى ليبنيتز ، أو حتى أفلاطون؟ لأي شـيء تتفـع هـذه الإشـارة إن هـي كانـــ

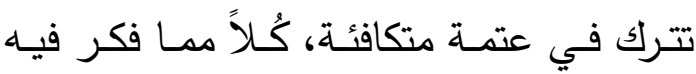

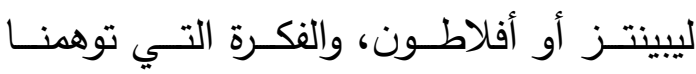
توضـيحها عـن طريـق مثـل هـذه الإحـالات التاريخيـةهـ. فهي لـى نيتشـه لا تعنـي عـودة الثيء ذاته، ولا عودة إليه، كما يرى دولوز ،

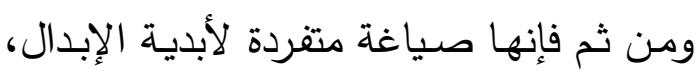
ولأبديـة اختراق الذات للغــة ...": محمد بنيس، مساءلة الحداثة. ص ص. 171، 172، 172. 90- شكري عياد، (اللغـة والإبـداع - مبادئ
ترجمـة: عـادل العـوا. (المؤسســة الجامعيـة للدراســات والنشـر والتوزيــع، بيـروت، طب؛ س 9 (م)، ص ص. ص. 37، 70. 84- رولان بارت، قراءة جديدة للبلاغة القديمة. ص. 85- لم تكن الحداثة اختياراً ولا نتاجاً ذاتياً من داخل الـوعي العربـي؛ ومـن ثم فـإن الدخول إليهـا، مـن غيـر تبعيـة او اسـتلاب للغـرب، يستدعي استنباتها في تربتنا الثقافية، بقراءتها في تاريخيتهـا وفهم مقولاتهـا ومفاهيمهـا في نسبيتها؛ وبالتعرف على أسس تقدمها، وهي بصفة خاصـة العقلانيـة والروح النقديـة. وفي هذا السـياق يـرى حمـادي الرديسي أن العـالم

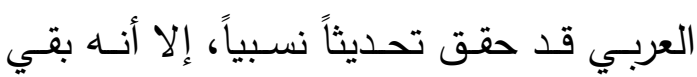
ثقافياً شبه حديث، وسياسياً تسلطياً. انظر فيما سبق: -خحم عابد الجابري، "إشكالية الأصسالة والمعاصرة .

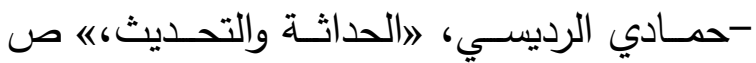

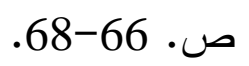
86- محمد عابــد الجـابري، إإثــكالية الأصـالة والمعاصرة ...6، ص. ص. 47. 87- محم عابد الجابري، التراث والحداثة. ص. .38

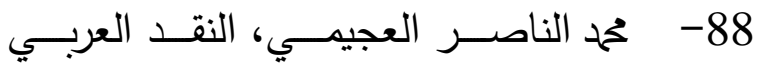
الحديث ومـدارس النقـــ الغربيـة. ص. 147. ويضيف صلاح فضل إلى الأسباب التي تقف

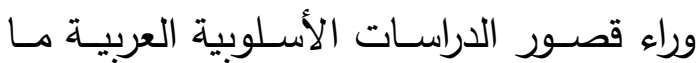
تعانيه البيئة العربية من قحط فلسفي جمالي، 
تركيـب الجملـة، كحـذف بعـض أجزائهـا، أو تقديم بعض أجزائها على بعض، ويبحث قيمة كل ذلك. ولعلك تلاحظ أننا حين أخذنا في لي تحليـل بعـض نمـاذج مـن اللغــة الثـعريـة ..

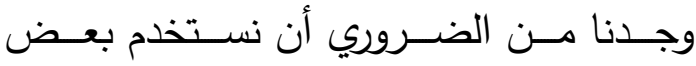
المفــاهيم البلاغيــة. ولا شــك أن دارس علـم الأسلوب في هذا العصر سعيد الحظ جداً، إذ يجد بين يديـه هذه الحصـيلة الوافرة المنظمـة مـن الملاحظــات حــول الألفــاظ والتراكيـبـ ودلالاتهـا التـي تتجـاوز الـدلالات المعجميـة والنحويـة، زلكـن ثـــة فروقـاً مهمــة ينبغـي أن يظل دارس علم الأسلوب على ذكر منها.": شكري عياد، مـدخل إلى علـم الأسـلوب. دار العــوم للطباعـة والنشـر ، الريـاض، 1982م، ص ص. 43، 43، 44). 92- قـدم الـدكتور شـكري عيـاد عـدداً مـن المؤلفــات والدراســات التـي تتصــل مباشــرة بالدرس الأسلوبي، تأليفاً وترجمة، وهي: -مدخل إلى علم الأسلوب. 1982م. - 》قراءة أسلوبية لشعر حـافظ، مجلـة فصـول. (الهيئة المصـرية العامـة للكتاب، القاهرة، مـج 3، ع 2، مــــارس 1983م)، ص ص. 13-

- اللغة والإبداع. 1988م. - „قراءة أسلوبية في كتاب سيبويه،ه ضمن كتاب: قراءة جديدة لتراثنـا النقدي. (النادي الأدبي الثقـــافي، جـــة، 1988م)، ج 2، ص ص. .818-801 - اتجاهـات البحث الأسـلوبي: اختيـار وترجمـة
علم الأسلوب العربي. (إنتز ناشونال للطباعة، القاهرة، ط1؛ 1988م)، ص. 25.

91- في الوقت الذي يضـع فيه شكري عياد -

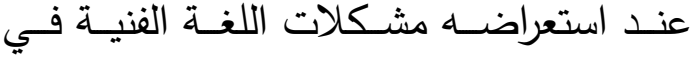
كتابــه: اللغـــة والإبـــداع (1988م) - أقــوال البلاغيـين القـدماء بجانـب أقـوال الأسـلوبيين المعاصرين، لا يفرق بين قديم وحديث، أو بين عربـي وغربـي؛ فهو يقـر، في الكتـاب نفسـهـ

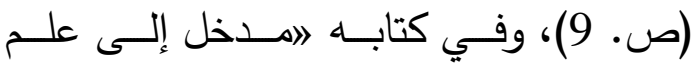
الأسلوبه (1982م)، أن مظاهر التشابه بين علم البلاغة وعلم الأسلوب ينبغي ألا تخفي ما بينهمـا مـن فروق جوهريـة ووجوه اختلاف لا تقـل قيمـة عـن وجـوه الاتفـاق، يقول: "... لا نجد اختلافاً أساسياً بين نظرة علم الأسلوب إلى الموقف، ونظرة علم البلاغة إلى مقتضى الحال ... كل من علم الأسلوب وعلم البلاغة . يفترض أن هناك طرقاً متعددة للتعبير عن من المعنى، وأن القائل يختار أحـد هذه الطـرق؛ لأنه في نظره أكثر مناسبة للموقف. والهدف النهائي لعلم الأسـلوب - كمـا يـراه كثير مـن علمـاء الأسلوب - هو أن يقدم صسورة شـاملة لأنواع المفردات والتراكيب، وما يختص بـه كل منها مـن دلالات. وهذا هو نفسـه مـا يصـفه علـم البلاغـة، فـنحن نعـرف مـثنلاً أن علـم البلاغـة يتتـاول طرقـاً معينــة فـي اسـتعمال المفــردات، كالاســتعارة والمجـــاز المرســلـ والكنايـة، ويبحـث قيمـة كل طريـق مـن هـذه

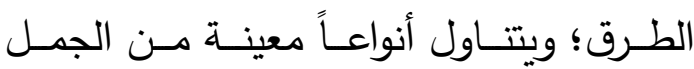
الخبرية/ والجمل الاستفهامية؛ وطرقاً معينة في 
العربية لأن تكون شريكاً فاعلاً في الصياغة العلميـة للدرس النقدي الأسلوبي. وفي سبيل ذلـك ينطلـق مـن صــيغة السـكاكي، ويقـوم بتكميلهـا وإدماجها في المعالجـة اللسـانية الأســلوبية، وتوزيعهــا علــى مســتويات أو مجـالات: أسـلوبيات اللغـة التي تتفرع إلى : الصـــوتيات، الصـــرف، النحـــو (الــنظم)؛ وأســـلـوبيات الأدب: الصـــــــــات الأدبيــــــة (العـروض والقــوافي)، الـنظم الأدبـي (علـــ المعاني، الدلاليات الأدبية (البيان)، التعامليات الأدبيـة (مقتضـى الحـال)؛ وأخيـراً الأسلوبيات المتعينــة أو التطبيقيــة. ويـرى الاســــد أبــو الرضـاه أن النمـوذج اللسـاني الأسـلوبي الذي ولي قدمـهـ مصـلوح لصـيغة السـكاكي بحاجـة إلى

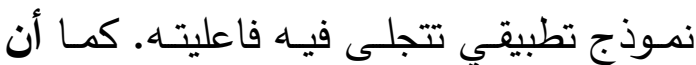
ذوبان البلاغة في الأسلوبية على هذا النحو

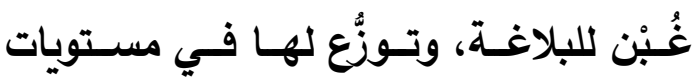
تحليليـة للــص داخـلـل عبــاءة اللســانيات والأسلوبية. ويعلن أبو الرضا قبوله ذلك بشرط أن يكـون تحــت عنــوان الانحليـلـ البلاغـي الأسـلوبي للـصنه، والـذي يتجلى فيـه تـآزر البلاغـة والأسلوبية والنقد الأدبي، ليصبح مـا بين البلاغة والأسلوبية من مباينات واختلافات

ائتلافات معرفية إنسانية. راجع فيما سبق: - سـعد مصـلوح، امشـكل العلاقـة بـين البلاغـة سئة العربية والأسلوبيات اللسـانية،ه ضـمن كتاب: قـراءة جديـدة لتراثنـا النقدي. ج 2، ص ص. ص. .875،867-861، 857 - سعد أبو الرضـا، 》البلاغـة والأسلوبية: ائتلاف
وإضــافة. أصــدقاء الكتـاب للنشـر والتوزيـعـ، القاهرة، ط 3؛ 1999م.

ويمكن مراجعة البيليوجرافيا المستفيضة التي أعدها

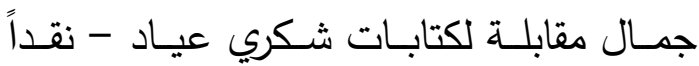
وإبـاعاً وترجمـة وتقديماً ومراجعات ومقابلات وندوات ومقالات في الصحف وأوراقاً لم تنشر - في دراسته: شـكري عيـاد الناقــ. (رسـالة ماجسـتير ، جامعــة اليرمـوك، 1990م)، ص ص. 247-257 - (257.

93- شكري عياد، اللغة والإبداع. ص. 9. 94- راجع حول موقف الغربيين من الربطوريقا

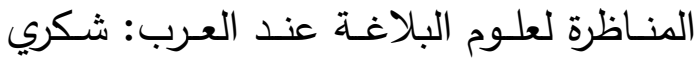
عياد، اللغة والإبداع. ص. 6. 95- راجـع موقـف عبـد السـلام المسـدي مـن علاقة الأسلوبية بالبلاغة القديمة والكلاسيكية، ورفضه أن يكون الحديث عن الأسلوبية وفيها

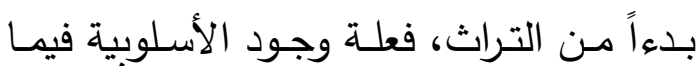
اكتشفته مـن مـنهج جديـد في تــاول الظـاهرة الأدبية، والذي شكَّل قطيعة مع البلاغة: عبد

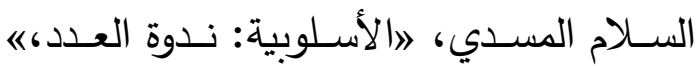
مجلــة فصـــول. (الهيئــة المصـريـة العامــة

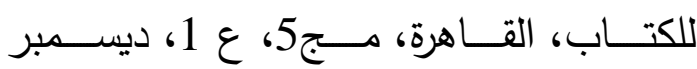
. 1984م)، ص. 216 96- يـرى سـعد مصـلوح أن تجـاوز الأسـباب الموجبـة للمباينـة المعرفيـة بين البلاغـة وبين الأسلوبيات اللسـانية، بإعادة النظر في كثير من أوضـاعها وتصـوراتها وتصـنيفاتها، والذي لا يكـون إلا في حضـور حركـة مواكبـة مـن اللسـانيات العربيـة - هـو مـا يهيـئ البلاغــة 
البلاغـي بعـد مراجعتهـا، وشـرح تحولاتهـا، وإدماجها مـرة أخرى في المنظومـة المنهجيـة للتحليل الأسلوبي. ولا يتردد صـلاح فضل في هـذا السـياق في التأكيـد على أن كثيـراً مـن البحوث التي قدمتها البلاغة للصور والأشكال ما زالت مصدراً ثرياً حياً جديراً بأن يؤخذ في

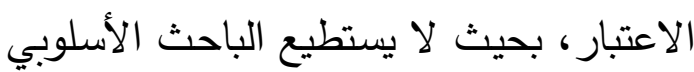
أن يهملها، بل ينبغي عليه تتظيمها وتعميقها في ضـوء مناهجـه الحديثة، وضـمن مجالاتـه البحثيـة خاصــة مـا يتصـل بعلـوم الاتصــال والدعاية والإشهار • وتقف تحليلات ياكوبسون للصــور والأشـكال البلاغيــة وتوظيفهـا فـي التحليل اللساني البنيوي للشعر والأدب بعامـة؛ وإشـارات فـاليري إلـى العـودة الضـرورية إلىى الثــرات المنسـية فـي تحلـيلات الأقـدمين للاســتعمالات اللغويــة الانزياحيــة المســماة بالصــور والأشــكال البلاغيــة؛ تقــف داعمــة للمؤلف في طرحها السابق، وفي إثـارته بعامـة إلـى إمكانيـة الإفـادة مـن الحصــاد البلاغـي والنقـدي القـديم، ومراجعتـه وتمحيصــه، فيمـا

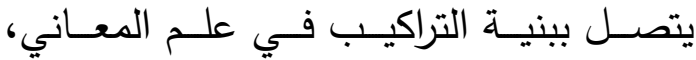
وتحليلات المجاز في علم البيان، والصسياغة في علم البديع، والموازنات بين الشعراء؛ هذا مع عدم الخلط بين هذه البحوث الجزئية التي لا تفقـد ارتباطهـا بتصـورات وقواعد ونمـوذج جمالي عـام أو مثالي وبين البنيـة الكلية لعلم الأسـلوب بمقولاتـه الداخليـة الفرديـة: صــلاح

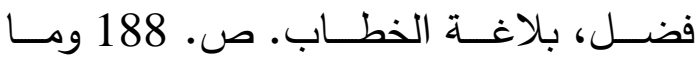
بعدها؛ وكذلك: علم الأسلوب. ص. 136 وما
لا اختلاف، هنمن ندوة: الاراسات البلاغية: الواقع والمأمول. (جامعة الإمام تحمد بن سعود

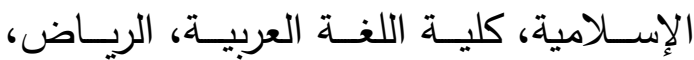

$$
\text { 1432هـ)، ص. } 709 .
$$

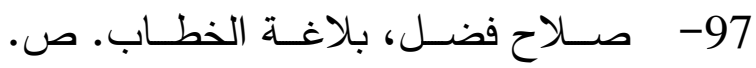

98- يثـير صـلاحح فضـل إلـى إمكانيـة إفـادة

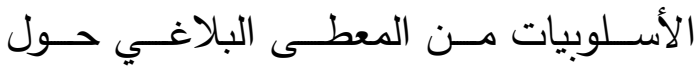
الصـورة، ذلك المفهـوم القـادر على اسـتيعاب كثير من الأنماط التشكيلية البلاغيـة التي لا تعـود فقــ إلـى علاقــات التشــابه والقيـاس والمحاكـاة، بـلـل تضــم أشـكالاً مـن العلاقـات الدلالية، بما فيها الامتدادات فيما وراء اللغـة، أي العلاقات غير اللغويـة. وتأتي هذه الإفادة بعد إعادة النظر إلى أنماط الصورة، وما بينها مـن اختلافـات وفـروق فـي بنيتهـا الثـكلية والدلالية، ومستويات كفاءتها التخييلية، وكثف بـف مصادرها ومنابعها ونماذجها العليا، وعلاقاتها، ووظائفهـا في بنـاء الـنص وتكوينــه وتحديـد خصائصسـه النوعيـة المميزة، أي بـالنظر إليهـا علـى أنهــا نظـام كامـل مـن الأدوات التـي تُسـتخدم لغايـات تأثيريــة وجماليـة وإقناعيـة ضـمن سـياق خـاص ومحدد. ويـدلل صــلاح فضـل على مثل هذا التــاول بمـا ينقلـه عـن لوغـورن مـن أن دراسـة المصـادر ، والأبنيـة، والوظـائف، ومعـدلات التكـرار، والمســاحات الحيويـة الناجمة عن التقاء الأشكال المختلفة، ومسدى تـداخلها وكثافتهـا في الـص - هـي المجـال الأمثل للإفـادة مـن معطيـات البحث 
البلاغـة العربيـة عندما انفصـلت عن التذوق بعدها.

والنقد العملي، وتحولت إلى علم منضسبط لـه 99- يشـير أحمـــ درويسش إلى انقطساع صـلـة قواعده - أصبحت دراسة مهمة تقع في نطاق النقـاد العـرب المحـدثين بـالتراث البلاغـي، ما يُعرف في اللسانيات الحديثة بالأسلوبيات. وفي سياق تأكيد التقارب والتتاظر بين البلاغة العربيـة والأسـلوبية الحديثـة يرصـد عدد مـن النقـاد والدارسـين بعضــاً مـن التشـابهات بـين المفـاهيم البلاغيـة والمقولات الأسـوبية. ومـن هـذه المفـاهيم والمقـولات: مقتضـى الحـال أو المقــام فـي مقابـل الموقـف Situation أو السـياق Context، فمراعـاة مطابقـة الكـلام لمقتضـى الحـال التـي هـي شـرط للبلاغــة، والحديث عن دواعي الحذف والذكر ، والتقديم والتأخير ... إلخ - يمكن تتاوله مع ما جاءت به الأسلوبية من عناية بدور السياق وعناصر التواصل اللغوي في تشكيل دلالة النص؛ كما أن انصـراف مقتضـى الحسال في البلاغـة إلى

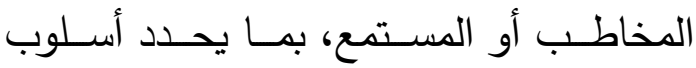
المـكلم أو النص - ينـاظر إصـرار الأسـلوبية

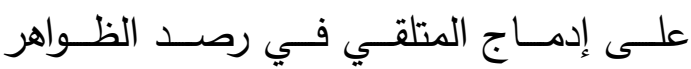

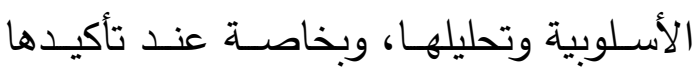
على أن الأسـلوب هو نتيجـة اختيار المؤلف واسـترجاع المتلقـي؛ ومـن ذلـك أيضــاً مفهـوم العـدول فـي البلاغــة الـذي يــوازي مفهـوم

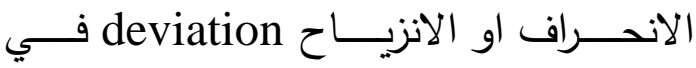

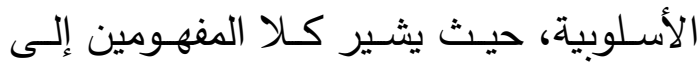
مستوى تعبيري يعد خروجاً عن النظام اللغوي العـام، وانتهاكاً لـه، مـن أجل غيلـ غايـات جماليـة تتجاوز البعد الإخباري أو التوصيلي. هذا إلى ويدعو إلى الإفـادة مـن التجربـة الأوربيـة في تعاملها مـع بلاغتها القديمة والوسيطة، تمهيداً للانتقال الطبيعي إلى الدرس الحديث: أحمد درويش، النص البلاغي في التراث العربـي والأوربي. ص. 179 وما بعدها.

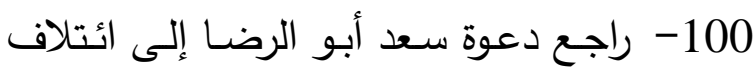

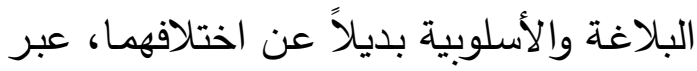
اعتبـار البلاغـة بفنونها وسـائل تعبيريـة يمكن توظيفهـا لتحقيـق الدراسـة الأســلوبية وإقامــة التحليل البلاغي الكاشف، مع الاستعانة بالبعد اللساني، بما يمكن أن يؤدي إلى تجاوز كثير مدـا وصـفت بـه البلاغـة مسن طـابع تفتيتهي وتجزيـيء للظـاهرة، ومـن ثم تحقـق فاعليتهـا التحليلية في النظرة الكلية للنص ومستويات

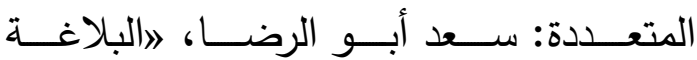

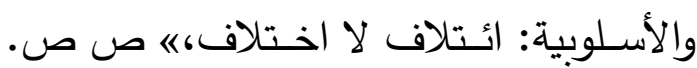
693 694

101- محم عبد المطلب، البلاغة العربية: قراءة أخـرى. (الثــركة المصـريـة العالنيـة للنشـر : لونجمـان، القـاهرة، ط1؛ 1997م)، ص ص. .9 102- تمـام حسـان، 》المصطلح البلاغى القديم فى ضـوي البلاغـة الحديثة،هـ مجلـة فصـول. (الهيئة المصـرية العامـة للكتاب، القاهرة، مـج

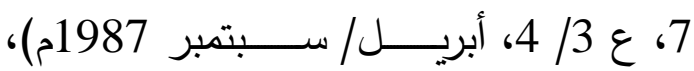
ص.28. ويشـير تمـام حسـان كذلك إلـى أن أن 
1993م)، ص. 11 ومابعدها.

103- عبــد القــادر المهيـري، التقـديم كتـاب:

البلاغة العامـة،ه حوليات الجامعة التونسية.

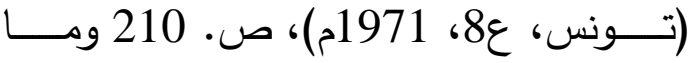

بعدها، وبخاصة ص. 221.

104- كان للمراجعات والانتقادات التي وجهت

إلـى التحليـل الأسـلوبي وفرضـياته، لا سـيما

مراجعـة السـتانلي فش《ش، دورهـا في تطـور

الاسـلوبيات، وتوسـيع مجالهـا، بمـا يمكن أن

يشكل نهاية للأسلوبية، أو إعلاناً عن أسلوبية

جديــدة، بــالتخلي عــن أبــرز فرضـــاتها

وإجراءاتها. وفي السياق نفسـ، ولكن بطريقة

مختلفـة، يـرى منــر عياشـي أن الأسـلوبية

مضطرة أن تدخل مرحلة جديدة من تطورهـا،

يمكن تسميتها مرحلة ما بعد الأسلوبية، تكون

من وجهة نظره أسلوبيات للخطاب أو النص.

وهو ما يتقق معه مازن الوعر، عندما يرى أن

تحليـل الخطـاب discourse analysis،

والـذي هـو فـرع مـن اللسـانيات الاجتماعيـة

sociolinguistics

الأسلوبيات، ليكون البديل الأكثر علمية منها.

انظر في ذلك:

ستانلي فش، هل يوجد نص في هذا الفصل؟

ص ص. 349، 350، 370 .

-منـذر عياشـي، الأسـلوبية وتحليـل الخطــاب.

(مركز الإنمـاء الحضـاري، حلب، 2002م)،

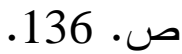

-مـازن الوعر، 》الاتجاهـات اللسـانية ودورهـا في

الدراسـات الأسـلوبية،هـ مجلــة عـالم الفكـر .
جانب العديد من التوازيات الأخرى منها: نظرة كـلـل مــن "جــان كــوهن و "اعبـــالقاهر الجرجــاني" للثــعر ، وتصـــور كـلـ مــن

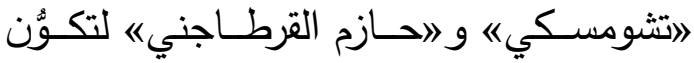
الأسلوب، وكذلك فكرة النظم عند عبدالقاهر ومحور التأليف عند 》ياكوبسونه من ناحية، ووحـدة الــدال والمــدلول مــن وجهــة نظــر الأسلوبية اللسانية من ناحية أخرى. واجع فيما

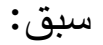
-تمـام حسـان، 》المصــلح البلاغي القـديم في ضـوء البلاغـة الحديثة،ه ص. 22 ومابعدها. وكذلك: الأصــول - دراســة إبسـتيمولوجية للفكر اللغوي عند العرب: النحو، فقـه اللغة، البلاغة. (عالم الكتب، القاهرة، 2000م)، ص ص. -بدوي طبانـة، البيـان العربـي. (مكتبـة الأنجلـو المصـــرية، القــــاهرة، ط6؛ 1976م)، ص. .413 -شكري عيـاد، مدخل إلى علم الأسـلوب. ص. 43 ومابعدها.

- محمد عبد المطلب، البلاغـة والأسـلوبية. (الهيئة المصـرية العامـة للكتـاب، القـاهرة، 1984م)، ص. 4. 4، 6، 7، -فتح الله أحمد سليمان، الأسلوبية: مدخل نظري ودراسة تطبيقية. (الدار الفنية للنشر والتوزيع، القاهرة 1991م)، ص ص. 28 - 30. -صلاح فضل، علم الأسلوب. ص. 31. -أحمد درويش، ا(مقدمة كتاب: بنـاء لغة الثـعر لجون كـوين، (دار المعارف، القاهرة، ط3؛ 
ومعارف أخري، والانتقال بالتالي من تحليل الأســاليب إلـى تفسـير النصــوص الأدبيـة

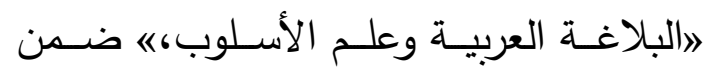

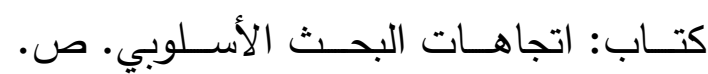
212. ومما يؤكد هذا التطلع أو الفهم إثـارة المؤلف إلى تحول ريفاتير عن علم الأسلوب النيا

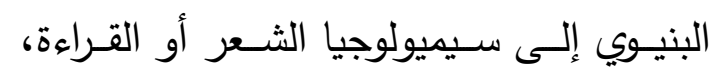

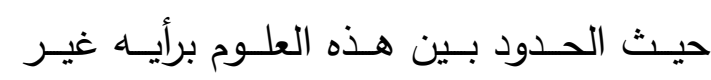

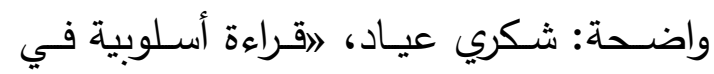
كتاب سييويه،؛ ضـن كتـاب: قراءة جديدة

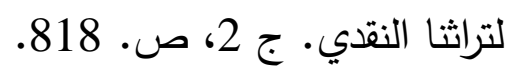

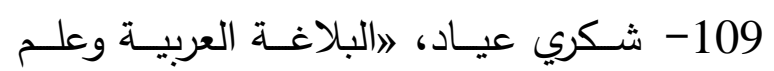

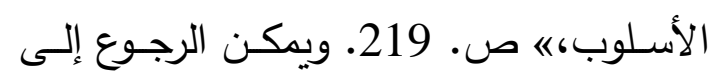
وظيفة علم الأدب/ البلاغة عند السكاكي في:

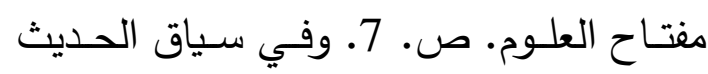
عن تلك الوظيفـة يرى شكري عياد أنـه لولا

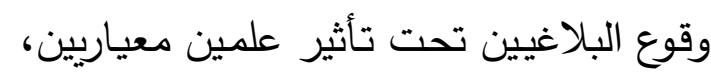

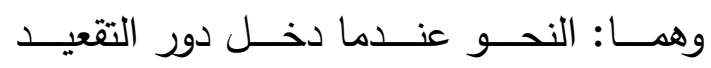

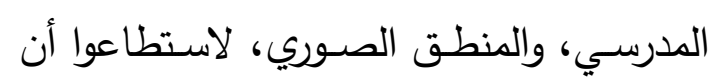

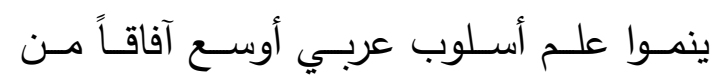
البلاغة الحالية: شكري عياد، اقراءة أسلوبية في كتاب سيبويه،، ضمن كتاب: قراءة جديدة

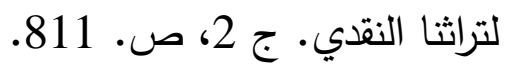

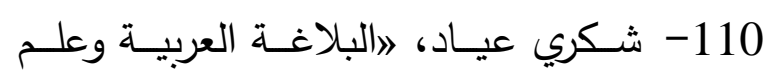

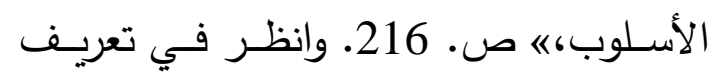
السكاكي للبلاغة: مفتاح العلوم. ص.

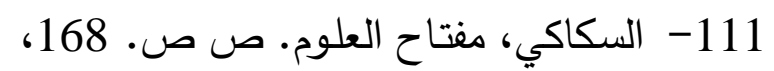
.169 112- عبد القـاهر الجرجاني (ت 471 هـ)،
(المجلـس الـوطني للثقافـة والفنـون والآداب،

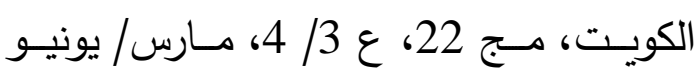
1994م)، ص. 170 وما بعدها.

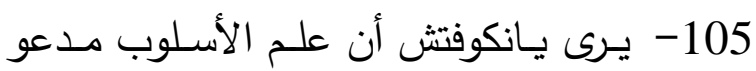

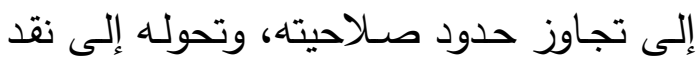
ينظر في علاقـة العلامـة الاستطيقية بـالقيم وبتجـارب المتلقي في الحيـاة والفن: مـيلان يانكوفتش، 》الأسلوب الفردي ومشكلة المعنى في العمل الأدبي،ه ترجمة: شكري محمد عياد.

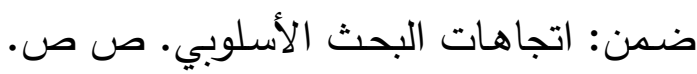
206 206 106- يشـير صـلاح فضـل إلى توجـه البلاغـة

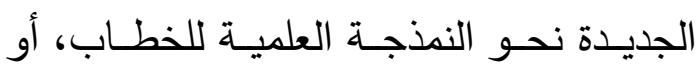
التجريـد الذي ينبني على التجريب، والخبرة

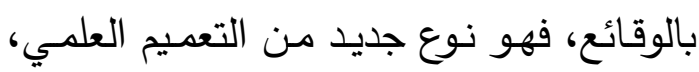
يختلف في طبيعته عن التعميمات المنطقية القبلية، والأحكام القيمية المسبقة. إنها التعميم النسبي الذي تخضع له جميع العلوم الطبيعية والإنسانية، عندما تتنظم في أنساق معرفية،

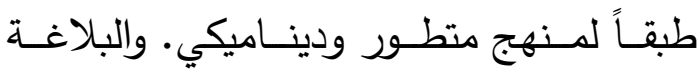
الجديدة، التي تدخل فيما يسمى الآن بحركـة

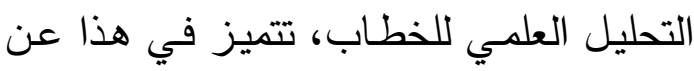

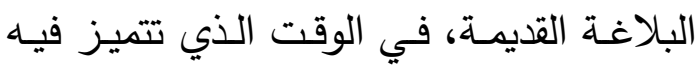

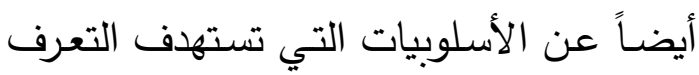

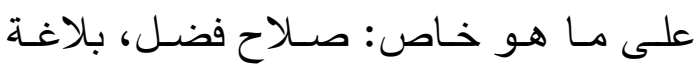
الخطاب. ص ص. 179، 183. 107- محمد مشبال، البلاغة والأدب. ص. ص. 58.

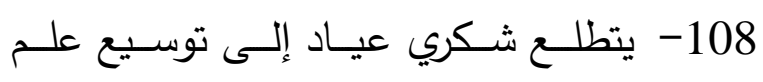

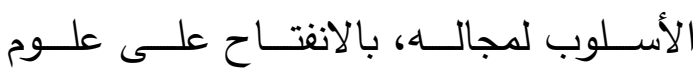




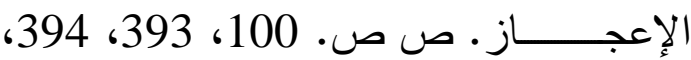
.(430، 429

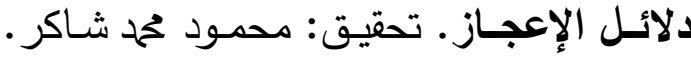
115- ابن يعقوب المغربي (1128هـ)، مواهب الفتـاح فـى شـرح تلخـيص المفتـاح. تحقيق: خليـل إبـراهيم خليـل. (دار الكتـب العلميـة، بيروت، ط1؛ 2003م)، مج1، ص138. 116- يعرف السكاكي غلم البيان بقوله: "وأمـا علم البيان: فهو معرفة إيراد المعنى الواحد في

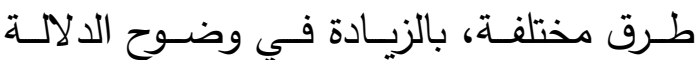
عليه، وبالنقصـان ليحترز بالوقوف على ذلك عن الخطأ في مطابقة الكلام لتمام المراد منـه ...". مفتاح العلوم. ص. 162.

117- السكاكي، مفتاح العلوم. ص. 161. 118- انظر تساؤل شكري عياد أو تشككه في الرابطة التي تجمع بين علمي المعاني والبيان بوصفهما علمين بلاغيين: 》البلاغـة العربيـة وعلم الأسلوب، « ص. 216.

119- السكاكي، مفتاح العلوم. ص. 432. 120- السكاكي، مفتاح العلوم. ص. 162.

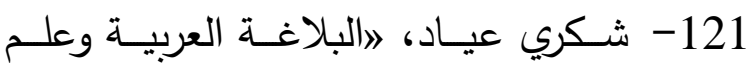
الأسلوب، « ص. 223.

122- السكاكي، مفتاح العلوم. ص. 423. 123- راجهع عرض 》أ. ربـوله لمـا يـراه أصـولًا

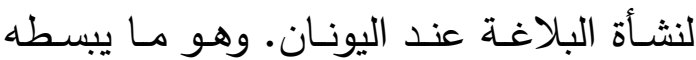
بارت بلغة مختلفة في قراءته للبلاغة القديمة: -أوليفيي ربول، 》أصسول البلاغـة عند اليونـان . القسـم الأول،ه ترجمـة: عحمد النـويري. مجلــة علامـات فـي النقـــ الأدبـي. (النـادي الأدبـي الثتــافي، جــدة، مـــج 4، ج 14، ديســمبر

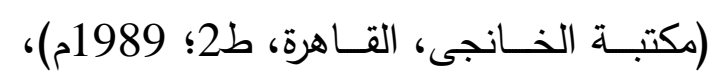
ص. 113- عبد القـاهر الجرجـاني، دلائل الإعجـاز . ص ص. 51، 87. ويقــــل القزوينــي: ".. تطبيق الكلام على مقتضـى الحال هو الذى يسميه الثيخ عبد القاهر بالنظم، حيث يقول: النظم تآخى معانى النحو فيما بين الكلم، على حسـب الأغـراض التـى يصــاغ لهـا الكـلام.": الخطيب القزويني (ت 739هـ)، الإيضـاح فى علـوم البلاغــة. شـرح وتعليـق وتتقـيح: محمد عبدالمنعم خفاجى. (دار الجيل، بيروت، طب؛ 1993م)، مج1، ج 1، ص. ص. 44. 114- فى الوقت الذى ينطلق فيـه عبد القـاهر من أن النظم هو أصل لكل كلام، فإنـه يقف متردداً حول اعتبار المجاز من حسن النظم. فحيناً يفرق بينهمـا بـأن يقسم الكـلام قسمين: قسـم ترجـع فيـه المزيـة والحسـن إلـى الـنظم، وقسم آخر يرجع فضله إلى كونه مجازاً وعدولاً باللفظ عن الظاهر، فلمجاز حسنه الذى يعود إلـى اللفـظ، وهـــ مسـتقل ومغــاير للحسـن المتحقق بالنظم. وحيناً آخر يتخلى عبد القاهر ـ فـى بعض نصوصسه . عـن تردده، وعن المحافظــة على إقامـة التعـارض بـين الـنظم والمجاز، عندما يجعل مفهوم النظم يستوعب فى داخله المجاز ، كأن يرى مختلف ضروب

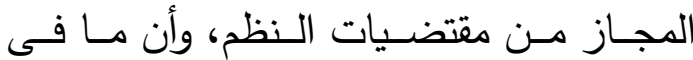
المجاز من معان لا يمكن بيانه إلا بعد العلم بالنظم والوقوف على حقيقته (انظر : دلائل 
126- جابر عصفور ، 》بلاغة المقدوعين، ألف • مجلة البلاغة المقارنة. (الجامعة الأمريكية، القاهرة، ع12، 1992م)، ص. 8.

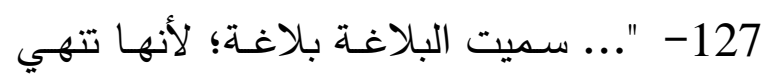

المعنـى إلـى قلـب السـامع فيفهـــه .../... البلاغة: كل ما تبَلَّغ به المعنى قلب السامع، فتمكنه في نفسه، كتمكنه في نفسك، مع صورة مقبولـة ومعـرض حسـن." (أبـوهلال العسكري

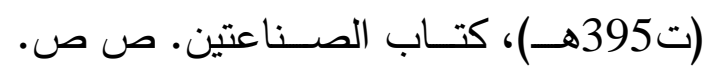
12، 16) "... البلاغــــة بلـــوغ المعنــى ... التقرب من البغية ... إهداء المعنى إلى القلب

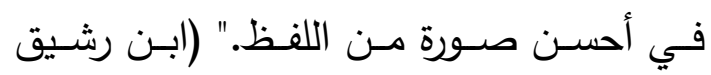
(ت 456هـ)، العـــدة فـي محاسـن الثـعر وآدابـه ونقده. تحقيق: محهد محيي الدين عبد الحميد. (دار الجيل، بيروت، ط5؛ 1981م)، ج 1، ص.246). "... البلاغـة ... الوصـول إلـى المعـاني البديعيـة بالألفـاظ الحسـنة .... وصـول الإنسـان بعبارتــه كنـه مـا فـى قلبـه."

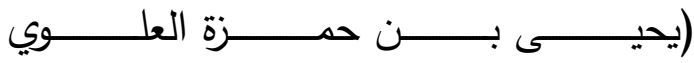
(ت 749هـ)، الطراز المتضمن لأسرار البلاغة وعلوم حقائق الإعجاز . قدمه: حمح عبد السلام

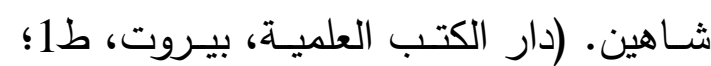

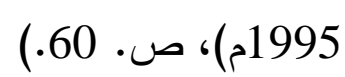
128- حمـادي صـمود، في نظربـة الأدب عنــ العـرب. (النـادي الأدبسي الثقافي، جدة، ط1؛ 1990م)، ص ص. (19 4)، 42. 129- يتحدث Sempson عما لحق الأسلوبيات من تطور في الاتجاه بدراسـة الوقائع اللغويـة،

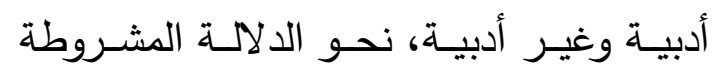

$$
\text { 1994م)، ص. } 149 \text { وما بعدها. }
$$

-رولان بارت، قراءة جديدة للبلاغة القديمة. ص. 15 وما بعدها.

124- الحسين بنو هاشم، نظربـة الحجـاج عنــ شـاييم بيرلمـان. (دار الكتاب الجديد المتحدة، بيروت - بنغازي، ط1؛ 2014م)، ص. 12. وحـول تـداخل البعدين: الإقنـاعي والتخييلي داخل الخطاب، وتبعية أحدهما للآخر بحسب الجنس التعبيري: الشعر أو الخطابة، وكيف ونف أن الأقاويـل المقنعـة الواقعـة فى الثـعر ، على النى نحو ما يشير حازم القرطاجنى ينبغي أن تكون تابعة لأقاويل مخيلة، مؤكدة لمعانيها، مناسبة لها فيما قصد بها مـن الأغراض، وأن تكون هونه المخيلة هي العمدة؛ حول ذلك انظر : -حـازم القرطـاجني، منهـــاج البلغــاء. ص. 62 ومابعدها.

-خحمد العمـرى، البلاغــة الجديــدة بـين التخيـلـ والتـــداول. (أفريقيـا الشـرق، الـدار البيضــاء، 2005م)، ص ص. 11 - 34، وبخاصـــــــة

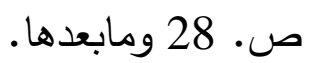
125- ينظر شكري عياد إلى مفهوم 》الاحتراز عـن الخطـأ فـي أداء المعنـى المـراده مـنـ وجهين: يرجع أحدهما إلى المستوى البلاغي، بينمـا يرجع الثاني إلى الجانب التحقيقي في الإبلاغ، مهما يكن مستوى الكلام من البلاغة بمعناهـــا الفنـي، أي يرجـــع إلـــى الاختيــار 》الناجع《 للتعبير المطابق 》للاعتبار 《 الذي في نفـس المـتكلم: شـكري عيـاد، 》البلاغــة العربية وعلم الأسلوب،《ي ص. 222. 
ص ص. 176، 207.

131- في سياق حديث فان دايك عن علم النص

بوصفه ممثلاً عصرياً للبلاغة القديمة، يشير

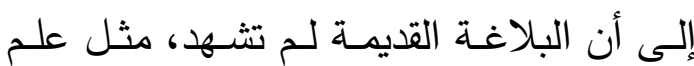

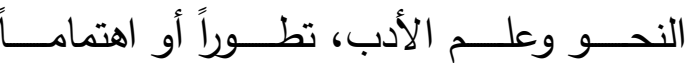

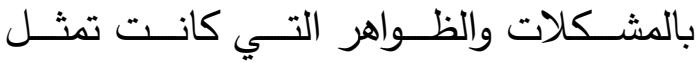
موضـوعاً لها، وإن عـاودت بعض انشـالات البلاغــة القديمـة مثـلـ الخاصــية المعياريــة للأقوال الظهور ضمن التطورات الحديثة لعلم اللغة وعلم الأسلوب: تون أ. فان دايك، علم لمات النص: مدخل متداخل الاختصاصات. ترجمة: سـعيد بحيـري. (دار القـاهرة، القـاهرة، طـ 2؛ 2005م)، ص ص. 22، 23. ويؤكد ريفاتير

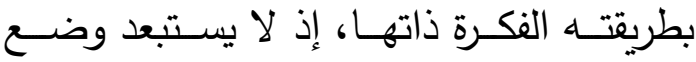
نمـوذج عام للأسلوب تكون علاقـة الأشكال الفردية بالأسلوب كعلاقة الأقوال باللغة، تمدنا دراستها بالمعطيات الأساسية لعلم متكامل في المستقبل. وإلى أن يتم ذلك فهو معنيّ بقيمة

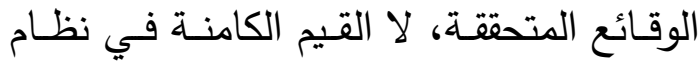

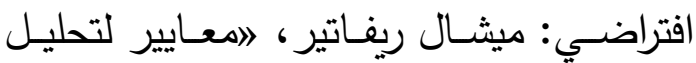
الأسـلوب،ه ترجمـة: شكرى عيـاد. ضـــن اتجاهات البحث الأسلوبي. ص. 126. 132- شكري عياد، 》قراءة أسلوبية في كتاب الهناب سييويه،ه ضـن كتاب: قراءة جديدة لتراثنا النقدي. ج 2، ص. 812. وانظـر تحليلات المؤلف لمقولـة سيبويه 》اتمثيل وإن لم يُنكلم بهاه ومظاهرها المختلفة: اقراءة أسلوبية في كتاب سييويه،؛ ص ص. 805-812؛ اللغة والإبداع. ص ص. 103-106.
بالسياق، فإنتاج الأقوال/ النصوص إنما يتم في زمان ومكان محددين، وفي سياق ثقافي gمعرفي. وهذه الحدود خارج اللسانية - extra linguistic التى "يدل" بها النص: Paul Sempson (2004), Stylistics - A Resourse Book for Students. (Routledge University Press, London - New York, $\left.1^{\text {st }} .2004\right)$, p. 3.

130- على الرغم من أن شكري عياد يقر بأن السكاكي يجعل الدلالات التي يختص بها علم

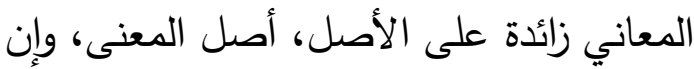
يقيت مرتبطة، كما في النحو، بتراكيب الكلام،

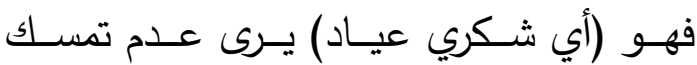
السكاكي واستقراره على هذا الفهم، بما يمكِّن

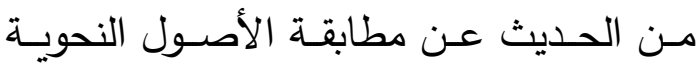

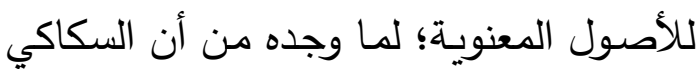

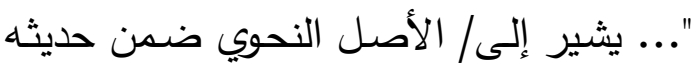

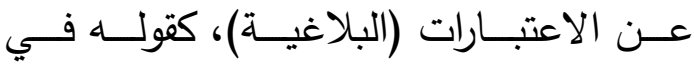
اعتبارات ذكر المسند إليه: 》أو لأن الأصل

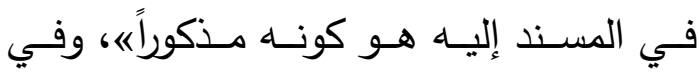

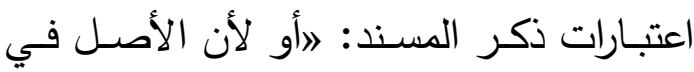

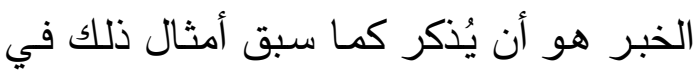

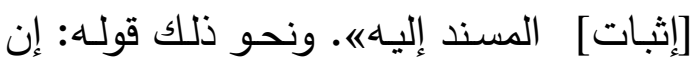
تقديم بعض أجزاء الجملـة للاهتمـام بشـأنه

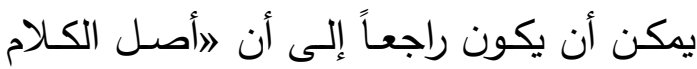

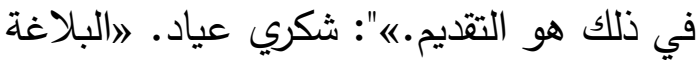

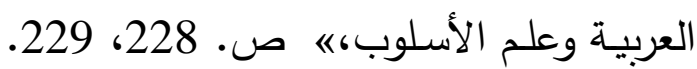
وانظر نص كلام السكاكي في: مفتاح العلوم. 
يمكن أن ينطلق منـه الـوعي الأسـلوبي للغــة الأدبية. وإن كان الأمر يتطلب عند التأسيس أو الانطـلاق أن يوضــع في الاعتبـار نقطـة التباعد أو التباين الثديد بين البلاغـة القديمـة

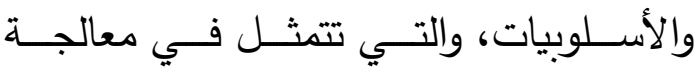
الأسـلوبيات للتـوع غير المحدود في أجنـاس النصـوص الأدبيـة الحديثـة وتطـور أشـالها، والتي لا عهد للبلاغة بها، وإن لم يكن هنالك مـا يمنــع مـن الحـوار مــع البلاغــة القديمــة

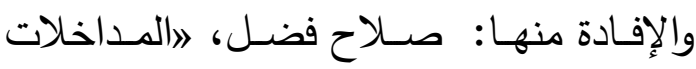
على بحـث الـدكتور سـعد مصـلوح،ه ضـمن كتاب: قراءة جديدة لتراثنا النقدي. ج 2، ص.

139- يـرى شـكري عيـاد أن النقــاد العـرب -

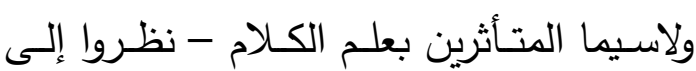
الأسـلوب نظـرة تقـرب ممــا يُسـمى في النقـــ

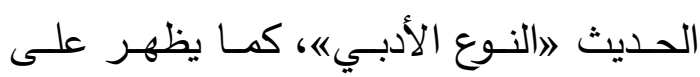
سبيل المثال عند الباقلاني (ت 403هـ) وابن قتيبة (ت 276هـ) في حديثهم عن الأسـاليب، دون أن نظفر ببحث العلاقة بين النوع الأدبي وطرق الصياغة، اللهم إلا لمحات خاطفة عند الجـاحظ (ت 255هـ)، وشـيء مـن التقصـيل عند ابـن خلـدون (ت 808هـ)، الأمسر جعل هل كلمـة الأسـلوب عنــ البلاغيـين العـرب عامـة مبهمة المعنى، تشير إلى النوع، كما تشير إلى الموضوع/ الغرض/ المعنى، أو طرق التعبير/ الصـياغة. وقد انتهى الحسال بالأسـلوب إلى لى البحث عن مكان له بجانب علم البلاغة، دون أن يتمكن من تحديد أقسامه وأنواعه كما اتفق لبقاب
133- شـكري عيـاد، 》البلاغــة العربيــة وعلـم الأسلوب، س ص. 229. 134- شـكري عيـاد، اللغــة والإبـداع. ص. 6. ويشير المؤلف إلى أن مـا عليه المـادة اللغويـة

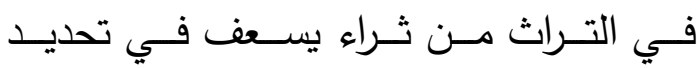
الخصـائص الأسـلوبية للخطـاب، في جميـع مســتويات الاســتعمال: المفـردات، الصــيخ الصرفية كالجموع، الأصوات، التراكيب. وهو مـا يدعو إلى استغلال هذا الرصيد الضـخم، مــع الوقـوف علــى تفــاعلات المســتويات المختلفـة، ومـا تنتجـهـ مـن قيم تعبيريـة: اللغــة والإبداع. ص ص. 57، 68. 135- ســـد مصـلوح، 》امشـكل العلاقــة بـين البلاغة العربية والأسلوبيات اللسانية،ه ضمن كتاب: قراءة جديدة لتراثنا النقدي. ج 2، ص. .862

136- يـرفض صــلاح فضـل محاولـة الـربط أو المقاربــة بـين البلاغـة العربيـة وعلـم أسـلوب اللغة؛ استتاداً إلى المباينة المنهجية والتاريخية بين البلاغـة القديمـة والأسلوبيات، مستحضـراً مبادئ الأسلوبيات وفرضياتها وتطلعاتها، بدلاًا من النظر إلى واقع علم أسلوب اللغة الذي لـ يحقق نتائج مرضية، خاصـة في ظل ارتباطه ببدايات الدرس الأسلوبي: صـلاح فضل، علم الأسلوب. ص ص. 139، 140.

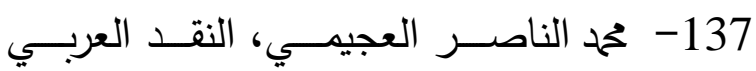
الحديث ومدارس النقد الغربية. ص. 457. 138- يرى صـلاح فضـل أنـه يمكن بنـاء قاعدة الوعي الأسلوبي لمستوى اللغة العام كتأسيس 
شكري عياد الشخصية، فالأسلوب عنده هو سر العمل الأدبي، وهو مرادف النوع الأدبي: خيري دومـه، 》النوع والأسلوب: قراءة في نقد شكري عياد،ه مجلـة فيلادلفيا الثقافيـة. ص ص. 105-107 - 105.

140- راجع تحليل شكري عياد لميمية المتنبي في وصف الحمى: اللغـة والإبـداع. ص ص. .140-131
لعلم البلاغة، فلم يبق أمامـه إلا أن يحيل إلى الخبـرة المكتسـبة مـن كثرة الأمثلـة، ومسن ثم عجز عن أن يصير علماً. هذا في مقابل مـا يبديــه شـكري عيـاد مــن تصــور إزاء عــم الأسلوب الذي يتناول الظاهرة الأسلوبية بحثاً في قـوانين التفرد والخصوصـية، إلى جانـب تحليل النص لاكتثاف نظامه الخاص: شكري عيــاد، اللغـــة والإبــــاع. ص ص. 18، 22، 60، 61. ويشـير خيـري دومــه إلـى أن هـــه العلاقة بين الأسلوب والنوع الأدبي تمثل قناعة 